\title{
An economic examination of state legal regimes within the U.S. system of federalism
}

John A. Dove

West Virginia University

Follow this and additional works at: https://researchrepository.wvu.edu/etd

\section{Recommended Citation}

Dove, John A., "An economic examination of state legal regimes within the U.S. system of federalism" (2012). Graduate Theses, Dissertations, and Problem Reports. 4848.

https://researchrepository.wvu.edu/etd/4848

This Dissertation is protected by copyright and/or related rights. It has been brought to you by the The Research Repository @ WVU with permission from the rights-holder(s). You are free to use this Dissertation in any way that is permitted by the copyright and related rights legislation that applies to your use. For other uses you must obtain permission from the rights-holder(s) directly, unless additional rights are indicated by a Creative Commons license in the record and/ or on the work itself. This Dissertation has been accepted for inclusion in WVU Graduate Theses, Dissertations, and Problem Reports collection by an authorized administrator of The Research Repository @ WVU.

For more information, please contact researchrepository@mail.wvu.edu. 


\title{
AN ECONOMIC EXAMINATION OF STATE LEGAL REGIMES WITHIN THE U.S. SYSTEM OF FEDERALISM
}

\author{
JOHN A. DOVE \\ Dissertation submitted to the \\ College of Business and Economics \\ at West Virginia University \\ in partial fulfillment of the requirements \\ for the degree of
}
Doctor of Philosophy
in
Economics

\begin{abstract}
Andrew T. Young, Ph.D., Chair
Christopher J. Coyne, Ph.D.

Roger Congleton, Ph.D.

Santiago M. Pinto, Ph.D.

Russell S. Sobel, Ph.D.

Department of Economics
Morgantown, West Virginia
2012

Keywords: Antitrust; Default; Fiscal Federalism; Intergovernmental Competition; Legal

Federalism; Sovereign Debt 


\title{
Abstract \\ AN ECONOMIC EXAMINATION OF STATE LEGAL REGIMES WITHIN THE U.S. SYSTEM OF FEDERALISM
}

\begin{abstract}
John A. Dove
This dissertation is a collection of essays, each of which studies certain aspects of and differences between state legal frameworks within the U.S. Specifically, I analyze how even marginal differences between laws across the states can lead to radically different outcomes and incentives for both public and private actors. The first chapter explores state antitrust enforcement, as carried out by each state's attorney general, to empirically test the potential policy business cycle that is created during elections for that office and for those sitting attorneys general that simultaneously pursue a gubernatorial position within their respective state. The second chapter applies Schumpeter's (1942) process of creative destruction in the light of its impact on legal formation and creation. In particular, this chapter explores how the process of entrepreneurial creative destruction creates a gap in existing law and legal precedent, which simultaneously sets in motion a process of legal creative destruction. In this framework, entrepreneurs, at the margin, will shed the legal risks they face by shifting their activities to those jurisdictions that will most predictably create new law or legal precedent to cope with the new entrepreneurial processes or discoveries. The third chapter explores the sovereign debt crisis that swept the U.S. between 1839 and 1842, the aftermath of which caused eight states and one territory to default on their debt obligations, five of them eventually repudiating all or part of those obligations. This chapter further empirically analyzes the post default period when many states passed constitutional constraints meant to prevent future state governments from pursuing similar behavior through time. I test whether financial markets considered those constitutional constraints to be both binding and credible. Overall, the results suggest that markets did in fact react positively to these constitutional constraints, which allowed state governments to reenter capital markets relatively rapidly and on relatively favorable terms, even after defaulting.
\end{abstract}




\section{Acknowledgements}

First I would like to thank my family for all of their support over the years. It took me some time before I found what it was that I wanted to do with my life. However, through all of the tough choices and all the years they have all stood by me and been there when I've needed their support.

I also owe a great deal of thanks to my fiancé Laura Stealey. She is a great intellectual and has always challenged me with thought provoking and lively discussion. Without that I wouldn't have anywhere close to the amount of intellectual ammunition that I have today. I also want to thank her for always being there to offer the "legal way of thinking" that has so perfectly complemented my "economic way of thinking" and as a result has helped to add so much to my own research.

In addition I owe a huge debt of gratitude to Dr. Russell Sobel, Dr. Christopher Coyne, and Dr. Andrew Young. They all spent painstaking amounts of time to help me through my graduate career and to ensure that this dissertation was finished on time and in the way that it has been. They have also been gracious enough to continue working with me and, as a result, we have all produced countless co-authored articles, which I hope to continue to do moving forward in life. Without their help over these past four years I would be nowhere close to the academic that I am today.

I would like to thank Dr. Santiago Pinto and Dr. Roger Congleton for both agreeing to act as the remaining members of my dissertation committee. Both of them provided me with countless feedback throughout the writing of my dissertation, which greatly helped to improve the work and get it to the point where it is today.

Finally, I would also like to thank Adam Pellillo and numerous participants at the Southern Economic Association and Association of Private Enterprises' annual meetings for extremely helpful feedback throughout the writing of my dissertation.

\section{Publication Information}

The third essay in this dissertation, "Credible Commitments and Constitutional Constraints: State Debt Repudiation and Default in Nineteenth Century America" was published in the March, 2012 issue of Constitutional Political Economy. This article is reprinted in this dissertation with the permission of the publisher, Springer Publishing (http://www.springerpub.com/). The article can be found at the following site:

http://www.springer.com/social+sciences/political+science/journal/10602 


\section{Table of Contents}

Acknowledgements ........................................................................................................... ii

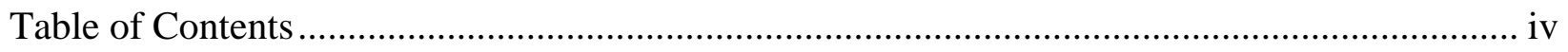

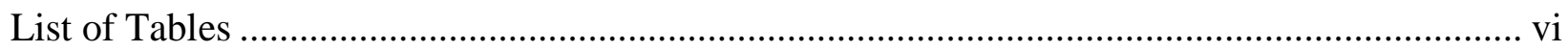

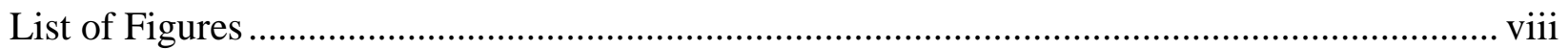

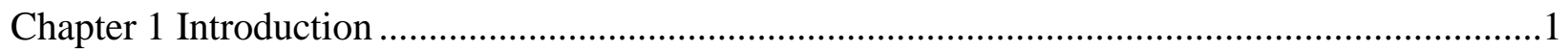

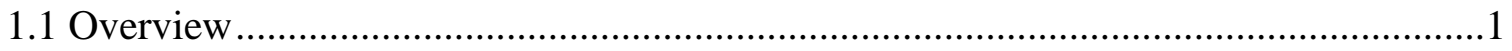

1.2 State Antitrust Enforcement...................................................................................

1.3 Legal Creative Destruction .............................................................................

1.4 Sovereign Debt and the Depression of 1839 .............................................................6

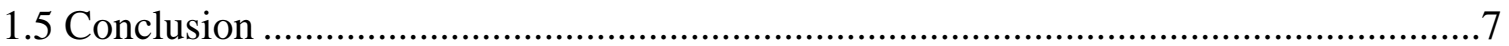

Chapter 2 Antitrust Enforcement by State Attorneys General: Institutional, Legal and Political

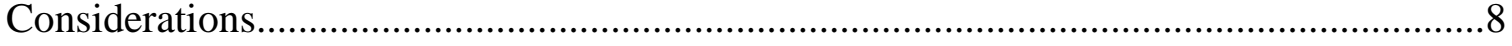

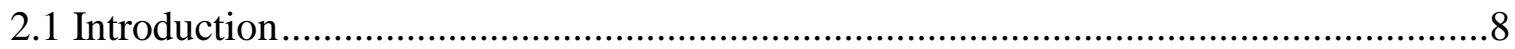

2.2 Brief History and Institutional Framework …………….........................................10

2.3 Data and Methodology ……………………………............................................15

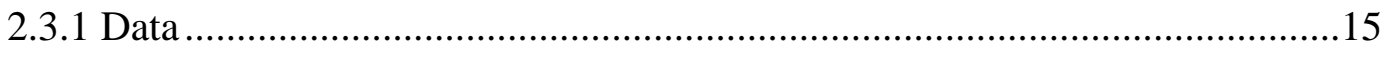

2.3.2 The Model ......................................................................................18

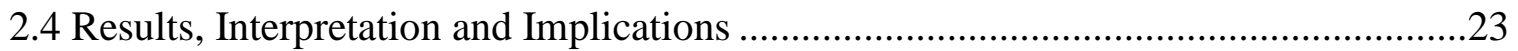

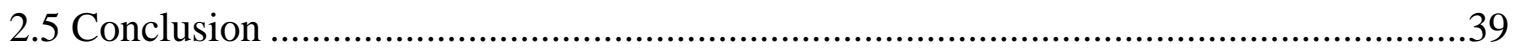

Chapter 3 Entrepreneurship, Innovation, and Legal Federalism: A Schumpeterian Approach.....41

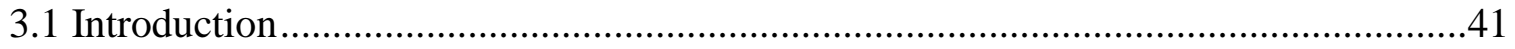

3.2 Entrepreneurship, Risk, Return and the Law .........................................................45

3.3 Entrepreneurial Innovation and the Evolution of Law ..............................................48

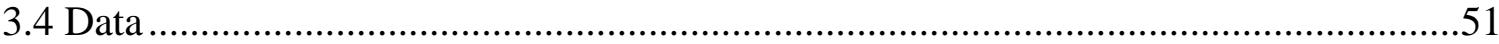

3.5 Legal Systems and the Allocation of Entrepreneurial Efforts - Baumol's Productive and Unproductive Entrepreneurship ...............................................................60

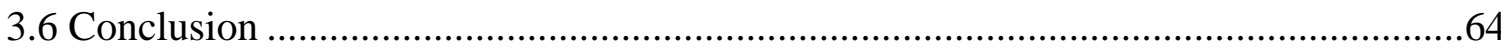

Chapter 4 Credible Commitments and Constitutional Constraints: State Debt Repudiation and Default in nineteenth Century America …………………................................................67 


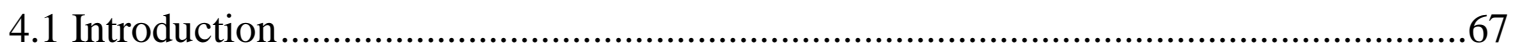

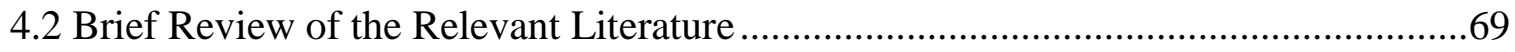

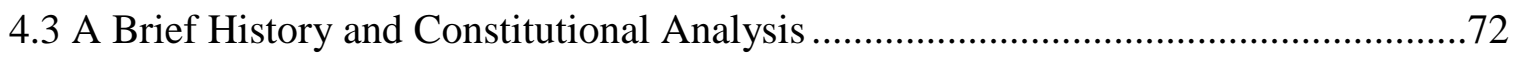

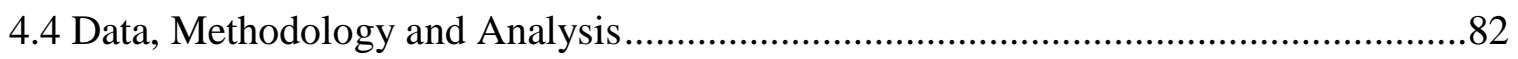

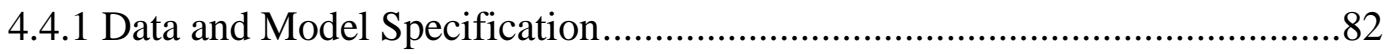

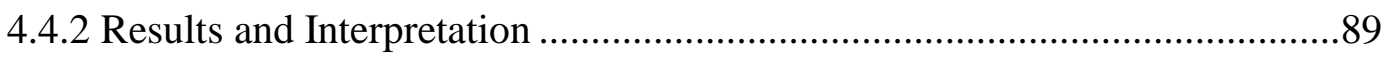

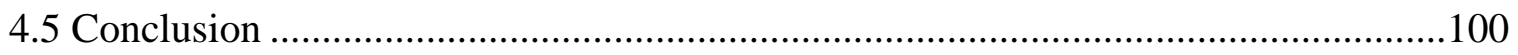

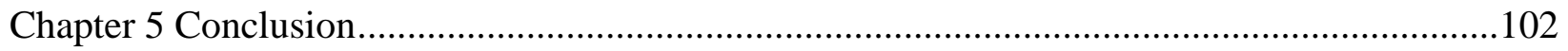

5.1 Concluding Remarks and Areas of Future Research .........................................102

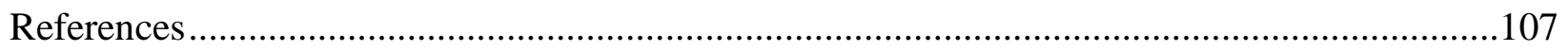




\section{List of Tables}

Table 2.1 Difference in Averages Results for AG and Gubernatorial Elections ..... .17

Table 2.2 Random and Fixed Effects Estimates for Single, In-State Antitrust Actions (Assuming Appointed AG Election $=1$ during each Respective State Gubernatorial Election) .........25

Table 2.3 Random and Fixed Effects Estimates for Multistate Participatory Antitrust Actions (Assuming Appointed AG Elections = 1 during each Respective State Gubernatorial Election)......

Table 2.4 Random and Fixed Effects Estimates for Multistate Lead Antitrust Actions (Assuming

Appointed AG Election = 1 during each Respective State Gubernatorial Election) .........30

Table 2.5 Random and Fixed Effects Interaction Estimates for Single, In-State Antitrust Actions

(Assuming Appointed AG Election = 1 during each Respective State Gubernatorial Election).....

Table 2.6 Random and Fixed Effects Interaction Estimates for Multistate Participatory Actions (Assuming Appointed AG Election = 1 during each Respective State Gubernatorial Election).

Table 2.7 Random and Fixed Effects Interaction Estimates for Multistate Lead Actions

(Assuming Appointed AG Election = 1 during each Respective State Gubernatorial Election).

Table 2.8 Random and Fixed Effects Estimates for Single, In-State Antitrust Actions (Assuming Appointed AG Election $=0$ for all elections)

Table 2.9 Random and Fixed Effects Estimates for Multistate Participatory Antitrust Actions

(Assuming Appointed AG Election $=0$ for all elections)

Table 2.10 Random and Fixed Effects Estimates for Multistate Lead Antitrust Actions

(Assuming Appointed AG Elections $=0$ for all elections).

Table 3.1 Number of Fortune 500 Companies Incorporated in States - Negative Binomial

Results .58

Table 3.2 Productive Entrepreneurship Measures by State, Regression Results. .64

Table 4.1 Constitutional changes imposed by state and year between 1840 and 1860

Table 4.2 Difference in Averages Results between those states that had imposed or had not imposed the listed constitutional amendments

Table 4.3 Pooled-OLS regression analysis using the average maturity date for each bond by state as the dependent variable

Table 4.4 Pooled-OLS interaction regression analysis using the average maturity date for each bond by state as the dependent variable. 
Table 4.5 Pooled-OLS regression analysis using the average interest rates paid on each bond by state as the dependent variable

Table 4.6 Pooled-OLS interaction regression analysis using the average interest rates paid on each bond by state as the dependent variable

Table 4.7 Pooled-OLS regression analysis using the average bond price for each state as the dependent variable

Table 4.8 Pooled-OLS interaction regression analysis using the average bond price for each state as the dependent variable .97

Table 4.9 Pooled-OLS regression analysis using the constitutional stringency index .98 


\section{List of Figures}

Figure 3.1 State Legal System Scores and State Income Growth...........................................52

Figure 3.2 State Legal System Ranking and State Income Level .........................................52

Figure 3.3 Correlation of Total Monetary Tort Losses and Overall Liability Index Score ...........53

Figure 3.4 Correlation of Tort Monetary Losses and Contract Litigation .................................54

Figure 3.5 Correlation of Tort Monetary Losses and Treatment of Tort and Rules of Discovery 54

Figure 3.6 Correlation of Tort Monetary Losses and Rules Regarding Scientific and Technical

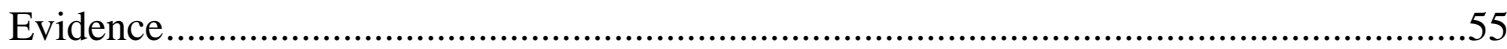

Figure 3.7 Correlation of Tort and Monetary Losses and Judges' Impartiality..........................55

Figure 3.8 Correlation of Tort Monetary Losses and Judges' Competence ................................56

Figure 3.9 Correlation of Tort Monetary Losses and Juries' Fairness .....................................56

Figure 3.10 Correlation of Tort Monetary Losses and Juries' Predictability .............................57

Figure 3.11 Comparison of Baumol Ratio against State Liability Index...................................62

Figure 3.12 Comparison of Large Establishment Birth Rate and State Liability Index ..............63

Figure 3.13 Comparison of Patents per Capita and State Liability Index ...............................63 


\section{Chapter 1}

\section{Introduction}

\subsection{Overview}

A well-documented literature has developed which analyzes the impact that legal institutions have on economic outcomes, and also the incentive effects that legal institutions play on economic actors (Priest 1977; Weingast 1995; Frye and Shleifer 1997; La Porta et al. 1999, 2004; Acemoglu et al. 2001, 2002; Glaeser and Shleifer 2002; Djankov et al. 2003; Acemoglu and Johnson 2005). Specifically, the rules of the game as they develop at both the constitutional and sub-constitutional level significantly affect the behavior of economic agents and outcomes. For instance, Hayek (1960) argues that predictable and easily discoverable laws allow individual actors to operate within a specific sphere with the knowledge that they will be free from the interference of others. Such an outcome, when laws and rules are consistently applied, allows individuals to make long-term plans and to better coordinate their behavior on a daily basis. Overall, this enhances the ability to make economic transactions and leads to greater growth and development. To the extent that the laws remain knowable and predictable, economic growth can occur.

Adding to this general literature, more narrow research has also focused on the competitive nature of interjurisdictional competition. The seminal work of Tiebout (1956) provides insight into how competition between governments, or fiscal federalism, leads to a more efficient provision of public goods, desired by those who are most willing to pay for them. On the flip side, for those jurisdictions that remain complacent or irresponsive to the desires of their constituents, mobility from one jurisdiction to another may force greater responsiveness and government compliance. 
A similar law literature has also emerged, which examines the impact that specific legal regimes and regulatory environments influence economic outcomes and incentives, and especially how interjurisdictional competition may influence these legal and regulatory environments (Easterbrook 1983; Romano 1985; Bratton and McCahery 1997; Posner 2004; Konisky and Woods 2009; Konisky 2010). This legal federalism literature has added greatly to the debate surrounding interjurisdictional competition. Therefore, this current dissertation attempts to examine not only how interjurisdictional competition within both the constitutional and sub-constitutional framework affects economic outcomes, it also considers how reforms to preexisting constitutional frameworks impacts government policy and behavior. These issues are examined from the U.S. system of federalism, and the fifty states that operate within it.

The first chapter of this dissertation analyzes the behavior of a specific officeholder within state governments in the United States: the office of state attorney general. As will be shown, differences in state laws and changes in federal legislation and regulatory oversight have led to changes in and differences between states in their enforcement of antitrust accusations.

The second chapter provides new insight into the Schumpeterian process of creative destruction. Specifically, it considers how entrepreneurial creative destruction leads to legal creative destruction. This plays out between horizontal competition between governments as, at the margin, entrepreneurship will migrate to those jurisdictions which provide the most predictable legal changes required by new entrepreneurial processes.

The final chapter of my dissertation considers the impact of legal change at the constitutional level of government and the impact that this can have on credibly committing a government to future, time consistent policy (Kydland and Prescott 1977; North and Weingast 1989; North 1991; Weingast 1993, 1995). This chapter analyzes the state debt crisis within the 
United States between 1839 and 1842 and the post-crisis constitutional changes that, as I suggest, were made as an attempt to reign in public debt and constitutionally constrain future governments from incurring such obligations again.

\subsection{State Antitrust Enforcement}

This chapter examines antitrust enforcement behavior by state attorneys general (AGs). A growing body of literature has developed which explores the influence that this office has within state politics (Posner 2004; Greve 2005; Gifford 2008; Provost 2003, 2006, 2010; Lemos 2011). Prior to the 1970s the office was generally considered with little regard in state politics. Most state AGs filled a part-time position and many states allowed their AGs to maintain a private practice while serving. However, by the 1980s this set of circumstances rapidly began to change. This became most evident in regard to antitrust enforcement involving both single and multistate actions.

Many of these changes were a result of both the Hart-Scott-Rodino Act (HSR) of 1976 as well as federal devolution during the 1980s under President Reagan. Specifically, the HSR provided $\$ 25$ million in seed money to state AGs in order to either create an antitrust division or increase enforcement by existing state antitrust divisions. Simultaneously, the HSR granted parens patriae authority to each state's respective AG in his or her capacity as the legal authority within the state. This parens patriae authority granted each state AG the ability to act on behalf of his or her constituents adversely affected by anticompetitive behavior by firms and to thus bring forth what were essentially class action lawsuits and simultaneously gain treble damages from successful suits. 
Through the 1980s with federal devolution and a general policy of non-enforcement of antitrust statutes, states through their respective AGs rapidly began to fill this void (Morris 1986; Zimmerman 1998; Waltenburg and Swinford 1999; Ray and Spill 2002). Further, the National Association of Attorneys General (NAAG) created a Multistate Antitrust Task Force which was charged with managing and coordinating increasingly numerous multistate antitrust actions. Thus, through the period state AGs were increasingly considered the de-facto third national enforcers of antitrust laws (Flexner and Racanelli 1993).

These events grew concurrently with the rapid increase in the overall significance of the office of state AG, resulting in many referring to state attorney general as standing for "almost governor" (Provost 2010). Increasingly, state AGs began using their office as a springboard into higher office, as of the 166 state AGs who served between 1980 and 1999, over 70 ran for either Governor or U.S. Congress, while 20 others were appointed to a U.S. lower court seat or high ranking federal agency position (Provost 2010). Overall, this has resulting in a large literature exploring the potential policy tools available to state AGs in their capacity as political actors.

Thus, this chapter contributes to this literature by empirically analyzing antitrust enforcement behavior by state AGs. Specifically, this chapter analyzes enforcement behavior in the presence of certain state and federally granted legal powers as well as the potential for antitrust enforcement to follow political business cycles for state AGs who are either running for their current office, or who ran for governor while still a sitting AG. Overall, I find strong evidence to suggest that both AG and gubernatorial elections as well as certain legal powers granted to AGs has a direct impact on not only the timing of an antitrust action, but also on the type of action an AG pursues. 


\subsection{Legal Creative Destruction}

The next chapter of my dissertation, co-authored with Russell Sobel, analyzes the impact that entrepreneurship may have on molding varying legal regimes at the state level. More precisely, this chapter suggests a slightly different twist on the process of Schumpeterian creative destruction. Schumpeter (1942) suggests that entrepreneurship necessarily leads to a process of creative destruction, whereby new technologies and innovations that enter the marketplace necessarily replace and make obsolete older technologies. Overall, these new processes improve overall economic wellbeing and welfare.

Along these lines, we suggest that this entrepreneurial creative destruction simultaneously leads to legal creative destruction. In other words, as new entrepreneurial processes emerge it makes obsolete older laws and legal precedent that built up around those laws regarding the entrepreneurial processes made obsolete. Thus, entrepreneurial creative destruction requires new laws and legal precedent to emerge in order to deal with these issues. However, it is not just the emergence of new law and legal precedent that matters, but the emergence of these laws and precedent to develop in the most predictable ways. Thus, we suggest that at the margin those entrepreneurs most in need of new laws and legal precedent due to their new innovations and technological advances will simultaneously locate in those jurisdictions that will provide those needed legal rules in the most predictable ways. Through this process entrepreneurs will be able to minimize the legal risks that they face as they innovate.

We further empirically analyze this with data made available from the Institute for Legal Reform's State Liabilities Index, which ranks the overall legal climate within the states. Overall, we find strong results that suggest that entrepreneurial activity, at least in regard to the place of 
incorporation, is driven by the overall predictability found within the legal atmosphere of a state and the potential legal changes that may occur either through new legislation or legal precedent.

\subsection{Sovereign Debt and the Depression of 1839}

While the first two chapters of my dissertation examines the incentive effects and economic outcomes that emerge within the constitutional rules of the game, my final chapter examines what happens when the very constitutional rules under which economic and political actors operate are altered. Specifically, this chapter looks at a unique episode in American history, when between 1839 and 1842 the country suffered through an acute economic depression. This episode was simultaneously a period of expanded government involvement in the construction of internal improvements and other industrial activity.

In order to finance all of these government funded projects, states incurred large amounts of debt. In doing so, state governments had hoped to be able to not only increase commerce and economic activity, but to simultaneously use the revenue received from the projects once completed to fully fund each respective government, and thus remove the need to directly tax citizens (McGrane 1933; Ratchford 1941; Wallis 2000). Although driven by the resounding success of the Erie Canal, most of the subsequent projects that resulted were found to be spectacular failures.

This became most apparent, first during the Panic of 1837 and followed by the depression of 1839 . By 1839 the country entered into an acute depression that lasted well into the 1840s. However, during this panic many of the internal improvement projects and other institutions funded by the various state governments either went belly-up or were forced to stop functioning. 
As a result, a multitude of state governments became severely financially constrained under the debt obligations that they had amassed through the 1830 s.

These constraints led first to Pennsylvania defaulting on its debt obligations, which was quickly followed by seven others. Of these states five outright repudiated all or part of their existing debt obligations, and thus exacerbated the problem. However, for many states soon after this fiasco they were able to reenter capital markets on relatively favorable terms.

Simultaneously, many of these same states passed constitutional amendments that strictly limited not only the amount and type of debt but also placed strict procedural safeguards on future state legislatures contemplating issuing more debt.

Given this, I hypothesize that these constitutional constraints were actually meant to both constrain and credibly commit future state governments to pursue time consistent policies regarding the ability to issue debt. Further, I suggest that it was these very constitutional constraints that were viewed by economic actors within bond markets to be credible, and were thus successful in convey the signal of credibility to bond markets. I empirically analyze this through a cross-sectional analysis of average state bond prices taken from the New York market in the aftermath of these constitutional changes. Overall, I find strong empirical evidence to support my hypothesis about the nature of those constitutional changes.

\subsection{Conclusion}

This section concludes my dissertation by summarizing the findings of the previous sections while rehashing the potential policy conclusions from each and finally providing future avenues for additional research. 


\section{Chapter 2}

\section{Antitrust Enforcement by State Attorneys General: Institutional, Legal and Political Considerations}

\subsection{Introduction}

The office of state attorney general (AG) is one of much significance. As the top legal officer and advisor both on behalf of a state, its citizens and the officials of that state, the role played by state AGs is vital. However, the importance of this office has only relatively recently come to the forefront of state affairs. In fact, before the early to mid 1970's the post was considered with little regard or esteem, but soon after this set of circumstances began to change. By this time many state AGs began increasing courtroom activism at both the state and federal levels and increasingly became much more prominent as forefront candidates for higher office. As a concrete example, of 166 state AGs who served between 1980 and 1999 over 70 ran for either Governor or U.S. Congress, while 20 others were appointed to a U.S. lower court seat or high ranking federal agency position (Provost 2010).

Most significant has been the increasing role that many AGs have played in enforcing antitrust violations both within and across state lines. Numerous studies suggest that state AGs have an automatic incentive to undertake large-scale antitrust litigation due to their ability to bring parens patriae suit (Posner 2004; Greve 2005; Gifford 2008). Literally meaning "parent of his country", parens patriae grants an AG the ability to bring what are effectively class action antitrust and consumer protection suit on behalf of his or her constituents under federal law. ${ }^{1}$

\footnotetext{
${ }^{1}$ This federal parens patriae authority was granted to state attorneys general under the HartScott-Rodino Act of 1976. The act further granted federal seed money for state AGs to create antitrust enforcement divisions within their offices.
} 
Although the various changes at the federal level have been considered, little attempt has been made to systematically understand how fundamental institutional and legal changes at the state level have affected AG behavior. Further, only recently has there been any formal work undertaken that analyzes the broader implications of state AG's enforcement decision (or lack thereof) as part of a coherent policymaking agenda (Provost 2003, 2006; Lemos forthcoming). Therefore, this current work is an attempt to fill this void and better explain and examine these issues in regard to antitrust enforcement decisions. In particular, this study provides a means by which to observe and determine the overall effect that the interactions between various statutorily and constitutionally provided changes: (1) term limit laws on the office, (2) partisanship as well as (3) state level parens patriae authority has had on both single, in-state and multi-state antitrust enforcement with data made available from the National Association of Attorneys General (NAAG) and various other sources between 1990-2008.

I further study state antitrust enforcement during both AG elections and gubernatorial elections in which a sitting AG pursued the governor's office as several studies have shown that many AGs have political ambitions and aspirations far beyond the office of state AG (Provost 2010; Lemos forthcoming). Antitrust enforcement provides a means by which AGs are not only able to acquire relatively low-cost exposure for themselves, but can also distribute monetary awards for successful antitrust suits either directly or indirectly back to constituents. Overall, my findings suggest that state antitrust enforcement is highly motivated and influenced by elections and electoral cycles not only for the office of attorney general but also by those AGs pursuing higher office. Thus, I find evidence that changing political incentives and legal constraints placed on this office affect the number, timing and type of antitrust actions pursued; where the type of action may be a single, in-state action or either the initiation or participation in a multi- 
state case. These results provide both policy implications for state level antitrust enforcement and potential for future research exploring state AG behavior in general as well as antitrust enforcement policy in particular.

The remainder of the paper is structured as follows: Section 2.2 gives a brief history of the office of state attorney general, the changing institutional structure that has occurred over time within it, how this has impacted the pursuit of state level antitrust violations, and why antitrust appears to be a preferred legal tool employed by state AGs. Section 2.3 describes the data and methodology employed to formally analyze the impact that electoral and institutional constraints have on state level antitrust enforcment. Section 2.4 provides the results and analysis, while Section 2.5 concludes.

\subsection{A Brief History and Institutional Framework}

The office of attorney general was a position carried over to the early American Colonies, preserved from the English legal system (Harmon 1991; Myers and Ross 2008). Prior to Independence, American Attorneys General were delegates of the English Attorney General, while after American Independence the office continued at the state level, with most states granting either constitutional or statutory requirements for the creation or maintenance of the office.

As the office stands today, there is great variation across states in regard to specific authority and powers. For example, forty-three state AGs are elected to their posts along partisan lines. Another five states (Alaska, Hawaii, New Hampshire, New Jersey, and Wyoming) grant the governor of each respective state the power to appoint. The remaining two states, Tennessee and Maine have two separate methods for selecting the attorney general: in 
Tennessee the state Supreme Court appoints the attorney general, while in Maine the office is filled by a secret ballot vote of the legislature. Further, in forty-nine states the office is considered a member of the executive branch, while in the fiftieth state, Tennessee, the office is considered a member of the judicial branch.

The office of attorney general has only recently come to prominence. Prior to the 1970 s most state AGs filled only a part time position, many of whom maintained private practices while serving. However, this rapidly began to change first with the passage of the Hart-ScottRodino Act in 1976 and Federal deregulation in the 1980s (Clayton 1994; Spill, Licari and Ray 2001; Ray and Spill 2002; Provost 2003, 2006). In general, this research points out that due to the decline throughout the 1980s of federal administrative and regulatory duties, an increasingly large gap in enforcement needed to be filled, and soon was by numerous state AG offices. This enlarged the exposure that state AGs faced especially within the U.S. Supreme Court, where they were able to coordinate their activities and, as some have suggested, act as political entrepreneurs in order to argue for and increasingly win significant changes in federal law (Morris 1986; Zimmerman 1998; Waltenburg and Swinford 1999; Ray and Spill 2002). These activities also helped to increase the role of the National Association of Attorneys General (NAAG), in its capacity to act as a federal activist and lobbyist (Clayton 1994; Zimmerman 1998; Greve 2005). Due to those changes evidence has increasingly suggested that the office of state attorney general has simply become a springboard into higher office, with many filling the post as a means to advance political careers, not necessarily the general welfare of constituents (Posner 2004; Provost 2010).

The most notable means through which change has come about has been in regard to antitrust enforcement. These circumstances have created a set of incentives whereby AGs may 
potentially use state antitrust and consumer protection statutes for both political gain and greater political exposure before constituents, employing these statutes against out-of-state interests, generally as a means to redistribute awards directly to voters (Waltenberg and Swinford 1999; Provost 2003; Posner, 2004; Greve 2005). This may be especially true for elected and more politically ambitious state AGs, which many jokingly say stands for "Almost Governor" (Provost 2010).

The relevant question then would be why it is that antitrust would be a tool potentially employed in order to achieve certain political ends. Unlike other potential outlets, decisions concerning antitrust enforcement have no executive or legislative oversight (as opposed to federal enforcement), thus leaving the sole discretion over enforcement and agenda control exclusively with the state AG (Lemos forthcoming). Further, prosecution of the majority of criminal activity falls almost exclusively to lower level district attorneys; the only situation under which state AGs generally represent the state in criminal proceedings outside of a direct request by a local prosecutor being on appeal by the defendant (Myers and Ross 2008). ${ }^{2}$ Thus, control over criminal prosecution by-and-large falls outside of the scope of a state AG.

Another important feature associated with antitrust enforcement revolves around the increasing trend of granting parens patriae authority for cases and the ability to distribute awards cy pres back to injured parties. Traditionally cy pres was applied by courts to trusts whose prespecified purpose was no longer relevant (Farmer 1999). Within this context, cy pres granted the court the ability to put such a trust to use in a manner that replicated as closely as possible the

\footnotetext{
${ }^{2}$ Exceptions where this has changed over time is in regard to state organized crime (RICO) enforcement statutes, some white collar crime and Medicaid/Medicare fraud. For example, since the adoption of Federal Racketeer Influenced Corrupt Organization Act (RICO) in 1970, 27 states have passed their own similar statutes, which generally fall under direct jurisdiction of those state's AGs.
} 
original intent of that trust. As granted to state AGs, application of cy pres provides sole discretion over the distribution of the proceeds from a successful settlement. For example, twenty-three AGs recently settled with eleven international vitamin producers over allegations of price fixing, resulting in a $\$ 225$ million settlement, half of which was distributed to indirect purchasers of those products, the other half distributed cy pres as each AG saw fit (Myers and Ross 2008).

Parens patriae is a doctrine which grants an AG the ability to pursue antitrust violations as a class action suit on behalf of the constituents of a state. Although the Hart-Scott-Rodino Act of 1976 granted all state AGs parens patriae authority to pursue antitrust violations under federal statute, the Supreme Court in a 1977 decision effectively overturned it. ${ }^{3}$ This gradually led states to grant parens patriae to AGs under state law, which statutorily granted recovery of damages from indirect purchasers. This practice was further validated by the Supreme Court in 1990, which held that all state statutes permitting the recovery of damages from indirect purchasers were not preempted by federal law (Ross and Myers 2008). ${ }^{4}$ Thus, by 1990 thirty-four states had statutorily granted parens patriae authority, while by 2008 forty-five states had granted the authority.

Along with these changes in the legal constraints faced by AGs, over this period there has been a massive change in the role of the National Association of Attorneys General (NAAG) regarding the coordination of antitrust policy and enforcement. In 1983 NAAG created the Multi-state Antitrust Task Force (MATF), which greatly reduced the cost of pursuing antitrust

\footnotetext{
${ }^{3}$ Illinois Brick Co. v. Illinois, 431 U.S. 720 (1977).

The Supreme Court ruled that indirect purchasers of goods and services were not eligible to collect damages using federal antitrust laws. Given that the majority of purchases made by both states and consumers are purchased indirectly, this ruling effectively denied parens patriae authority to state AGs in antitrust cases.

${ }^{4}$ California v. ARC America Corporation 490 U.S. 93, 101 (1989).
} 
violations by state AGs and increased both the ability to coordinate and streamline multi-state actions. Under the guidance of the MATF state AGs who initiate and take a leading role in pursuing multi-state antitrust actions are generally provided guidance and support from the agency. Further, once antitrust actions have been initiated and a case brought forth the MATF passes all of the relevant findings to all other state AGs, who then provide their own resources and man-power as well through the MATF if they so choose (Myers and Ross 2008). In this manner state antitrust activity has become much less costly and easier to pursue for many states, especially when pursuing actions against large-scale firms that an individual state would otherwise be unable to enforce due to a lack of funds or manpower.

It would appear that it is through the means outlined above that state AGs have been able to better coordinate and undertake antitrust actions over the recent past. Further, it seems that antitrust activity is one of the few areas of law enforcement that most state AGs may pursue at their sole discretion, making decisions of whether or not to enforce an antitrust statute or violation an extremely important policy tool available to state AGs.

Most important are the potential political ramifications associated with antitrust enforcement. As noted, 43 AGs are elected to their positions and the growing ambitions of many AGs have led some to nickname them "Almost Governor" (Provost 2010). In fact, between 1990-2008 there were 53 sitting AGs who simultaneously ran for the governor's office of their respective state. Given this, these potential considerations may play an important role in an AGs policy decisions, especially regarding antitrust enforcement. Further, a large body of literature examining the aspirations of other public officials suggests that incumbent politicians seeking higher office leads to much greater risk taking, political entrepreneurship and headline grabbing in general (Herrick and Moore 1993; Provost 2003; Lemos forthcoming). Indeed, antitrust 
enforcement would seem to be a potential outlet for more ambitious AGs to pursue in their run for an AG or gubernatorial position, given the discretion afforded an AG in enforcement as well as the distribution of awards from a successful case. Recent research also suggests that state AGs increasingly use their antitrust authority against out-of-state interests in order to directly benefit in-state firms and constituents (Zimmerman 1999; Posner 2004; DeBow 2004; Greve 2005).

Given this, antitrust enforcement may be viewed differently by both elected AGs as well as more politically motivated AGs who run for a gubernatorial seat within a state. Anecdotal evidence suggests that some AGs have indeed used their discretionary authority over antitrust enforcement for explicitly political motives. For example, when the former AG of South Carolina, Charles Condon, was campaigning for the gubernatorial seat in the state he distributed the award received from a successful multi-state antitrust case against Nine West (a footwear company) to fund anti-abortion crisis pregnancy centers throughout the state (Ieyoub and Eisenberg 2000).

Given all of this evidence there would seem to be an incentive to pursue antitrust violations potentially based more on political considerations rather than actual consumer welfare. The next section more formally examines these political ramifications and ambitions as well as how several of the legal and institutional constraints affect the timing and type of antitrust action pursued.

\subsection{Data and Methodology}

\subsubsection{Data}


In order to test the implications as laid above and to understand how the various incentives and constraints faced by state AGs have affected antitrust enforcement behavior I have compiled data from the National Association of Attorneys General Antitrust Litigation Database between 19902008. ${ }^{5}$ This source provides a comprehensive listing of all civil and criminal antitrust actions undertaken by the individual states. It further decomposes this data by year, the defendant and most importantly, whether the action was a single, in-state action or multi-state action detailing the state(s) who initiated the action and those who eventually joined onto the case. It is the disaggregation of this final point which makes this dataset the most fruitful for the current work. Never before has it been possible to determine with any certainty which states initiated what type of suit and whether it was a single, in-state action, an initiation of a multi-state suit or whether a state eventually participated in the multi-state suit once others had initiated. As suggested, both AG elections and gubernatorial elections in which a sitting AG ran may have a direct impact on antitrust enforcement. Therefore, Table 2.1 provides the difference-in-averages between nonelection years and both $\mathrm{AG}$ and gubernatorial election years in which a sitting AG ran for office.

Column 1 and 2 show the results for single, in-state actions. Here the average number of single state cases undertaken per year during off election years was 0.3538 , while the average during both AG and gubernatorial election years was 0.2956 and 0.3554 respectively. This suggests that single state actions actually fall fairly significantly during AG election years and rise only negligibly during gubernatorial elections in which a sitting AG ran. These initial results

\footnotetext{
${ }^{5}$ Although it would be highly beneficial to be able to extend this data further back in time, given the reporting methods from both state AGs and NAAG, it is a near impossibility. Although the NAAG database does carry and compile antitrust actions prior to 1990, it is not all inclusive. Therefore, in order to ensure that all actions are accounted for and following NAAG's recommendations, the dataset I have employed begins in 1990.
} 
would seem to indicate that AGs are far more reluctant to pursue antitrust actions that directly impact in-state firms and constituents during election years, and don't generally change enforcement behavior when running for a gubernatorial position. Intuitively this would make some sense as such antitrust enforcement would have a direct an potentially negative impact on both in-state firms, business interests and voters.

Table 2.1: Difference in Averages Results for AG and Gubernatorial Elections

\begin{tabular}{|c|c|c|c|c|c|c|}
\hline Type of Action & $\begin{array}{l}\text { Single State } \\
\text { Actions }\end{array}$ & $\begin{array}{c}\text { Single State } \\
\text { Actions }\end{array}$ & $\begin{array}{l}\text { Lead State } \\
\text { Actions }\end{array}$ & $\begin{array}{l}\text { Lead State } \\
\text { Actions }\end{array}$ & $\begin{array}{l}\text { Participatory } \\
\text { Actions }\end{array}$ & $\begin{array}{c}\text { Participatory } \\
\text { Actions }\end{array}$ \\
\hline \multicolumn{7}{|l|}{ Average Number of Actions } \\
\hline During Off-Election Years & 0.3538 & 0.3538 & 0.2791 & 0.2791 & 0.9784 & 0.9784 \\
\hline \multicolumn{7}{|l|}{$\begin{array}{r}\text { Average Number of Actions } \\
\text { During }\end{array}$} \\
\hline \multicolumn{7}{|l|}{ Attorneys General Election } \\
\hline \multicolumn{7}{|l|}{$\begin{array}{r}\text { Average Number of Actions } \\
\text { During }\end{array}$} \\
\hline Gubernatorial Election Years & 0.3554 & & 0.3064 & & 1.4436 & \\
\hline Difference In Averages & 0.0016 & -0.0582 & 0.0273 & 0.0223 & 0.4652 & 0.2744 \\
\hline
\end{tabular}

Note: Average number of Actions During Off-Election Years and Average Number of Actions During Attorneys General Election Years excludes case data for the seven states that appoint their AG, as there are by definition no AG elections in those states. Average number of Actions During Gubernatorial Election Years includes data for appointed AGs.

Next, columns 3 and 4 analyze the difference-in-averages for those states that initiated or led an antitrust case which eventually became a multi-state case. The average number of actions during non-election years was 0.2791, while during both gubernatorial and AG elections this average increased to 0.30645 and 0.3014 respectively, leaving a difference of 0.0273 and 0.0223 between gubernatorial and AG election years respectively. Thus, the evidence would suggest 
that AGs are more likely to initiate a multi-state antitrust action, during both an AG and gubernatorial election year.

Finally, columns 5 and 6 provide the difference-in-averages for participation in a multistate case both during election and non-election years. Here the results are much the same as those found for multi-state lead actions, except they are much larger and much more pronounced. Specifically, the average number of multi-state participatory cases over non-election years was 0.9785, increasing to 1.4436 and 1.2528 during both gubernatorial and AG election years respectively, for a difference of 0.4652 and 0.2744 cases. Thus, these initial results show that AGs will by-and-large avoid in-state actions while running for office, but will increase antitrust enforcement against out-of-state interests, especially once a multi-state case has been established. Overall, the difference-in-average results would seem to indicate that antitrust enforcement (for all types of actions, whether they be single, in-state actions, or multi-state actions) appear to follow electoral cycles for both the office of attorney general as well as for a gubernatorial post in which a sitting AG is running. The remainder of this section tests this more formally.

\subsubsection{The Model}

To further analyze these results I have constructed a balanced panel dataset from which to determine how exactly AG and gubernatorial elections, as well as certain legal and institutional constraints affect a state AG's decision to pursue antitrust violations. The model follows in the vein of Kubik and Moran (2003), who showed the impact that gubernatorial elections had on executions within a state. Their analysis found that after controlling for various other variables, states were approximately 25 percent more likely to execute an inmate during gubernatorial election years. Given the low propensity for executions to begin with, they incorporate a 
dichotomous dependent variable, which specifies whether or not a state had an execution in a given year.

My model also follows Provost (2006) who employs a logit model to test the implications and impact associated with interest group participation, state government ideology, and state citizen ideology on consumer protection enforcement by state AGs. He incorporated a logit model as overall state participation in consumer protection has been relatively low, thus also suggesting the employment of a dichotomous dependent variable to denote whether or not an AG undertook a consumer protection action in a given year.

As my difference-in-averages results indicate, state antitrust enforcement is similar in this manner in that annual participation by a state is relatively low for any given year. Therefore, I have also opted to incorporate a dichotomous dependent variable representing a " 1 " if an AG entered into an antitrust action in a given year and a " 0 " if he or she did not. Given this, I employ a logit model in order to measure the effect that the various institutional differences and election cycles may have on the decision to pursue single and multi-state antitrust cases. ${ }^{6}$ The model takes the following form:

$$
\begin{aligned}
\operatorname{Pr}\left(\text { Litigat }_{\mathrm{ijt}}\right) & =\Phi\left(\alpha+\beta_{1 t} \text { AGElection }_{i t}+\beta_{2 t} \text { Parens }_{i t}+\beta_{3 t} \text { TermLimit }_{t}\right. \\
& \left.+\beta_{4 t} \text { Party }_{i t}\right)+\mu_{i}+\varphi_{t}+\varepsilon_{i j t}
\end{aligned}
$$

And:

$$
\begin{aligned}
\operatorname{Pr}\left(\text { Litigat }_{\mathrm{ijt}}\right)= & \Phi\left(\alpha+\beta_{1 t} \text { GOVElection }_{i t}+\beta_{2 t} \text { Parensit }_{i t}+\beta_{3 t} \text { TermLimit }_{i t}\right. \\
& \left.+\beta_{4 t} \text { Party }_{i t}\right)+\mu_{i}+\varphi_{t}+\varepsilon_{i j t}
\end{aligned}
$$

\footnotetext{
${ }^{6}$ I opt to use a logit model for several reasons. First, the results from a probit analysis provide near identical results. Second, given the use of a logit model in other studies examining AG behavior, I have decided to remain consistent with that literature and adopt the model specified.
} 
With: $i=1, \ldots, 50 ; j=1, \ldots, 3 ; t=1, \ldots, 18$

Where, Litigate $i j t$ is a variable representing a " 1 " if an attorney general in state $i$ entered into at least one antitrust suit in year $t$, while $j$ represents which type of action it may have been: a single, in-state action, a multistate lead action, or a multistate participatory action. I have further broken this down and run regressions for both $\mathrm{AG}$ elections (represented by AGelection $_{\text {it }}$ in equation 1) and for gubernatorial elections involving an AG as a candidate (represented by GOVelectio $n_{i t}$ in equation 2). $\mu_{i}$ represents a set of state effects, $\varphi_{t}$ becomes the set of time effects, while $\varepsilon_{i j t}$ becomes the error term.

Overall, this model creates a set of six separate regressions: three of which run single, instate antitrust actions, lead actions and participatory actions as the dependent variable against equation (1) and three other regressions running the same dependent variables against equation (2). Parensit represents whether an AG in state $i$ has been granted parens patriae authority by a state legislature in year $t$ (coded as a " 1 " if he or she does and " 0 " otherwise). ${ }^{7}$ As noted, parens patriae effectively grants an AG to bring forth a class action lawsuit acting on behalf of the

\footnotetext{
${ }^{7}$ The variable representing parens patriae may have some potential endogeneity problems associated with it. Specifically, a state AG that increases the number and dollar amount of the awards brought into a state may simultaneously have a legislature more willing to grant parens patriae authority. Although this potential does exist, the historical record does not suggest the bias to be very likely as 15 states (30\% of all states) granted parens patriae in either 1977 or 1978 and another 8 states (16\% of all states) did so between 1990 and 1991 . These correspond with the two landmark Supreme Court cases: Illinois Brick v. Illinois and ARC v. California both decided in 1977 and 1990 respectively. Finally, another 7 states (14\% of all states) granted the authority in 1982, which coincides with a set of merger guidelines issued by the Department of Justice. As Flexner and Racanelli (1993) point out, "The states were dissatisfied with the minimal investigative attention given mergers by the DOJ as exemplified in its 1982 and 1984 Merger Guidelines. Further, the states perceived that the federal enforcers refused to challenge even those mergers which on their face satisfied the enforcement thresholds under their own guidelines." Given the evidence, it would appear that there were other exogenous forces that may have impacted the individual state Legislature's decision to grant parens patriae.
} 
citizens of his or her state. Simultaneously, state AGs are able to circumvent the procedural safeguards that must be met by private class action suits. Thus, I posit that a state AG with parens patriae will be more likely to undertake and pursue antitrust enforcement efforts compared to state AGs that do not.

TermLimitit represents if an AG in state $i$ is term limited in year $t$ (again coded as a " 1 " if he or she does face term limits and " 0 " otherwise). Party ${ }_{i t}$ represents whether an AG in state $i$ is a Republican (coded as a "1") or Democrat (coded as a "0") in year $t$. As a last I have also incorporated the four person, median household income, unemployment rates and population density as three control variables in the analysis. Two of these final three variables are meant to capture the potential party affiliation of the voter base in between the states, as higher median incomes and individuals living in more urban areas tend to vote more heavily Democratic. Finally, a higher unemployment rate may lead to reduced enforcement by an AG, as successful antitrust actions may lead to increased layoffs.

As an important caveat, seven states appoint their AGs, meaning there is no election perse. In order to account for this in my initial results, these states will be assumed to follow the gubernatorial election of their respective states, as various studies have shown that AGs, when appointed, are much more closely aligned with the interests of the executive (Lynch 2001; Marshall 2006). For robustness I further consider a different assumption regarding appointed AGs under a separate set of regressions by assuming they do not have an election at all (meaning that the AG election variable for those states is"0" between 1990-2008).

For the gubernatorial election variable I have compiled all of the state AGs who ran for governor while still holding their current office. This totals 53 AGs between 1990-2008 that fit this description. The information was collected from the Gubernatorial Campaign Expenditures 
Database, compiled by Thad Beyle and Jennifer M. Jensen. ${ }^{8}$ Their database provides the most detailed breakdown of gubernatorial elections from 1968 to the present. Most important for this current work is the fact that their dataset provides the occupation of each gubernatorial candidate at the time of his or her running. Therefore, it differentiates between whether an AG actually ran as an AG or as a former AG. Here I only consider those individuals who were currently AGs at the time of their decision to run.

I also include term limits as an explanatory variable in order to see if this may have any influence on a state AGs behavior given the potential last period problem (i.e. shirking). Specifically, research indicates that individual politicians and legislators will shirk more and participate less often within the political arena once they do not face the threat of reelection; where shirking is the situation under which a politician votes against the ideological preferences of his or her constituents (Bender and Lott 1996; Zupan 1990). Overall, this suggests that faced with an effective limit on holding office, individual political behavior may be affected. I have compiled this variable from The Book of the States for the given years. A term limit constraint may be highly influential on AG behavior, especially given that in 1990 there were only two states (Alabama and Pennsylvania) which had term limits on the office, while by 2008 this had grown to seventeen states.

Lastly, I have included a variable to account for the party affiliation of each state AG. Again, numerous works have shown the influence that party affiliation may play within the political and judicial arena. Smith and Tiller (2002) found that Federal judges appointed by Republicans appeared to rule against the Environmental Protection Agency more than Democratic appointees when faced with cases pertaining to environmental law. However,

\footnotetext{
${ }^{8}$ This database is freely available at http://www.unc.edu/ beyle/guber.html
} 
partisan effects on state AG behavior has been less clear. Provost (2006) finds no evidence to suggest that the party of a state AG affected his or her decision to undertake consumer protection cases. On the other hand, Spill, Licari and Ray (2001) found that Republican state AGs, especially those from states heavily dependent on tobacco were far less likely to join the multistate suit filed against the tobacco industry. Given this, it would seem that partisan effects may or may not have an influence on an AG's decision to undertake antitrust cases. Yet, given the general belief that Republican candidates and political figures are thought of as more "business friendly", there may be a decrease in enforcement by Republican AGs.

I have also included two other model specifications, which take the following form:

$$
\begin{aligned}
\operatorname{Pr}\left(\text { Litigate }_{\mathrm{ijt}}\right)= & \Phi\left(\alpha+\beta_{1 t} \text { GovElection }_{i t}+\beta_{2 t} \text { Party }_{i t}\right. \\
& \left.+\beta_{3 t} \text { GovElection }_{i x} x \text { Party }_{i t}\right)+\mu_{i}+\varphi_{t}+\varepsilon_{i j t}
\end{aligned}
$$

And:

$$
\begin{aligned}
\operatorname{Pr}\left(\text { Litigate }_{\mathrm{ijt}}\right)= & \Phi\left(\alpha+\beta_{1 t} \text { GovElection }_{i t}+\beta_{2 t} \text { Party }_{i t}\right. \\
& \left.+\beta_{3 t} \text { GovElection }_{i x} \times \text { Party }_{i t}\right)+\mu_{i}+\varphi_{t}+\varepsilon_{i j t}
\end{aligned}
$$

With: $i=1, \ldots, 50 ; j=1, \ldots, 3 ; t=1, \ldots, 18$

Where

$\beta_{3 t}$ AGElection $_{i t}$ Party ${ }_{i t}$ and $\beta_{3 i}$ GovElection $_{i t}$ Party $_{i_{t}}$ represent an interaction term between the party affiliation of an AG and whether or not that particular AG was up for election for his or her office or whether that individual ran for governor. These variables should show whether AGs of a particular party were more or less likely to enter into antitrust enforcement actions while also simultaneously running for their current office or while running for governor. The next section provides the results for these equations. 


\subsection{Results, Interpretation and Implications}

Overall the results provide interesting insights into how differences in legal and political arrangements affect not only the pursuit of antitrust actions but the type of action being pursued. Table 2.2 provides the random and fixed effects results for both AG and gubernatorial elections on single, in-state actions along with all other variables. ${ }^{9}$

Columns 1 through 4 provide the uncontrolled and controlled results for both the random and fixed effects estimates under AG elections while columns 5 through 8 provide the uncontrolled and controlled results for both the random and fixed effects estimates under gubernatorial elections involving a sitting AG respectively. Here I find that for both the random and fixed effects estimates an AG election does appear to reduce the likelihood of undertaking a single, in-state antitrust action. Specifically, the marginal effects estimates from column 1 and 2 both suggest that an AG election will reduce the likelihood of a single, in-state antitrust action by roughly $4 \%$, while columns 3 and 4 suggest an even larger decline of between $13 \%$ and $14.4 \%$ with and without controls respectively. Intuitively this would make sense, and would also conform to the difference-in-averages results I estimated, as in-state antitrust enforcement by an AG will have a direct and potentially negative impact on individual voters and business interests. Therefore, in-state enforcement, especially during an election, could create an extremely large political cost.

\footnotetext{
${ }^{9}$ The Hausman Results are mixed between a random and fixed effects model. This is generally due to the fact that there is little within-group variation for a number of observations, thus suggesting the use of a random effects model. However, when no observations are dropped from the fixed effects model (as in the results for multistate participatory actions) the Hausman results clearly indicate the use of a fixed effects model. Given this, and the fact that the results for both random and fixed effects estimates are similar, I have reported both.
} 
Table 2.2: Random and Fixed Effects Estimates for Single, In-State Antitrust Actions (Assuming Appointed AG Elections = 1 during each Respective State Gubernatorial Election).

\begin{tabular}{|c|c|c|c|c|c|c|c|c|}
\hline Independent Variable & \multicolumn{2}{|c|}{ Random Effects } & \multicolumn{2}{|c|}{ Fixed Effects } & \multicolumn{2}{|c|}{ Random Effects } & \multicolumn{2}{|c|}{ Fixed Effects } \\
\hline Constant & $\begin{array}{c}-2.197 * * * \\
(0.498)\end{array}$ & $\begin{array}{c}-3.603 * * * \\
(0.908)\end{array}$ & & & $\begin{array}{c}-2.326^{* * * *} \\
(0.495)\end{array}$ & $\begin{array}{c}-3.751 * * * \\
(0.900)\end{array}$ & & \\
\hline Attorney General Election & $\begin{array}{c}-0.040^{* *} \\
(0.243)\end{array}$ & $\begin{array}{c}-0.039 * * \\
(0.244)\end{array}$ & $\begin{array}{c}-0.144 * * \\
(0.240)\end{array}$ & $\begin{array}{l}-0.131^{*} \\
(0.242)\end{array}$ & & & & \\
\hline Gubernatorial Election & & & & & $\begin{array}{l}-0.026 \\
(0.458)\end{array}$ & $\begin{array}{l}-0.027 \\
(0.462)\end{array}$ & $\begin{array}{l}-0.108 \\
(0.453)\end{array}$ & $\begin{array}{l}-0.093 \\
(0.456)\end{array}$ \\
\hline Parens Patriae & $\begin{array}{l}0.017 \\
(0.417)\end{array}$ & $\begin{array}{l}0.019 \\
(0.420)\end{array}$ & $\begin{array}{l}-0.002 \\
(0.453)\end{array}$ & $\begin{array}{c}0.017 \\
(0.462)\end{array}$ & $\begin{array}{l}0.018 \\
(0.417)\end{array}$ & $\begin{array}{l}0.020 \\
(0.420)\end{array}$ & $\begin{array}{l}-0.001 \\
(0.455)\end{array}$ & $\begin{array}{c}0.016 \\
(0.465)\end{array}$ \\
\hline $\begin{array}{c}\text { Term Limits (= } 1 \text { if an AG } \\
\text { Is term limited) }\end{array}$ & $\begin{array}{l}-0.027 \\
(0.437)\end{array}$ & $\begin{array}{l}-0.020 \\
(0.439)\end{array}$ & $\begin{array}{l}-0.016 \\
(0.541)\end{array}$ & $\begin{array}{l}0.012 \\
(0.556)\end{array}$ & $\begin{array}{l}-0.026 \\
(0.434)\end{array}$ & $\begin{array}{l}-0.019 \\
(0.436)\end{array}$ & $\begin{array}{l}-0.013 \\
(0.537)\end{array}$ & $\begin{array}{c}0.015 \\
(0.552)\end{array}$ \\
\hline Party (= 1 if an AG is & $-0.033^{*}$ & -0.031 & -0.096 & -0.078 & $-0.034 *$ & $-0.032 *$ & -0.099 & -0.075 \\
\hline A Republican) & $(0.279)$ & $(0.281)$ & $(0.286)$ & $(0.289)$ & $(0.278)$ & $(0.280)$ & $(0.285)$ & $(0.288)$ \\
\hline Unemployment & & $\begin{array}{l}0.125^{*} \\
(0.091)\end{array}$ & & $\begin{array}{l}0.031 \\
(0.094)\end{array}$ & & $\begin{array}{l}0.013 * * \\
(0.090)\end{array}$ & & $\begin{array}{l}0.030 * \\
(0.094)\end{array}$ \\
\hline Median Household Income & & -0.010 & & -0.031 & & -0.010 & & -0.027 \\
\hline (In Thousands) & & $(0.131)$ & & $(0.137)$ & & $(0.130)$ & & $(0.136)$ \\
\hline Population Density & & 0.048 & & 0.141 & & 0.047 & & 0.128 \\
\hline (In Thousands) & & $(0.557)$ & & $(0.582)$ & & $(0.555)$ & & $(0.580)$ \\
\hline State Fixed Effects & & & Yes & Yes & & & Yes & Yes \\
\hline Year Fixed Effects & & & Yes & Yes & & & Yes & Yes \\
\hline Log-Likelihood & -352.072 & -349.182 & -236.800 & -234.655 & -355.05 & -352.034 & -239.672 & -237.430 \\
\hline Observations & 950 & 950 & 608 & 608 & 950 & 950 & 608 & 608 \\
\hline
\end{tabular}

(1) Clustered standard errors by state in parentheses. (2) Coefficients are the Average Marginal Effects. Statistical significance indicated as follows: ${ }^{* * *}=1 \% ;{ }^{* *}=5 \% ; *=10 \%$. 
The only other variable that at least shows some statistical significance is the party affiliation of an AG. Although the variable has a negative sign coefficient across the board (suggesting that Republican AGs are in fact less likely to pursue antitrust violations), the significance of the prediction is mixed. This would seem to coincide both with my initial prediction and with much of the literature that has examined partisan effects on AG and judicial behavior. For those results that are significant, the marginal effects suggest that Republican AGs are less likely to pursue antitrust violations by just over $3 \%$.

Although no other variables come out statistically significant, the resulting sign predictions would suggest that sitting AGs running for a gubernatorial position would reduce the likelihood of undertaking such actions, again suggesting that the potential impact that such enforcement may have on constituents could create an extremely high political cost for an AG looking to fill a gubernatorial post. Further, parens patriae authority generally appears to increase the likelihood of enforcement, suggesting that as the potential beneficiaries of a successful antitrust award increases so too might the prevalence of antitrust actions. Finally, the results for term limits are the most ambiguous, with both positive (columns 4 and 8) and negative (columns 1 through 3 and 5 through 7) coefficients. However, the marginal effects are negligible for each of the results, suggesting term limits play little if any role in an AG's decision to pursue in-state antitrust violations.

The next set of results records the impact of multi-state participatory actions by state AGs found in Table 2.3 for the random and fixed effects estimation. Again, columns 1 through 4 provide the uncontrolled and controlled results for both the random and fixed effects estimates under AG elections while columns 5 through 8 provide the uncontrolled and controlled results for both the random and fixed effects estimates under gubernatorial elections involving a sitting 


\section{Table 2.3: Random and Fixed Effects Estimates for Multistate Participatory Antitrust Actions (Assuming Appointed AG Elections = 1 During each Respective State Gubernatorial Election).}

\begin{tabular}{|c|c|c|c|c|c|c|c|c|}
\hline Independent Variable & \multicolumn{2}{|c|}{ Random Effects } & \multicolumn{2}{|c|}{ Fixed Effects } & \multicolumn{2}{|c|}{ Random Effects } & \multicolumn{2}{|c|}{ Fixed Effects } \\
\hline Constant & $\begin{array}{l}0.579 * * * \\
(0.199)\end{array}$ & $\begin{array}{c}1.684 * * * \\
(0.540)\end{array}$ & & & $\begin{array}{c}0.640 * * * \\
(0.192)\end{array}$ & $\begin{array}{l}1.869 * * * \\
(0.539)\end{array}$ & & \\
\hline Attorney General Election & $\begin{array}{c}0.092 * * * \\
(0.170)\end{array}$ & $\begin{array}{c}0.091 * * * \\
(0.172)\end{array}$ & $\begin{array}{c}0.113 * * * \\
(0.172)\end{array}$ & $\begin{array}{c}0.086 * * * \\
(0.173)\end{array}$ & & & & \\
\hline Gubernatorial Election & & & & & $\begin{array}{l}0.221 * * * \\
(0.481)\end{array}$ & $\begin{array}{l}0.227 * * * \\
(0.489)\end{array}$ & $\begin{array}{l}0.221 * * * \\
(0.487)\end{array}$ & $\begin{array}{l}0.341^{* * * *} \\
(0.495)\end{array}$ \\
\hline Parens Patriae & $\begin{array}{l}0.015 \\
(0.207)\end{array}$ & $\begin{array}{l}0.014 \\
(0.221)\end{array}$ & $\begin{array}{l}-0.001 \\
(0.269)\end{array}$ & $\begin{array}{l}-0.015 \\
(0.275)\end{array}$ & $\begin{array}{c}0.016 \\
(0.204)\end{array}$ & $\begin{array}{c}0.015 \\
(0.220)\end{array}$ & $\begin{array}{c}0.016 \\
(0.271)\end{array}$ & $\begin{array}{l}-0.010 \\
(0.278)\end{array}$ \\
\hline $\begin{array}{c}\text { Term Limits }(=1 \text { if an AG } \\
\text { Is Term limited })\end{array}$ & $\begin{array}{c}0.111^{* * *} \\
(0.207)\end{array}$ & $\begin{array}{c}0.115 * * * \\
(0.217)\end{array}$ & $\begin{array}{c}0.290 * * * \\
(0.327)\end{array}$ & $\begin{array}{r}0.195^{* * * *} \\
(0.338)\end{array}$ & $\begin{array}{l}0.105 * * * \\
(0.204)\end{array}$ & $\begin{array}{c}0.112 * * * \\
(0.215)\end{array}$ & $\begin{array}{c}0.105^{* * *} \\
(0.331)\end{array}$ & $\begin{array}{c}0.173 * * * \\
(0.344)\end{array}$ \\
\hline Party $(=1$ if an $A G$ is a & -0.047 & $-0.060^{*}$ & -0.072 & -0.049 & -0.047 & $-0.061 *$ & -0.047 & -0.041 \\
\hline Republican) & $(0.167)$ & $(0.174)$ & $(0.204)$ & $(0.206)$ & $(0.166)$ & $(0.174)$ & $(0.205)$ & $(0.207)$ \\
\hline Unemployment & & $\begin{array}{c}-0.044 * * * \\
(0.063)\end{array}$ & & $\begin{array}{c}-0.054 * * * \\
(0.074)\end{array}$ & & $\begin{array}{c}-0.047 * * * \\
(0.064)\end{array}$ & & $\begin{array}{c}-0.053 * * * \\
(0.075)\end{array}$ \\
\hline $\begin{array}{c}\text { Median Household Income } \\
\text { (In Thousands) }\end{array}$ & & $\begin{array}{l}-0.002 \\
(0.082)\end{array}$ & & $\begin{array}{l}0.002 \\
(0.090)\end{array}$ & & $\begin{array}{l}-0.005 \\
(0.082)\end{array}$ & & $\begin{array}{l}0.000 \\
(0.091)\end{array}$ \\
\hline $\begin{array}{l}\text { Population Density } \\
\text { (In Thousands) }\end{array}$ & & $\begin{array}{l}0.010 \\
(0.353)\end{array}$ & & $\begin{array}{l}-0.009 \\
(0.384)\end{array}$ & & $\begin{array}{l}0.024 \\
(0.354)\end{array}$ & & $\begin{array}{l}0.000 \\
(0.386)\end{array}$ \\
\hline State Fixed Effects & & & Yes & Yes & & & Yes & Yes \\
\hline Year Fixed Effects & & & Yes & Yes & & & Yes & Yes \\
\hline Log-Likelihood & -575.963 & -569.898 & -455.061 & -445.634 & -572.840 & -565.772 & -453.197 & -442.014 \\
\hline Observations & 950 & 950 & 950 & 950 & 950 & 950 & 950 & 950 \\
\hline
\end{tabular}

(1) Clustered standard errors by state in parentheses. (2) Coefficients are the Average Marginal Effects. Statistical significance indicated as follows: ${ }^{* * *}=1 \% ;{ }^{* *}=5 \% ; *=10 \%$. 
AG respectively. Here, the results show a significantly different and much more substantial outcome than under single, in-state actions. Specifically, I find that both AG elections and gubernatorial elections involving a sitting AG have a positive and statistically significant result. The marginal effects for the random effects estimates (columns 1 and 2) suggest that an AG election increases the likelihood of participating in multi-state antitrust actions by between $9.2 \%$ and $9.1 \%$ when including and excluding the control variables respectively, while columns 3 and 4 (the fixed effects results) suggest the likelihood increases to between $11.3 \%$ and $8.6 \%$ respectively.

For gubernatorial elections involving a sitting AG the results are even more striking: the marginal effects show an increase in the likelihood of participating in multi-state suits increases somewhere between $22.7 \%$ and $22.1 \%$ both with and without controls respectively, while columns 7 and 8 (the fixed effects estimates) suggest an increase in the likelihood of $22.1 \%$ and $34.1 \%$ respectively. The evidence further suggests that term limits may also have a significant impact. Here, all of the results seem to indicate that a term limited AG will significantly increase the likelihood of participating in a multi-state antitrust case. Specifically, the random effects marginal estimates (columns 1 and 2) indicate that a term limited AG will increase the likelihood of entering into a multistate antitrust case from between $11.1 \%$ to $11.5 \%$ both including and excluding the control variables if he or she is running for office, or if included with the gubernatorial election variable the likelihood increases from between $10.5 \%$ and $11.2 \%$ (for columns 5 and 6). These results are even more pronounced for the fixed effects estimates. One potential reason for this result may simply be that term limited AGs have less time to accomplish their pre-specified political goals while in office (if they do in fact include antitrust enforcement). Thus, it may be the case that term limited AGs will be more likely to enter into a 
multistate case more frequently in order to more rapidly meet these goals, or to convey to constituents a commitment to those goals.

For the parens patriae variable, although there is variation between the random and fixed effects estimates and none of these results are statistically significant, the random effects estimates suggest that an AG with parens patriae authority will be more likely to participate in multistate antitrust cases. Lastly, there again appears to be evidence that Republican AGs are less likely to participate in multistate cases, although only the random effects estimates with the control variables included (column 2) provided any statistically significant results.

The final specification is found within Table 2.4 which provides the results for lead actions undertaken by states that eventually develop into multi-state antitrust suits. As before, columns 1 through 4 provide the uncontrolled and controlled results for both the random and fixed effects estimates under AG elections while columns 5 through 8 provide the uncontrolled and controlled results for both the random and fixed effects estimates under gubernatorial elections involving a sitting AG respectively. Under these specifications, the results are clear: an AG with parens patriae authority is far more likely to initiate or lead a multi-state antitrust case. Specifically the marginal effects in columns 1 and 2 (the random effects estimates) suggest that an AG with parens patriae will increase the likelihood of leading a multi-state case from between $9.6 \%$ and $10.3 \%$ both with and without controls respectively, while columns 3 and 4 (the fixed effects estimates) suggest that this likelihood increases from between 16.8\% and $21.8 \%$ again with and without controls respectively. Columns 5 through 8 provide near identical results. 


\section{Table 2.4: Random and Fixed Effects Estimates for Multistate Lead Antitrust Actions (Assuming Appointed AG Elections = 1 During each Respective State Gubernatorial Election).}

\begin{tabular}{|c|c|c|c|c|c|c|c|c|}
\hline Independent Variable & \multicolumn{2}{|c|}{ Random Effects } & \multicolumn{2}{|c|}{ Fixed Effects } & \multicolumn{2}{|c|}{ Random Effects } & \multicolumn{2}{|c|}{ Fixed Effects } \\
\hline Constant & $\begin{array}{c}-2.782 * * * \\
(0.410)\end{array}$ & $\begin{array}{c}-3.647 * * * \\
(0.810)\end{array}$ & & & $\begin{array}{c}-2.800 * * * \\
(0.407)\end{array}$ & $\begin{array}{c}-3.675 * * * \\
(0.808)\end{array}$ & & \\
\hline Attorney General Election & $\begin{array}{l}-0.011 \\
(0.208)\end{array}$ & $\begin{array}{l}-0.011 \\
(0.213)\end{array}$ & $\begin{array}{l}-0.016 \\
(0.210)\end{array}$ & $\begin{array}{l}-0.013 \\
(0.215)\end{array}$ & & & & \\
\hline Gubernatorial Election & & & & & $\begin{array}{l}-0.015 \\
(0.394)\end{array}$ & $\begin{array}{l}-0.017 \\
(0.411)\end{array}$ & $\begin{array}{l}-0.030 \\
(0.395)\end{array}$ & $\begin{array}{l}-0.029 \\
(0.421)\end{array}$ \\
\hline Parens Patriae & $\begin{array}{c}0.103 * * * \\
(0.383)\end{array}$ & $\begin{array}{c}0.096 * * * \\
(0.401)\end{array}$ & $\begin{array}{c}0.218 * * \\
(0.438)\end{array}$ & $\begin{array}{c}0.168 * * \\
(0.441)\end{array}$ & $\begin{array}{c}0.103 * * * \\
(0.384)\end{array}$ & $\begin{array}{c}0.096 * * * \\
(0.401)\end{array}$ & $\begin{array}{c}0.216^{* *} \\
(0.439)\end{array}$ & $\begin{array}{l}0.164 * * \\
(0.442)\end{array}$ \\
\hline Term Limits $(=1$ if an AG & 0.063 & 0.053 & $0.154 * *$ & 0.060 & 0.063 & 0.053 & 0.152 & 0.058 \\
\hline Is Term Limited) & $(0.318)$ & $(0.343)$ & $(0.458)$ & $(0.486)$ & $(0.318)$ & $(0.343)$ & $(0.458)$ & $(0.485)$ \\
\hline Party $(=1$ if an AG is & 0.002 & -0.002 & 0.023 & 0.012 & 0.002 & -0.001 & 0.023 & 0.013 \\
\hline A Republican) & $(0.235)$ & $(0.247)$ & $(0.253)$ & $(0.265)$ & $(0.235)$ & $(0.247)$ & $(0.254)$ & $(0.266)$ \\
\hline Unemployment & & $\begin{array}{c}-0.028 * * * \\
(0.088)\end{array}$ & & $\begin{array}{c}-0.044 * * * \\
(0.093)\end{array}$ & & $\begin{array}{c}-0.028 * * * \\
(0.088)\end{array}$ & & $\begin{array}{c}-0.044 * * \\
(0.093)\end{array}$ \\
\hline Median Household Income & & 0.018 & & $0.025^{*}$ & & 0.018 & & $0.260 *$ \\
\hline (In Thousands) & & $(0.114)$ & & $(0.120)$ & & $(0.114)$ & & $(0.120)$ \\
\hline Population Density & & -0.055 & & -0.078 & & -0.056 & & -0.078 \\
\hline (In Thousands) & & $(0.483)$ & & $(0.509)$ & & $(0.484)$ & & $(0.510)$ \\
\hline State Fixed Effects & & & Yes & Yes & & & Yes & Yes \\
\hline Year Fixed Effects & & & Yes & Yes & & & Yes & Yes \\
\hline Log-Likelihood & -417.168 & -406.316 & -296.601 & -281.771 & -417.211 & -406.358 & -296.607 & 0281.749 \\
\hline Observations & 950 & 950 & 855 & 855 & 950 & 950 & 855 & 855 \\
\hline
\end{tabular}

(1) Clustered standard errors by state in parentheses. (2) Coefficients are the Average Marginal Effects. Statistical significance indicated as follows: $* * *=1 \% ; * *=5 \%$; $*=10 \%$. 
The results for both AG and gubernatorial elections all suggest that during an election an AG will be less likely to bring forth and lead a large-scale, multi-state antitrust case, however the results do not appear to be statistically significant. This is not the most unsurprising results, as initiating a case does indeed require a large, up-front cost that may or may not reap any immediate benefits to an AG. All of the results for the remaining variables in table 2.4 appear to have mixed sign coefficients, and are generally statistically insignificant, except for term limits under the fixed effects estimates, but only without any of the controls included.

Tables $2.5,2.6$, and 2.7 provide the results from the interaction analysis for equations (3) and (4) for in-state actions, participatory actions, and lead actions respectively. The results from Table V seem to suggest that a Republican running for either the AG office or gubernatorial office is more likely to undertake in-state antitrust actions as opposed to a Democratic candidate (however there is no statistical significance associated with the AG election). This result may suggest that if the median voter within a state responds more positively to antitrust efforts by an $\mathrm{AG}$, then the median voter effect may potentially dominate the special interest effect within a state. Thus, Republican candidates may be responding more strongly to that, as opposed to Democratic candidates.

Table 2.6 also suggests that Republican candidates, whether running for the office of AG or gubernatorial office are also more likely to participate in multistate cases (however here only weak statistical significance is found and only associated with an AG election). Finally, table 2.7 seems to indicate that while Democratic candidates running for the office of AG will increase their role in leading antitrust cases, Republican candidates will increase in that capacity if they are simultaneously running for governor. However, there does not appear to be any statistical significance associated with the finding. 


\section{Table 2.5: Random and Fixed Effects Interaction Estimates for Single, In-State Antitrust Actions (Assuming Appointed AG Elections = 1 During each Respective State Gubernatorial Election).}

\begin{tabular}{|c|c|c|c|c|c|c|c|c|}
\hline \multirow{2}{*}{$\begin{array}{c}\text { Independent Variable } \\
\text { Constant }\end{array}$} & \multicolumn{2}{|c|}{$\begin{array}{c}\text { Random Effects } \\
\text { (Without and with } \\
\text { Controls respectively) }\end{array}$} & \multicolumn{2}{|c|}{$\begin{array}{c}\text { Fixed Effects } \\
\text { (Without and with } \\
\text { Controls respectively) }\end{array}$} & \multicolumn{2}{|c|}{$\begin{array}{l}\text { Random Effects } \\
\text { (Without and with } \\
\text { Controls respectively) }\end{array}$} & \multicolumn{2}{|c|}{$\begin{array}{c}\text { Fixed Effects } \\
\text { (Without and with } \\
\text { Controls respectively) }\end{array}$} \\
\hline & $\begin{array}{c}-2.095 * * * \\
(0.377)\end{array}$ & $\begin{array}{c}-3.477 * * * \\
(0.848)\end{array}$ & & & $\begin{array}{c}-2.211 * * * \\
(0.371)\end{array}$ & $\begin{array}{c}-3.725 * * * \\
(0.844)\end{array}$ & & \\
\hline $\begin{array}{l}\text { Attorney General } \\
\text { Election }\end{array}$ & $\begin{array}{l}-0.047 * * \\
(0.294)\end{array}$ & $\begin{array}{l}-0.047 * * \\
(0.295)\end{array}$ & $\begin{array}{c}-0.171 * * * \\
(0.262)\end{array}$ & $\begin{array}{c}-0.165^{* * *} \\
(0.257)\end{array}$ & & & & \\
\hline Gubernatorial Election & & & & & $\begin{array}{l}-0.060 * \\
(0.709)\end{array}$ & $\begin{array}{c}-0.062 * * \\
(0.711)\end{array}$ & $\begin{array}{c}-0.269 * * \\
(0.547)\end{array}$ & $\begin{array}{c}-0.306 * * \\
(0.540)\end{array}$ \\
\hline Party ( $=1$ if an AG is & $-0.039^{*}$ & $-0.037 *$ & -0.121 & -0.103 & $-0.041 * *$ & $-0.039 * *$ & -0.127 & -0.100 \\
\hline A Republican) & $(0.307)$ & $(0.309)$ & $(0.449)$ & $(0.419)$ & $(0.285)$ & $(0.288)$ & $(0.495)$ & $(0.463)$ \\
\hline AG Election x Party & $\begin{array}{l}0.037 \\
(0.522)\end{array}$ & $\begin{array}{l}0.036 \\
0.526)\end{array}$ & $\begin{array}{l}0.100 \\
(0.364)\end{array}$ & $\begin{array}{l}0.079 \\
(0.385)\end{array}$ & & & & \\
\hline $\begin{array}{c}\text { Gubernatorial Election } \mathrm{x} \\
\text { Party }\end{array}$ & & & & & $\begin{array}{l}0.272 * \\
(0.974)\end{array}$ & $\begin{array}{l}0.320 * * \\
(0.986)\end{array}$ & $\begin{array}{l}0.377 * * \\
(0.747)\end{array}$ & $\begin{array}{l}0.220^{* *} \\
(0.463)\end{array}$ \\
\hline State Fixed Effects & & & Yes & Yes & & & Yes & Yes \\
\hline Year Fixed Effects & & & Yes & Yes & & & Yes & Yes \\
\hline Log-Likelihood & -352.26 & -349.28 & -236.51 & -234.39 & -353.63 & -350.07 & -237.96 & -235.37 \\
\hline Observations & 950 & 950 & 608 & 608 & 950 & 950 & 608 & 608 \\
\hline
\end{tabular}

(1) Clustered standard errors by state in parentheses. (2) Coefficients are the Average Marginal Effects. Statistical significance indicated as follows: $* * *=1 \% ; * *=5 \%$; $*=10 \%$.

As noted, the above results assumed that an appointed AG followed each of their respective state's gubernatorial election cycles. However, this assumption may be very strong. 
Table 2.6: Random and Fixed Effects Interaction Estimates for Multistate Participatory Antitrust Actions (Assuming Appointed AG Elections = 1 During each Respective State Gubernatorial Election).

\begin{tabular}{|c|c|c|c|c|c|c|c|c|}
\hline $\begin{array}{c}\text { Independent Variable } \\
\text { Constant }\end{array}$ & \multicolumn{2}{|c|}{$\begin{array}{c}\text { Random Effects } \\
\text { (Without and with } \\
\text { Controls respectively) }\end{array}$} & \multicolumn{2}{|c|}{$\begin{array}{c}\text { Fixed Effects } \\
\text { (Without and with } \\
\text { Controls respectively) }\end{array}$} & \multicolumn{2}{|c|}{$\begin{array}{c}\text { Random Effects } \\
\text { (Without and with } \\
\text { Controls respectively) }\end{array}$} & \multicolumn{2}{|c|}{$\begin{array}{c}\text { Fixed Effects } \\
\text { (Without and with } \\
\text { Controls respectively) }\end{array}$} \\
\hline Constant & $\begin{array}{c}0.844 * * * \\
(0.121)\end{array}$ & $\begin{array}{c}2.025 * * * \\
(0.522)\end{array}$ & & & $\begin{array}{c}0.852 * * * \\
(0.108)\end{array}$ & $\begin{array}{c}2.137 * * * \\
(0.518)\end{array}$ & & \\
\hline $\begin{array}{l}\text { Attorney General } \\
\text { Election }\end{array}$ & $\begin{array}{l}0.046 \\
(0.208)\end{array}$ & $\begin{array}{l}0.046 \\
(0.212)\end{array}$ & $\begin{array}{l}0.060 \\
(0.220)\end{array}$ & $\begin{array}{l}0.031 \\
(0.226)\end{array}$ & & & & \\
\hline Gubernatorial Election & & & & & $\begin{array}{l}0.177 * * \\
(0.549)\end{array}$ & $\begin{array}{l}0.192 * * \\
(0.559)\end{array}$ & $\begin{array}{l}0.241 * \\
(0.548)\end{array}$ & $\begin{array}{l}0.229 * * \\
(0.620)\end{array}$ \\
\hline Party ( $=1$ if an AG is & $-0.071 * * *$ & $-0.086 * *$ & $-0.102 *$ & $-0.053 * *$ & -0.046 & $-0.060 *$ & -0.071 & -0.032 \\
\hline A Republican) & $(0.183)$ & $(0.191)$ & $(0.226)$ & $(0.206)$ & $(0.163)$ & $(0.173)$ & $(0.216)$ & $(0.191)$ \\
\hline AG Election x Party & $\begin{array}{l}0.118 * \\
(0.359)\end{array}$ & $\begin{array}{l}0.118 * \\
(0.363)\end{array}$ & $\begin{array}{l}0.147 * \\
(0.346)\end{array}$ & $\begin{array}{l}0.093 * \\
(0.350)\end{array}$ & & & & \\
\hline $\begin{array}{c}\text { Gubernatorial Election } \mathrm{x} \\
\text { Party }\end{array}$ & & & & & $\begin{array}{l}0.197 \\
(1.172)\end{array}$ & $\begin{array}{c}0.182 \\
(1.184)\end{array}$ & $\begin{array}{l}0.266 \\
(1.17)\end{array}$ & $\begin{array}{c}0.162 \\
(1.253)\end{array}$ \\
\hline State Fixed Effects & & & & Yes & & & Yes & Yes \\
\hline Year Fixed Effects & & & & Yes & & & Yes & Yes \\
\hline Log-Likelihood & -578.771 & -572.57 & -462.367 & -449.08 & -576.28 & -569.35 & -461.31 & -446.19 \\
\hline Observations & 950 & 950 & 950 & 950 & 950 & 950 & 950 & 950 \\
\hline
\end{tabular}

(1) Clustered standard errors by state in parentheses. (2) Coefficients are the Average Marginal Effects. Statistical significance indicated as follows: ${ }^{* * *}=1 \% ;{ }^{* *}=5 \%$; ${ }^{*}=10 \%$.

Therefore, in order to analyze the robustness of my empirical analysis, I incorporate a different specification in order to account for this potential issue. In what follows I assume that 


\section{Table 2.7: Random and Fixed Effects Interaction Estimates for Multistate Lead Antitrust Actions (Assuming Appointed AG Elections = 1 During each Respective State Gubernatorial Election).}

\begin{tabular}{|c|c|c|c|c|c|c|c|c|}
\hline $\begin{array}{c}\text { Independent Variable } \\
\text { Constant }\end{array}$ & \multicolumn{2}{|c|}{$\begin{array}{l}\text { Random Effects } \\
\text { (Without and with } \\
\text { Controls respectively) }\end{array}$} & \multicolumn{2}{|c|}{$\begin{array}{c}\text { Fixed Effects } \\
\text { (Without and with } \\
\text { Controls respectively) }\end{array}$} & \multicolumn{2}{|c|}{$\begin{array}{c}\text { Random Effects } \\
\text { (Without and with } \\
\text { Controls respectively) }\end{array}$} & \multicolumn{2}{|c|}{$\begin{array}{c}\text { Fixed Effects } \\
\text { (Without and with } \\
\text { Controls respectively) }\end{array}$} \\
\hline Constant & $\begin{array}{c}-1.810 * * * \\
(0.232)\end{array}$ & $\begin{array}{c}-2.741 * * * \\
(0.740)\end{array}$ & & & $\begin{array}{c}-1.767 * * * \\
(0.222)\end{array}$ & $\begin{array}{c}-2.738 * * * \\
(0.736)\end{array}$ & & \\
\hline $\begin{array}{l}\text { Attorney General } \\
\text { Election }\end{array}$ & $\begin{array}{l}0.004 \\
(0.254)\end{array}$ & $\begin{array}{l}0.002 \\
(0.259)\end{array}$ & $\begin{array}{c}0.008 \\
(0.254)\end{array}$ & $\begin{array}{l}0.005 \\
(0.259)\end{array}$ & & & & \\
\hline Gubernatorial Election & & & & & $\begin{array}{l}-0.069 \\
(0.5980\end{array}$ & $\begin{array}{l}-0.064 \\
(0.627)\end{array}$ & $\begin{array}{l}-0.167 * \\
(0.385)\end{array}$ & $\begin{array}{l}-0.154 \\
(0.460)\end{array}$ \\
\hline Party $(=1$ if an $A G$ is & 0.029 & 0.023 & 0.086 & 0.065 & 0.007 & 0.005 & 0.047 & 0.035 \\
\hline A Republican) & $(0.258)$ & $(0.269)$ & $(0.274)$ & $(0.287)$ & $(0.238)$ & $(0.250)$ & $(0.377)$ & $(0.340)$ \\
\hline AG Election x Party & $\begin{array}{l}-0.389 \\
(0.441)\end{array}$ & $\begin{array}{l}-0.042 \\
(0.088)\end{array}$ & $\begin{array}{l}-0.104 \\
(0.444)\end{array}$ & $\begin{array}{l}-0.098 \\
(0.463)\end{array}$ & & & & \\
\hline $\begin{array}{c}\text { Gubernatorial Election } \mathrm{x} \\
\text { Party }\end{array}$ & & & & & $\begin{array}{c}0.173 \\
(0.812)\end{array}$ & $\begin{array}{l}0.136 \\
(0.844)\end{array}$ & $\begin{array}{l}0.199 \\
(0.632)\end{array}$ & $\begin{array}{l}0.119 \\
(0.668)\end{array}$ \\
\hline State Fixed Effects & & & Yes & Yes & & & Yes & Yes \\
\hline Year Fixed Effects & & & Yes & Yes & & & Yes & Yes \\
\hline Log-Likelihood & -422.47 & -410.93 & -301.54 & -285.03 & -422.08 & -410.77 & -301.34 & -285.05 \\
\hline Observations & 950 & 950 & 855 & 855 & 950 & 950 & 855 & 855 \\
\hline
\end{tabular}

(1) Clustered standard errors by state in parentheses. (2) Coefficients are the Average Marginal Effects. Statistical significance indicated as follows: ${ }^{* * *}=1 \% ;{ }^{* *}=5 \% ; *=10 \%$.

appointed AGs follow no particular electoral cycle. ${ }^{10}$ In other words, where I initially coded an AG election as a "1" for an appointed AG if his or her respective governor was up for election, I

\footnotetext{
${ }^{10}$ Here, I do not report the results for any of the interaction analysis from equations (3) and (4) as they were extremely similar to those found from the initial specification.
} 
now code all of those as a "0". These results can be found in tables 2.8, 2.9 and 2.10 for in-state, single state actions, multi-state participatory actions and multistate lead actions respectively. ${ }^{11}$ Here the results are virtually identical to all of those found in my original specifications. A comparison between these results and those I initially found suggest that outside of slightly different marginal effects results, the major sign coefficients and statistical significance remain the same between the two.

Overall, these results do seem to lend support to some rather interesting implications. Specifically, it would appear that influences on antitrust activity conducted by state AGs does depend upon the type of activity being pursued. As suggested, an election reduces the likelihood of an AG undertaking an in-state antitrust action, whereas both AG and gubernatorial elections involving an AG have a strong impact on the decision to participate in multi-state antitrust suits. Thus, it would seem that not only do in-state antitrust actions decline during AG elections but also that the strongest increases in antitrust activity are multi-state participatory actions. Participation in multi-state actions has become less costly over time, especially with the support system created by NAAG's Multi-state Antitrust Task Force. Further, it seems that participation in multi-state antitrust cases increasingly coincide with elections. Given this, state AGs have a means by which to potentially obtain awards from out-of-state firms and individuals and then directly pass those claims over to their constituents. As suggested, this has become more prevalent especially with the use of cy pres distribution. Thus, a situation is created whereby any potential downside attached to enforcement would generally only indirectly fall onto constituents, while those same constituents simultaneously are able to accrue the direct

\footnotetext{
${ }^{11}$ I only report the results for the AG election (columns 1 through 4 in tables 2.2 through 2.4) as there would be no change for the gubernatorial election regressions (columns 5 through 8 of tables 2.2 through 2.4).
} 
Table 2.8: Random and Fixed Effects Estimates for Single, In-State Antitrust Actions (Assuming Appointed AG Elections = 0 for all elections).

\begin{tabular}{|c|c|c|c|c|}
\hline Independent Variable & \multicolumn{2}{|c|}{ Random Effects } & \multicolumn{2}{|c|}{ Fixed Effects } \\
\hline Constant & $\begin{array}{c}-2.233^{* * * *} \\
(0.497)\end{array}$ & $\begin{array}{c}-3.640 * * * \\
(0.906)\end{array}$ & & \\
\hline \multirow[t]{2}{*}{ Attorney General Election } & $-0.036 * *$ & $-0.036 * *$ & $-0.135 * *$ & $-0.121 * *$ \\
\hline & $(0.258)$ & $(0.259)$ & $(0.255)$ & $(0.257)$ \\
\hline \multirow[t]{2}{*}{ Parens Patriae } & 0.017 & 0.019 & -0.002 & 0.017 \\
\hline & $(0.416)$ & $(0.419)$ & $(0.452)$ & $(0.462)$ \\
\hline Term Limit (= 1 if an AG is & -0.026 & -0.020 & -0.016 & 0.012 \\
\hline Term limited) & $(0.436)$ & $(0.438)$ & $(0.539)$ & $(0.554)$ \\
\hline Party $(=1$ if an $A G$ is a & $-0.033^{*}$ & $-0.031 *$ & -0.096 & -0.076 \\
\hline Republican) & $(0.279)$ & $(0.281)$ & $(0.285)$ & $(0.289)$ \\
\hline \multirow[t]{2}{*}{ Unemployment } & & $0.012^{*}$ & & $0.031 *$ \\
\hline & & $(0.091)$ & & $(0.094)$ \\
\hline Median Income & & -0.010 & & -0.031 \\
\hline (In Thousands) & & $(0.130)$ & & $(0.136)$ \\
\hline Population Density & & 0.049 & & 0.142 \\
\hline (In Thousands) & & $(0.556)$ & & $(0.580)$ \\
\hline State Fixed Effects & & & Yes & Yes \\
\hline Year Fixed Effects & & & Yes & Yes \\
\hline Log-likelihood & -352.947 & -349.983 & -237.620 & -235.403 \\
\hline Observations & 950 & 950 & 608 & 608 \\
\hline
\end{tabular}

(1) Clustered standard errors by state in parentheses. (2) Coefficients are the Average Marginal Effects. Statistical significance indicated as follows: ${ }^{* * *}=1 \% ;{ }^{* *}=5 \% ;{ }^{*}=10 \%$.

benefits. These enforcement efforts also provide a means for state AGs to make headlines for themselves, get their names in the media and earn exposure in front of constituents, which is a 
Table 2.9: Random and Fixed Effects Estimates for Multistate Participatory Antitrust Actions (Assuming Appointed AG Elections = 0 for all elections).

\begin{tabular}{|c|c|c|c|c|}
\hline Independent Variable & \multicolumn{2}{|c|}{ Random Effects } & \multicolumn{2}{|c|}{ Fixed Effects } \\
\hline Constant & $\begin{array}{c}0.602 * * * \\
(0.197)\end{array}$ & $\begin{array}{c}1.700 * * * \\
(0.539)\end{array}$ & & \\
\hline \multirow[t]{2}{*}{ AG Election } & $0.095 * * *$ & $0.094 * * *$ & $0.118 * * *$ & $0.090 * * *$ \\
\hline & $(0.183)$ & $(0.186)$ & $(0.189)$ & $(0.191)$ \\
\hline \multirow[t]{2}{*}{ Parens Patriae } & 0.014 & 0.012 & -0.002 & -0.015 \\
\hline & $(0.206)$ & $(0.220)$ & $(0.268)$ & $(0.274)$ \\
\hline Term Limit $(=1$ if an AG is & 0.106 & 0.112 & 0.292 & 0.194 \\
\hline Term limited) & $(0.206)$ & $(0.216)$ & $(0.327)$ & $(0.338)$ \\
\hline Party $(=1$ if an $A G$ is a & -0.046 & $-0.059 *$ & 0.072 & -0.049 \\
\hline Republican) & $(0.167)$ & $(0.174)$ & $(0.204)$ & $(0.206)$ \\
\hline \multirow[t]{2}{*}{ Unemployment } & & $-0.440 * * *$ & & $-0.054 * * *$ \\
\hline & & $(0.063)$ & & $(0.074)$ \\
\hline Median Income & & -0.002 & & 0.002 \\
\hline (In Thousands) & & $(0.082)$ & & $(0.090)$ \\
\hline Population Density & & 0.009 & & -0.011 \\
\hline (In Thousands) & & $(0.352)$ & & $(0.384)$ \\
\hline State Fixed Effects & & & Yes & Yes \\
\hline Year Fixed Effects & & & Yes & Yes \\
\hline Log-likelihood & -576.178 & -570.124 & -455.491 & -445.973 \\
\hline Observations & 950 & 950 & 950 & 950 \\
\hline
\end{tabular}

(1) Clustered standard errors by state in parentheses. (2) Coefficients are the Average Marginal Effects. Statistical significance indicated as follows: ${ }^{* * *}=1 \% ;{ }^{* *}=5 \% ;{ }^{*}=10 \%$.

tactic often employed by AGs (Lemos forthcoming).

Further, an AG with parens patriae authority appears to drive the decision to initiate 
Table 2.10: Random and Fixed Effects Estimates for Multistate Lead Antitrust Actions (Assuming Appointed AG Elections = 0 for all elections).

\begin{tabular}{|c|c|c|c|c|}
\hline Independent Variable & \multicolumn{2}{|c|}{ Random Effects } & \multicolumn{2}{|c|}{ Fixed Effects } \\
\hline Constant & $\begin{array}{c}-2.805 * * * \\
(0.409)\end{array}$ & $\begin{array}{c}-3.675^{* * *} \\
(0.809)\end{array}$ & & \\
\hline \multirow[t]{2}{*}{ Attorney General Election } & -0.001 & -0.002 & -0.006 & -0.005 \\
\hline & $(0.217)$ & $(0.222)$ & $(0.219)$ & $(0.225)$ \\
\hline \multirow[t]{2}{*}{ Parens Patriae } & $0.103 * * *$ & $0.097 * * *$ & $0.217 * * *$ & $0.165^{* *}$ \\
\hline & $(0.383)$ & $(0.401)$ & $(0.438)$ & $(0.441)$ \\
\hline Term Limit $(=1$ if an AG is & 0.063 & 0.054 & $0.153 * *$ & 0.059 \\
\hline Term limited) & $(0.318)$ & $(0.343)$ & $(0.458)$ & $(0.486)$ \\
\hline Party $(=1$ if an $A G$ is a & 0.001 & -0.002 & 0.022 & 0.011 \\
\hline Republican) & $(0.235)$ & $(0.247)$ & $(0.253)$ & $(0.265)$ \\
\hline \multirow[t]{2}{*}{ Unemployment } & & $-0.028 * * *$ & & $-0.044 * * *$ \\
\hline & & $(0.088)$ & & $(0.093)$ \\
\hline Median Income & & 0.018 & & $0.025^{*}$ \\
\hline (In Thousands) & & $(0.000)$ & & $(0.001)$ \\
\hline Population Density & & -0.055 & & -0.077 \\
\hline (In Thousands) & & $(0.000)$ & & $(0.000)$ \\
\hline State Fixed Effects & & & Yes & Yes \\
\hline Year Fixed Effects & & & Yes & Yes \\
\hline Log-likelihood & -417.265 & -406.437 & -296.682 & -281.875 \\
\hline Observations & 950 & 950 & 855 & 855 \\
\hline
\end{tabular}

(1) Clustered standard errors by state in parentheses. (2) Average Marginal Effects in Brackets.

Statistical significance indicated as follows: ${ }^{* * *}=1 \% ;{ }^{* *}=5 \% ; *=10 \%$.

multi-state actions. This seems unsurprising as with parens patriae authority an AG has the statutory power to bring what is essentially a class action lawsuit on behalf of his or her 
constituents and therefore increase the expected payout from leading an antitrust suit. Any antitrust action requires an AGs office to generally incur a substantial cost. The larger the case, the larger will be that cost. However, by increasing the potential payout as parens patriae authority does through its class action provision, the potential benefit is greatly enhanced for those AGs who initiate large scale cases against larger and more powerful interests. Although the cost of the action may increase, with parens patriae authority so too does the potential benefit from a successful antitrust suit. Combined, all of this evidence would seem to suggest that state AGs do in fact employ antitrust enforcement as part of their policy agenda in different ways depending not only on their political ambitions, but also based on the legal constraints faced. Most significant, appears to be the impact that elections and electoral cycles have on an AGs decision to pursue in-state and multi-state antitrust actions over time.

\subsection{Conclusion}

The office of state attorney general has developed into an extremely important position. Given the general nature of the office, and its evolving and constantly oscillating power, it seems a natural place to test the implications of various legal structures and political institutions. Although in almost all states the office was held in little esteem or regard prior to the early 1970's, after that time its role increased exponentially, resulting in its becoming a springboard into higher office at both the state and federal level (Provost 2010).

This current work has attempted to analyze how these changes have specifically impacted state level antitrust enforcement. Overall, I found strong evidence to suggest that relatively more politically ambitious state AGs were more likely to increase the enforcement of and participation in multistate antitrust cases. Further, specific legal constraints including term limits and parens 
patriae authority also influence the type of antitrust actions a state AG pursues. These results appear unique and add greatly to the literature and existing debate about the proper scope of state level antitrust enforcement.

However, there is still much room to continue this line of work. Specifically, there has been little attention paid to the role that the National Association of Attorneys General has played in its capacity to lobby state and federal legislatures as well as its coordination of state AG activity in general and antitrust enforcement in particular. Such an understanding may better help us to comprehend the behavior of state AGs at both the national and state level. Further, there has been almost no consideration made in regard to state level changes that occurred during the 1960's, which greatly changed the scope and role of the office of state AG and helped to foster changes at the federal level. With both of these considerations more fully understood it may then be possible to know and decipher the exact nature of the office as it stands today. 


\section{Chapter 3}

\section{Entrepreneurship, Innovation, and Legal Federalism: A Schumpeterian Approach}

\subsection{Introduction}

Federalism has been at the heart of the American political tradition since the county's founding. Within the American tradition federalism has come to mean a system of governance whereby specific and distinct powers and responsibilities are delegated to different levels of government. Thus, the system is one in which both the states and federal government have separate and autonomous roles from one another.

A large literature has evolved to examine how government spending and taxes are determined within a federal system (the literature on "fiscal federalism"), much of it founded in the seminal work of Charles Tiebout (1956). This analysis centered on the overall consequences that would result from competition between various governmental units and jurisdictions in tax and expenditure policies. Specifically, if citizens have perfect information, are perfectly mobile, and if there are a large number of jurisdictions with no spillover effects occurring between jurisdictions due to the provision of public goods, then each citizen will self select into a jurisdiction based on his or her preference for public goods and willingness to pay for those goods through taxation. This competition over mobile resources, much as market competition does, can lead to greater efficiency within the public sector's fiscal policies.

When the assumption of no spillover or externality effects is relaxed, however, there may be an incentive for localities to "overproduce" those public goods that create a negative externality and "under-produce" those goods which create a positive externality, potentially leading to a "race-to-the-bottom" in policy (Konisky 2007; Oates 2001; Revesz 1996, 1997). 
This has led to a general consensus in the literature that the powers of government should be decentralized to the lowest level that fully internalizes all costs and benefits associated with the policy decision (Inman and Rubinfeld 1997).

A more recent body of literature following in the vein of Tiebout (1956) has also developed within legal scholarship. This "legal federalism" attempts to apply the lessons of economic theory to provide insight into the devolution of both legal and regulatory rule making (Bratton and McCahery 1997). Most notably this work has focused on the impact of environmental policy and regulation (Stewart 1977a, 1977b; Konisky and Woods 2009; Konisky 2010), corporate law and corporate chartering (Bebchuk 2002; Bebchuk and Cohen 2003; Bebchuk, Cohen and Ferrell 2002; Cary 1974; Romano 1985), banking and financial regulation (Scott 1977; Butler and Macey1988; Garten 1996) and antitrust enforcement (Easterbrook 1983; Lynch 2001; Posner 2004; Greve 2005). Ultimately, the application of economic analysis within the legal framework of federalism has led to an important assertion: that competition is instrumental in shaping numerous outcomes at state and local levels of government due to the fact that regulatory policy has a significant impact upon locational choice of firms and individuals. Overall, this literature - like its counterpart in fiscal federalism - has resulted in a long-standing debate as to whether decentralization and devolution of regulatory responsibility leads to a "race-to-the-top" and is thus welfare enhancing or a "race-to-the-bottom" and would therefore decrease welfare.

This chapter expands on the concept of horizontal legal federalism, or competition between states, by focusing on its impact on innovation and entrepreneurship. In addition, we consider this question from an entirely new direction by considering how entrepreneurial innovation itself helps to drive the process of dynamic legal evolution (the application of law 
into new areas), under a system of legal federalism. Specifically, our work is an attempt to lay a slightly new "Schumpeterian" framework within which to consider legal federalism.

We first argue that businesses and entrepreneurs must constantly manage a portfolio of legal risks just as they must manage financial and other market risks. For any given business, some of these legal risks depend on the principal place of business or incorporation, while others do not. Given this, the impact of legal variation on the locational choice of entrepreneurs will vary greatly depending on the nature of the specific business and the product or service sold. Jurisdictions that increase the expected legal risk businesses face will ultimately hamper some types of business activity more than others. For example, an entrepreneurial LASIK eye surgeon's legal risk for medical malpractice will mainly depend on home state laws while a large national manufacturer, even with only one manufacturing facility, will face product liability risk across all fifty states.

Next, we argue that the Schumpeterian notion of entrepreneurial "creative destruction", which creates new and revolutionary products within the marketplace while simultaneously rendering others obsolete (Schumpeter 1934[2007], 1942), sets in motion a process of creative destruction within the existing body of law, as law must be applied or created in response to new innovations and technological advances. This also adds to Knight (1921[2005]) who specifically argues crucial distinctions between risk and uncertainty. In other words, all risk is effectively an insurable event and thus has a predictably known future, while uncertainty is uninsurable as there is no probability that can be attached to the given event actually occurring moving into the future. Thus, within Knight's framework, at least at the margin, entrepreneurs will locate in those jurisdictions which provide the most predictable legal risk, and least amount of legal uncertainty. 
Innovations like the internet create a need for applications of law into the digital arena, while innovations like the automobile require new applications of precedent from existing laws. Similarly, medical innovations in cloning and stem cells create a need for entirely new areas of law to be developed. Therefore, what matters most to an entrepreneur is the predictability with which a jurisdiction's laws will be applied into these new areas. For entrepreneurs to be willing to make large up-front investments in research, development, and manufacturing facilities, they need to be fairly certain how the existing laws in the state in which they locate will be applied and interpreted into the new areas related to the innovative good or service produced by the entrepreneur. From this, we suggest that a system of decentralized federalism with horizontal competition automatically sets up the evolutionary process necessary for specific locations to spontaneously create new bodies of law and legal precedent most conducive to these new entrepreneurial innovations, allowing for certain jurisdictions to specialize in and capitalize on legal comparative advantages.

Lastly, we consider how the variation in law present under horizontal legal federalism is a key determinant of the overall productivity of an area's existing entrepreneurial resources. Following the logic of Baumol (1990), the differences in economic incentives created by differences in legal structures impacts whether an economy's entrepreneurs spend their time and talents engaging in productive (versus unproductive) activities. Areas with laws that make it easy for entrepreneurial individuals to profit in the private marketplace will create incentives for innovation and growth, while those areas with laws that make it profitable to engage in attempts to transfer wealth through the legal and political systems will incentivize these same individuals to spend their time and talents engaging in lawsuit abuse and lobbying activities, destroying wealth in the process. 
Most important in this context is the role that horizontal competition plays in minimizing unproductive entrepreneurship. Just as we argue for productive entrepreneurship, unproductive entrepreneurs also prefer those locations offering a predictable comparative advantage within the specific legal context most conducive to them. However, following Weignast (1995) we suggest that horizontal competition over legal regimes creates an automatic check against the expansion of unproductive entrepreneurship and is thus superior to greater centralization.

Therefore, our work suggests a new means by which to approach the decision to either decentralize or centralize certain aspects of the rule making and regulatory authority based around this portfolio of legal risk as well as our notion of legal creative destruction. Just as experimentation within the marketplace and the entrepreneurship this fosters is crucial to economic progress, so too might a system of greater decentralization within the legal sphere help to foster this by capitalizing on local and dispersed knowledge (Hayek 1945), and thus better avoid the potential for suboptimal path dependence, a risk associated with greater centralization (North 1990).

We support these conclusions empirically with data from the Institute for Legal Reform's State Liability Systems Ranking for each of the fifty states as well as state-level data on the locational choices of Fortune 500 companies, patent activity, and establishment birth rates. Our findings lend evidence to the conjecture that firms will locate in jurisdictions that not only minimize their bundle of legal risk, but also where entrepreneurial creative destruction is most welcomed by predictable application of law into new areas.

\subsection{Entrepreneurship, Risk, Return and the Law}


There exists a very strong and definite relationship between entrepreneurial activity and the law. In order to better understand this it is important to dissect two important aspects associated with any entrepreneurial or business decision: risk and return. All economic activity involves some varying degree of risk attached to it. Therefore, those activities must simultaneously provide a return on investment suitable enough to cover not only the opportunity cost associated with undertaking such activity, but also the associated risk. Naturally, entrepreneurs prefer a larger return and smaller risk.

Within this framework there are ultimately two potential forms of risk that can develop: market risk and legal risk. Market risk is simply the financial risk associated with the failure of an entrepreneurial venture in the marketplace. This market risk arises due to the imperfect knowledge and information about market participants by entrepreneurs trying to capitalize on dispersed and unique knowledge in order to seek out arbitrage opportunities and meet consumer demand (Hayek 1945; Kirzner 1978, 1997). These opportunities are known to be successes or failures only once discovered through the resulting signal of profit and loss attached to an activity. Entrepreneurs unable to properly forecast consumer preferences therefore incur the loss associated with those incorrect decisions. It is this loss that can be thought of as the risk associated with the marketplace. The unique feature of market risk that distinguishes it from legal risk is that an entrepreneur is able to control his or her maximum exposure to market risk through the ability to control the initial financial investment.

The second type of risk that entrepreneurs may face is legal risk. There are two important characteristics attached to legal risk. First unlike market risk, entrepreneurs cannot limit or control their maximum exposure. An entrepreneur running a restaurant chain who opens a location in a new state may draw a lawsuit in this new jurisdiction. However, a case heard in this 
new venue may result in a legal liability that far exceeds the investment made in that establishment, forcing the firm to drain resources away from operations in other locations. This type of legal risk can best be illustrated through punitive damage awards, or other civil and criminal penalties.

As the legal system currently stands choice of venue is generally tilted in favor of the plaintiff, which may lead to suboptimal outcomes as the plaintiff does not necessarily fully internalize all of the externalities associated with a given legal remedy. For example, suppose a relatively more stringent antitrust statute exists within West Virginia, and a suit is brought forth within a West Virginia court under West Virginia law against an out-of-state firm. With a successful suit under a stricter law, the benefits now accrue to individuals within West Virginia, while the cost spills over onto individuals and firms in other states. Further, this increases the risk exposure for both potential and actual entrepreneurs operating within other states without adversely affecting litigious behavior in West Virginia.

Secondly, predictability of the application of law will have a large influence on decision making, and as such is a major component to entrepreneurial activity. Ultimately, predictability within the law creates an automatic incentive for individuals to commit to and undertake long term plans and business decisions, while also clearly defining a known and delimited sphere within which each entrepreneur may operate under without fear of adverse consequence (Hayek 1960). Within this context, consistency in the law and its enforcement are welfare enhancing in that they reduce the inherent uncertainty attached to the unknown future of the marketplace. These multiple layers of legal risk that arise constantly require entrepreneurial and business decision makers to manage a bundle of legal risks within their given portfolio. While firms and entrepreneurs are able to control the home state risk they face given the freedom to choose where 
to locate or incorporate, the risk associated with economic activity across multiple states is far less controllable or predictable.

Given the current context as laid forth, what becomes most relevant for business and entrepreneurial decision making is the ability to manage this portfolio of legal risk. Thus, when making decisions firms and entrepreneurs must be able to assess and weigh the probability of the type of risk they may be faced with. This implies that it will be the overall probability of the type of risk which will affect the type of business and entrepreneurial activities that will take place within a given state or location. This we will address in Section 4.

\subsection{Entrepreneurial Innovation and the Evolution of the Law}

It is essential to understand entrepreneurship as a process of creative destruction (Schumpeter 1942). In other words, entrepreneurship leads to new innovative goods and services that make previous inventions and discoveries obsolete. This creates a constant disequilibrating process within the marketplace as these new discoveries emerge. The significance of this process can be seen when viewing its impact on legal and legislative institutions. By definition this process creates a need or demand for making new areas of law, or applying existing law to new areas not previously discovered or considered before. To our knowledge this aspect of entrepreneurship underpinning legal discovery within a system of federalism has never been investigated. The net result from this process of both legal and market creative destruction will be one in which Schumpeterian entrepreneurship will migrate to those locations which create a legal environment that adapts the most predictably to these new innovations.

This occurs due to the very nature of creative destruction. With the advent of a new innovation or technological breakthrough a simultaneous need for legislative or judicial 
entrepreneurship emerges. In other words, new bodies of law or precedent will eventually emerge as new and unforeseen legal issues surrounding entrepreneurial discoveries arise. However, the trajectories along which these legal changes may take, like technological changes, are inherently unpredictable.

In this context, greater horizontal competition between jurisdictions sets in motion a process that allows jurisdictions to discover how to best reduce the variance associated with legal unpredictability and simultaneously draw in those entrepreneurs most in need of minimizing their particular legal risk exposure associated with their own activities, and who simultaneously require predictability within the body of law most significantly related to their activities. Therefore, a decentralized legal system offers the potential for multiple new applications or areas of law to emerge and compete, while a centralized legal system would alternatively create a set of uniform legal standards in order to deal with issues arising from new Schumpeterian discoveries. This greater centralization increases the probability that the chosen legal regime will be inferior, yet may also be extremely costly to change, with the overall result being path dependence along a suboptimal trajectory (North 1990). When legal discovery is left to fifty different governing bodies, this competitive process will result in an evolutionary process of legal trial and error (Hayek 1960). Over time, the dominant legal regime would become the one most sought after by entrepreneurs, with the ensuing benefits accruing to the jurisdiction or jurisdictions adopting that regime.

Within this framework each state initially competes over new applications or bodies of law. Through legal evolution some states are able to develop comparative advantages over a given subset of the law, occurring as this body of law influences firm and entrepreneurial locational choice. Over time states that have legislatively created the most conducive law to a 
given entrepreneurial activity will enjoy an inflow of that activity. This leads to increased precedent being set within the courts of that state and an increased knowledge at the judicial level over only a small subsection of the law. Delaware provides a ready example of this behavior in regard to corporate law.

The first modern body of corporate law was passed in 1896 in the state of New Jersey (Cary 1974). For a time the state saw an inflow of corporate chartering. However, shortly thereafter Delaware passed its own legislation governing corporate behavior. This led to a period in which the two states competed with one another, with Delaware clearly emerging ahead. As such, Delaware has now enjoyed the creation and discovery of legal precedents for nearly a century within a highly technical and specialized area of the law. Further, many of the legal changes that do occur across the states regarding corporate law emerge from Delaware (Romano 1985). Thus, Delaware has been able to capitalize on its comparative advantage within corporate law and has increased the predictability associated with the evolutionary and competitive process of the law. The result has been an inflow of entrepreneurial activity, notably corporate governance. Not only has the state legislature adhered to a binding set of rules governing corporate law, so too has the judiciary through a long history of consistent legal precedent.

Overall, these predictions suggest an alternative or at least supplementary view in regard to the clustering of entrepreneurial industries. Often the clustering of innovative industries is attributed to specific resources in a given area. However, it would seem that industrial clusters may also (or primarily) develop in response to legal comparative advantages and legal predictability. 


\subsection{Data}

Differences in state legal systems with respect to the treatment of businesses and entrepreneurs are admittedly difficult to measure. Probably the most comprehensive and consistent index available is from The Institute for Legal Reform's biannual report State Liability Systems $\underline{\text { Ranking. Overall, the study includes a nationally representative sample of } 1482 \text { senior legal }}$ representatives of business firms with annual revenues of at least $\$ 100$ million. The survey measures perceptions over a set of ten different components of the legal liability system of each state. Each respondent was required to give a letter grade to each of the subcategories and then to the overall legal environment of each state. From this the Harris Poll created both an overall score from a 100 point scale ( 0 being the worst and 100 the best) as well as a 5 point grade (again 0 being the worst and 5 being the best). Our goal is to use this ranking of legal quality as a proxy for legal predictability.

As an initial inspection of how this legal index correlates with a state's overall economic performance, Figure 3.1 plots a state's income growth against the legal index score. On the xaxis is the average legal system quality score from 2002-2007, compared against each state's average annual economic growth rate from 1995-2005 on the y-axis. The figure shows a positive correlation between a state's legal quality and its economic growth rate. Specifically, the higher the score a state receives on the legal index the higher has been a state's average rate of economic growth. Figure 3.2 shows how the average legal system quality score correlates with state per capita income for 2005. Again, there is a definite positive correlation between a state's overall legal index score and per capita income. Thus, states with higher legal index scores are also wealthier. This may be a direct result associated with the increased predictability in these legal regimes. 
Figure 3.1: State Legal System Scores and State Income Growth

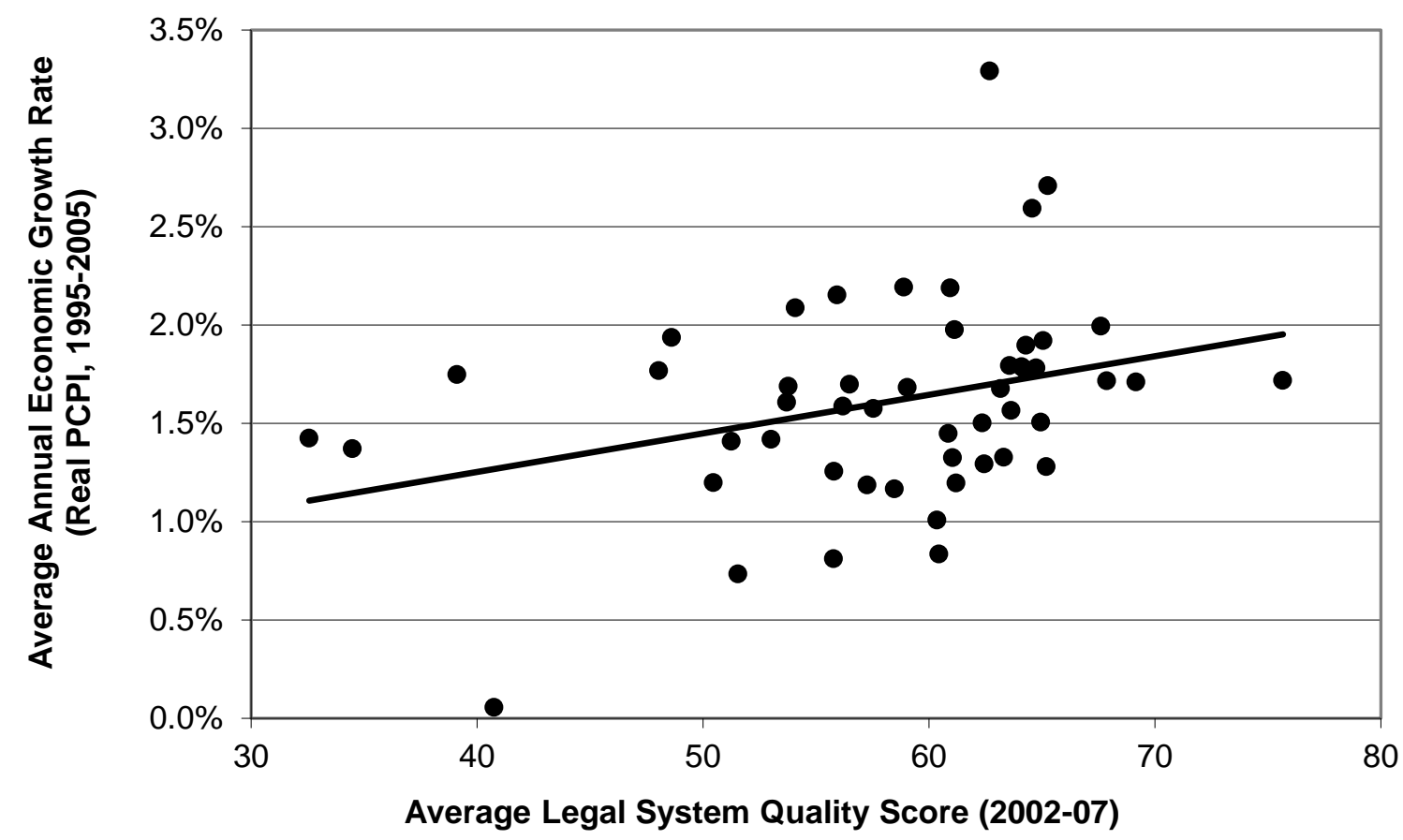

Figure 3.2: State Legal System Ranking and State Income Level

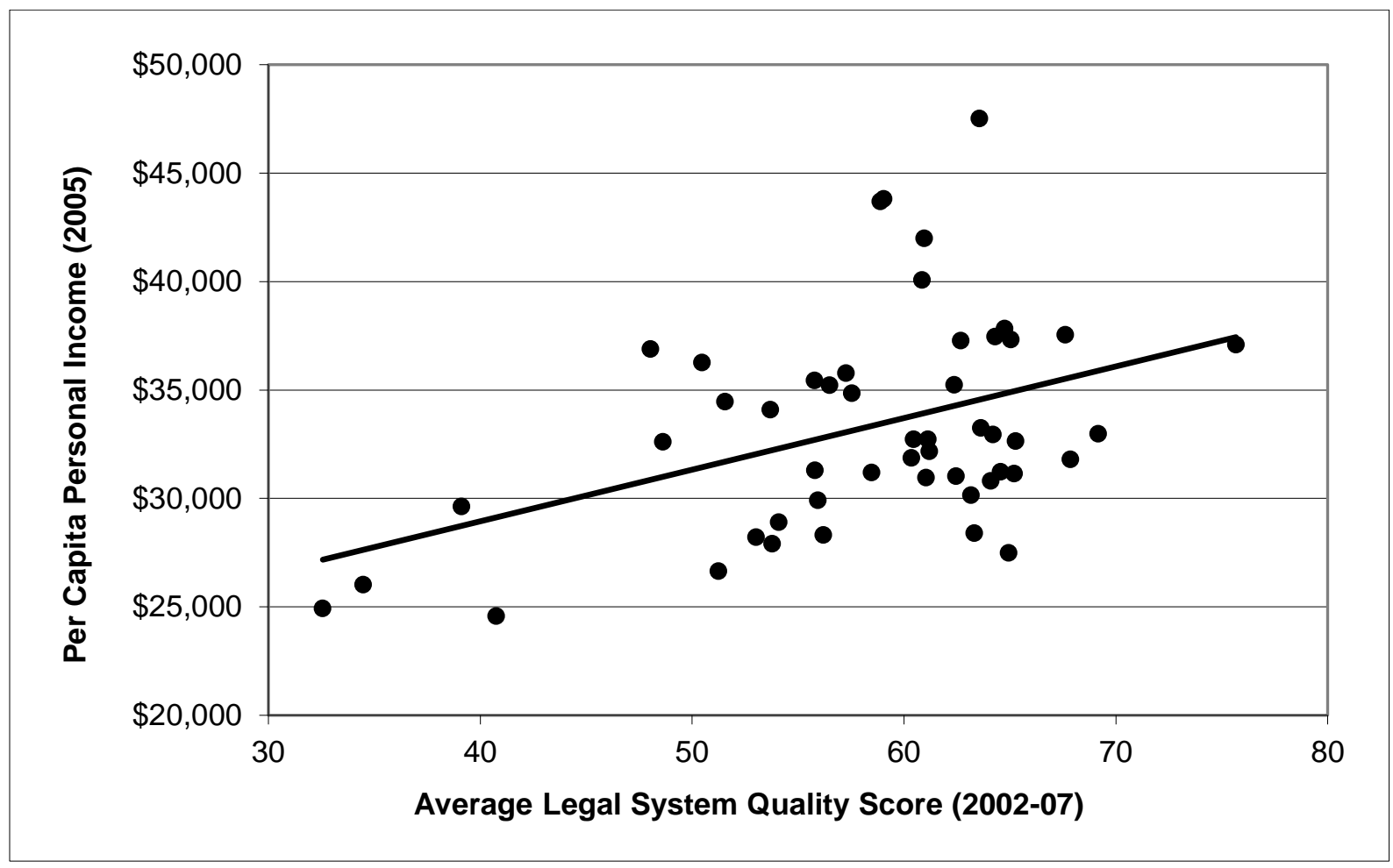


In order to further draw out these implications and to better understand our framework within the context of risk and uncertainty, figures 3.3 through 3.10 show the correlation between total monetary tort losses across the states and each of the measures provided by the State

\section{Liability Tort Index. $^{12}$}

Here the implications seem clear, higher scores on the Liability Index are associated with lower tort claims and awards. The only exception appears to be the rules regarding scientific and technical evidence, which is effectively flat. Overall, this would seem to suggest that more predictable judicial outcomes (and thus greater certainty pertaining to legal risk), is associated with higher overall legal quality.

Figure 3.3: Correlation of Total Monetary Tort Losses and Overall Liability Index Score

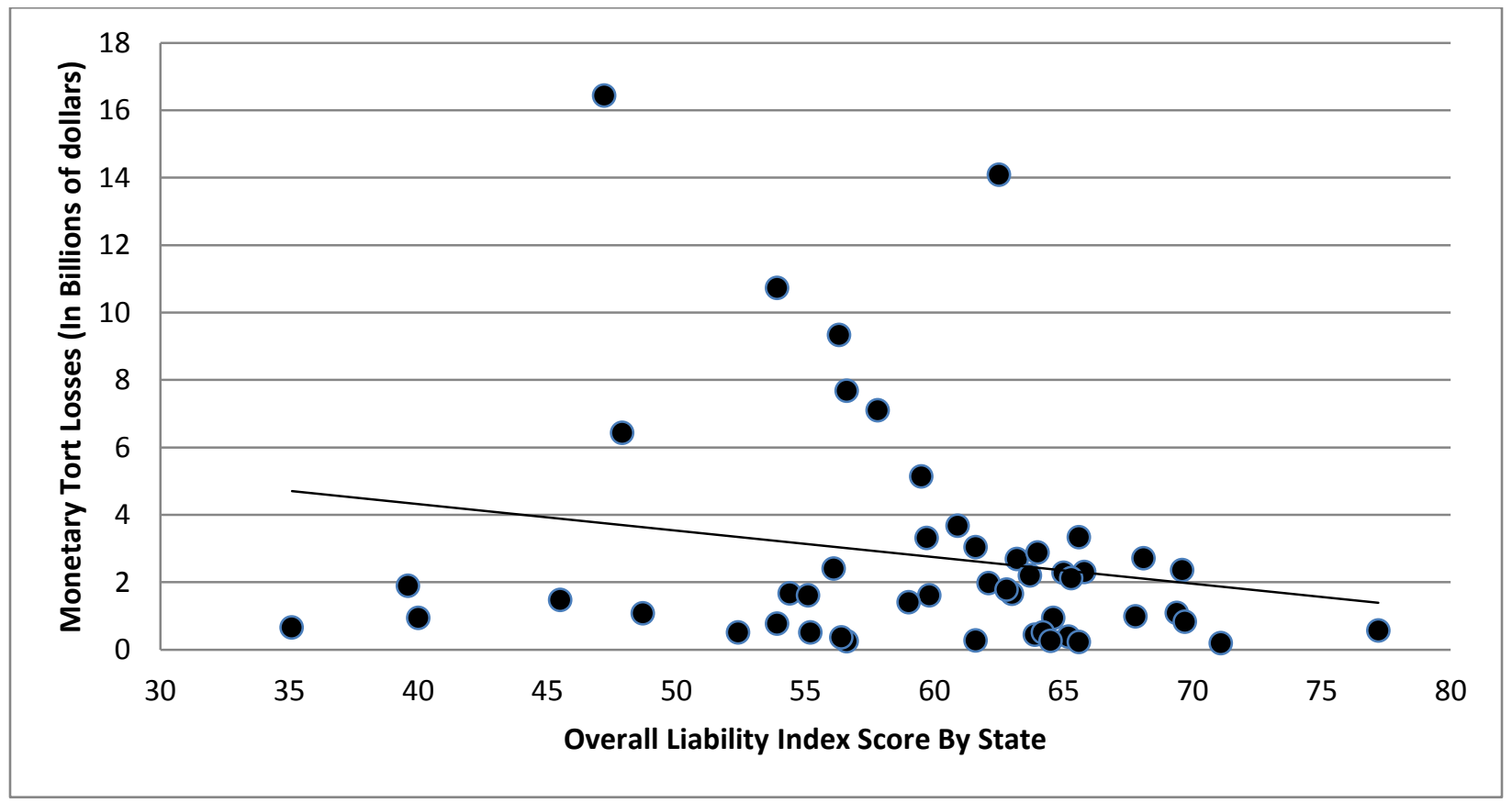

${ }^{12}$ These data on total tort awards by state comes from McQuillan, Lawrence J. and Abramyan, Hovannes. (2010). U.S. Tort Liability Index: 2010 Report. Pacific Research Institute. San Francisco, CA. 
Figure 3.4: Correlation of Total Monetary Tort Losses and Treatment of Tort and Contract Litigation

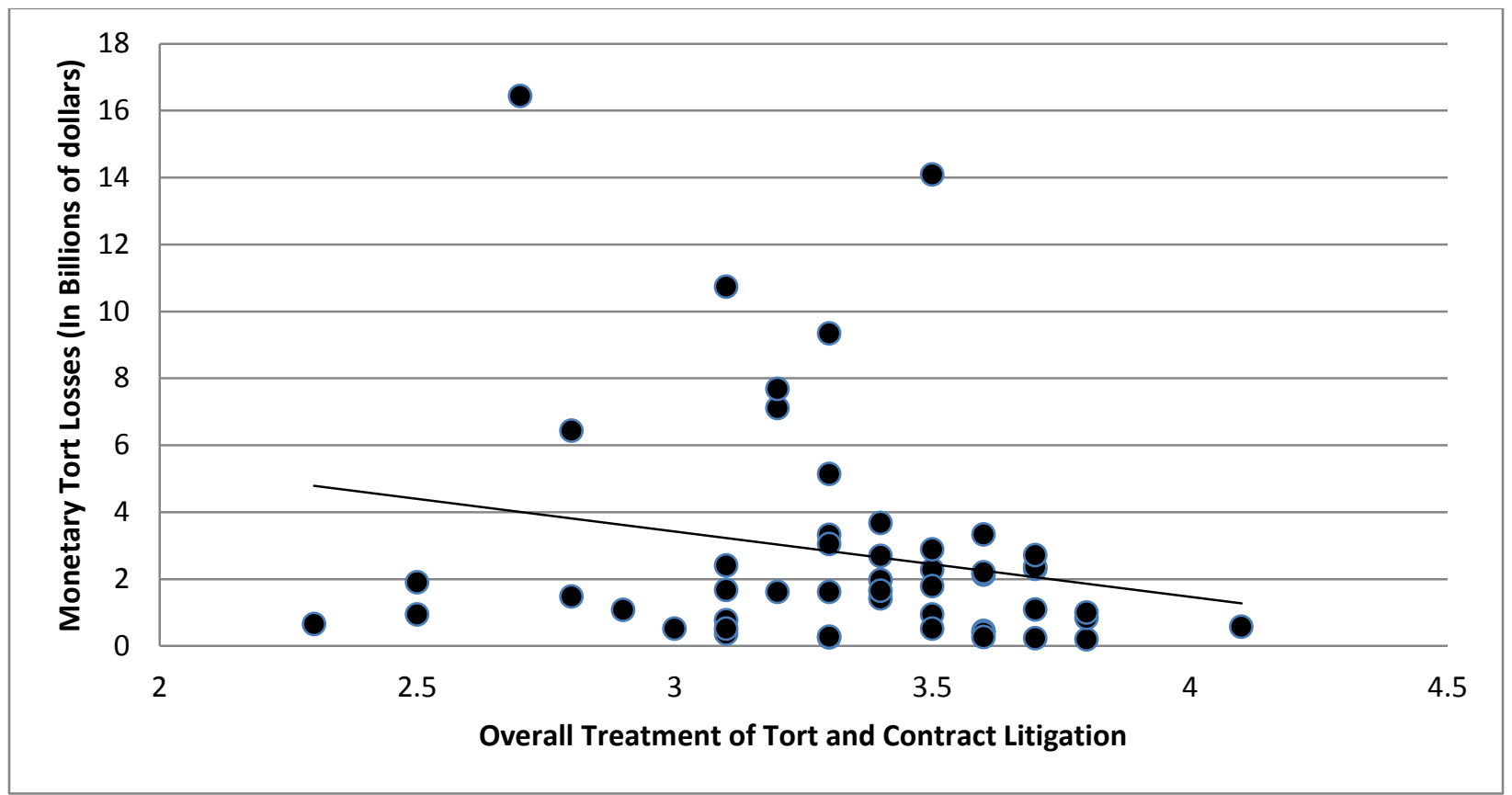

Figure 3.5: Correlation of Total Monetary Tort Losses and Treatment of Tort and Rules of Discovery

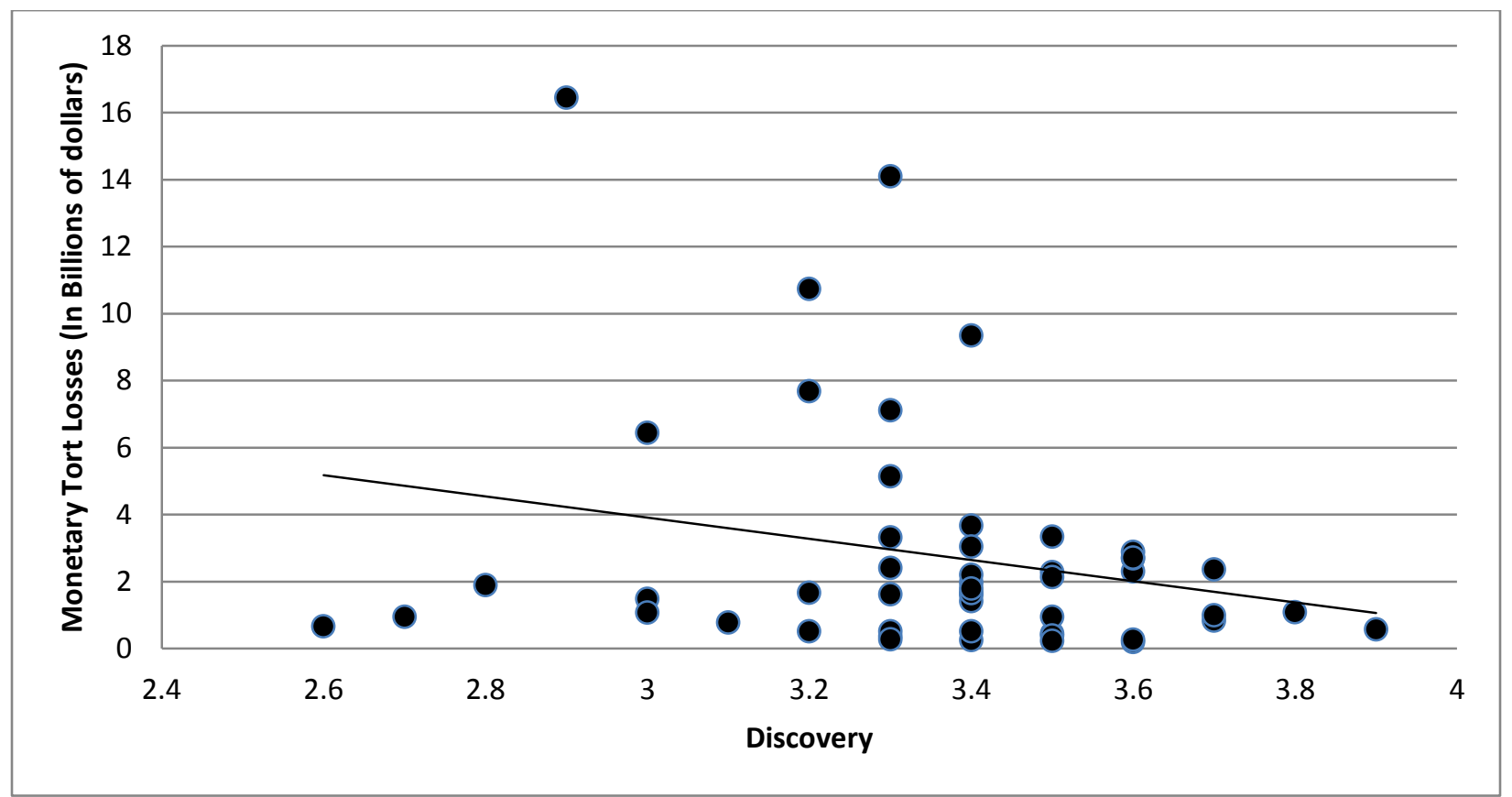


Figure 3.6: Correlation of Total Monetary Tort Losses and Rules Regarding Scientific and Technical Evidence

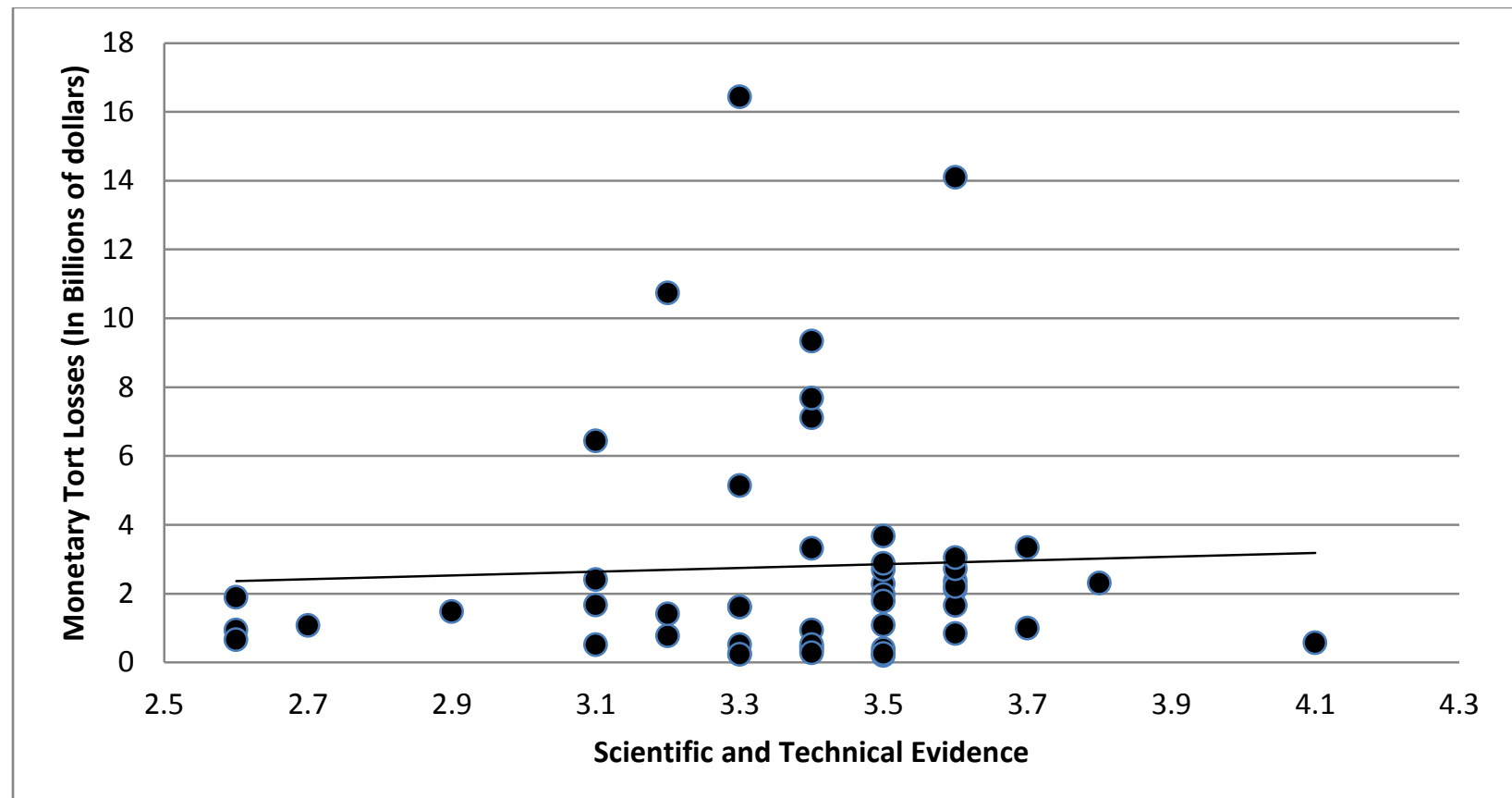

Figure 3.7: Correlation of Total Monetary Tort Losses and Judges' Impartiality

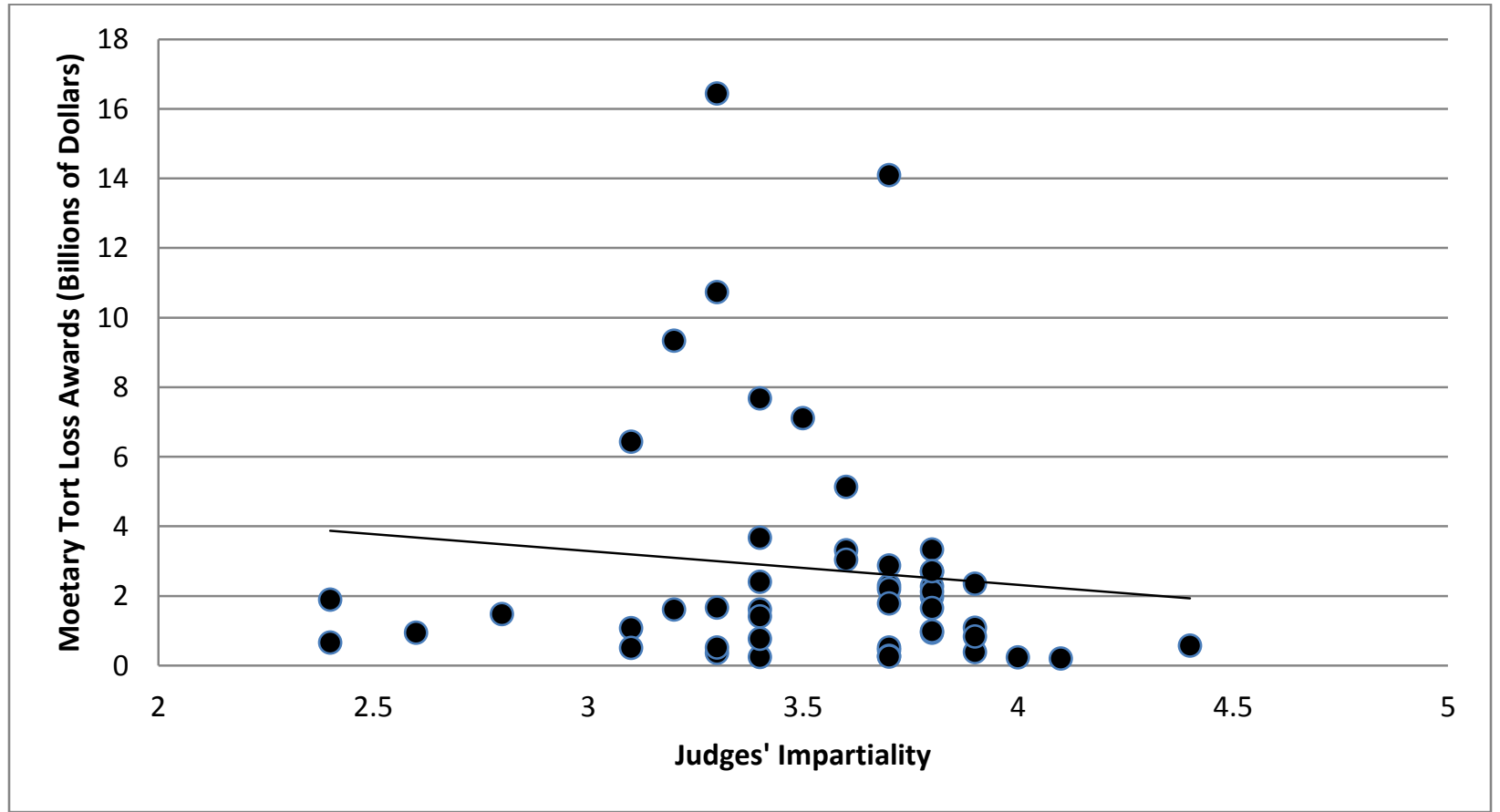


Figure 3.8: Correlation of Total Monetary Tort Losses and Judges' Competence

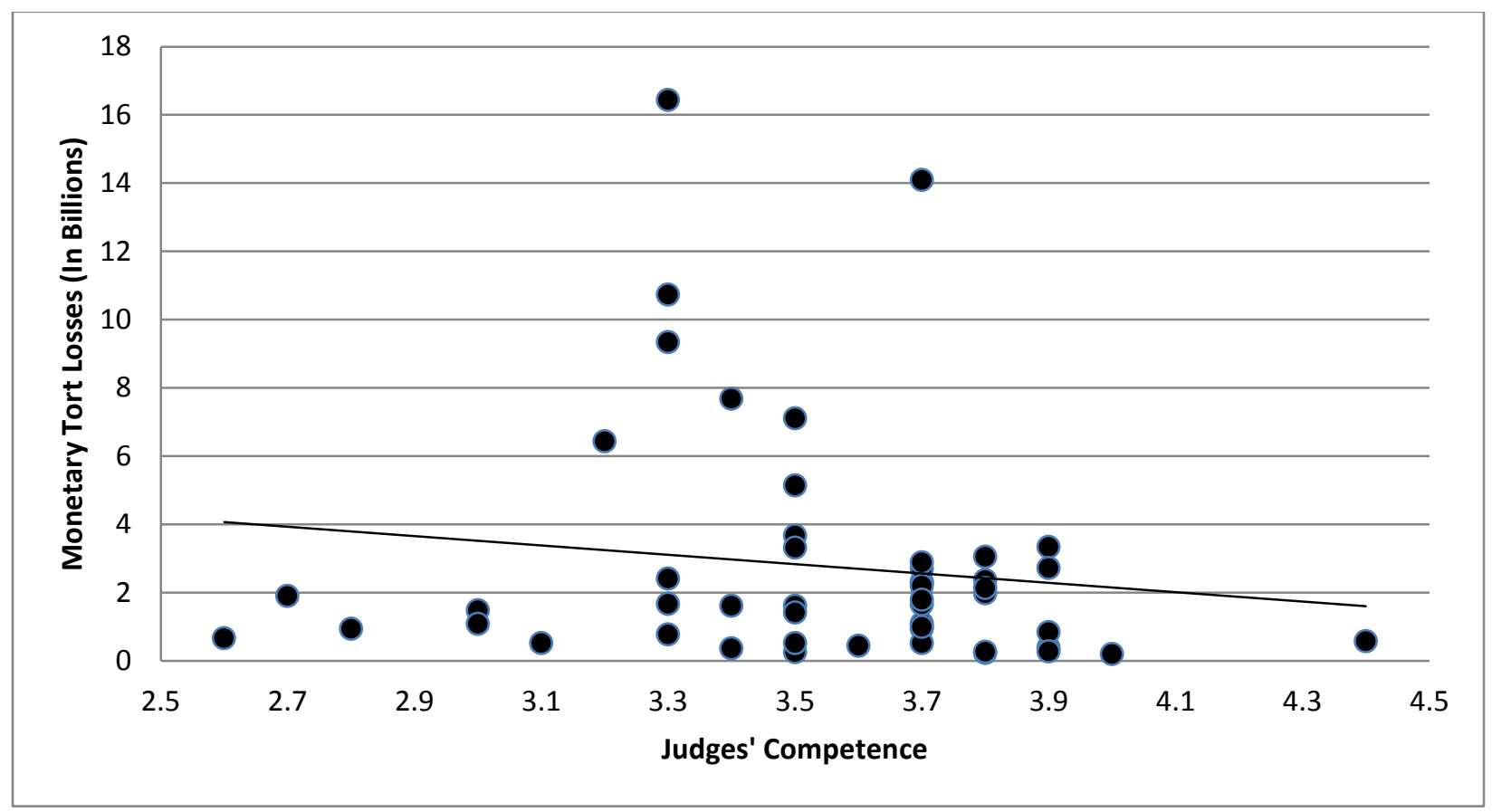

Figure 3.9: Correlation of Total Monetary Tort Losses and Juries' Fairness

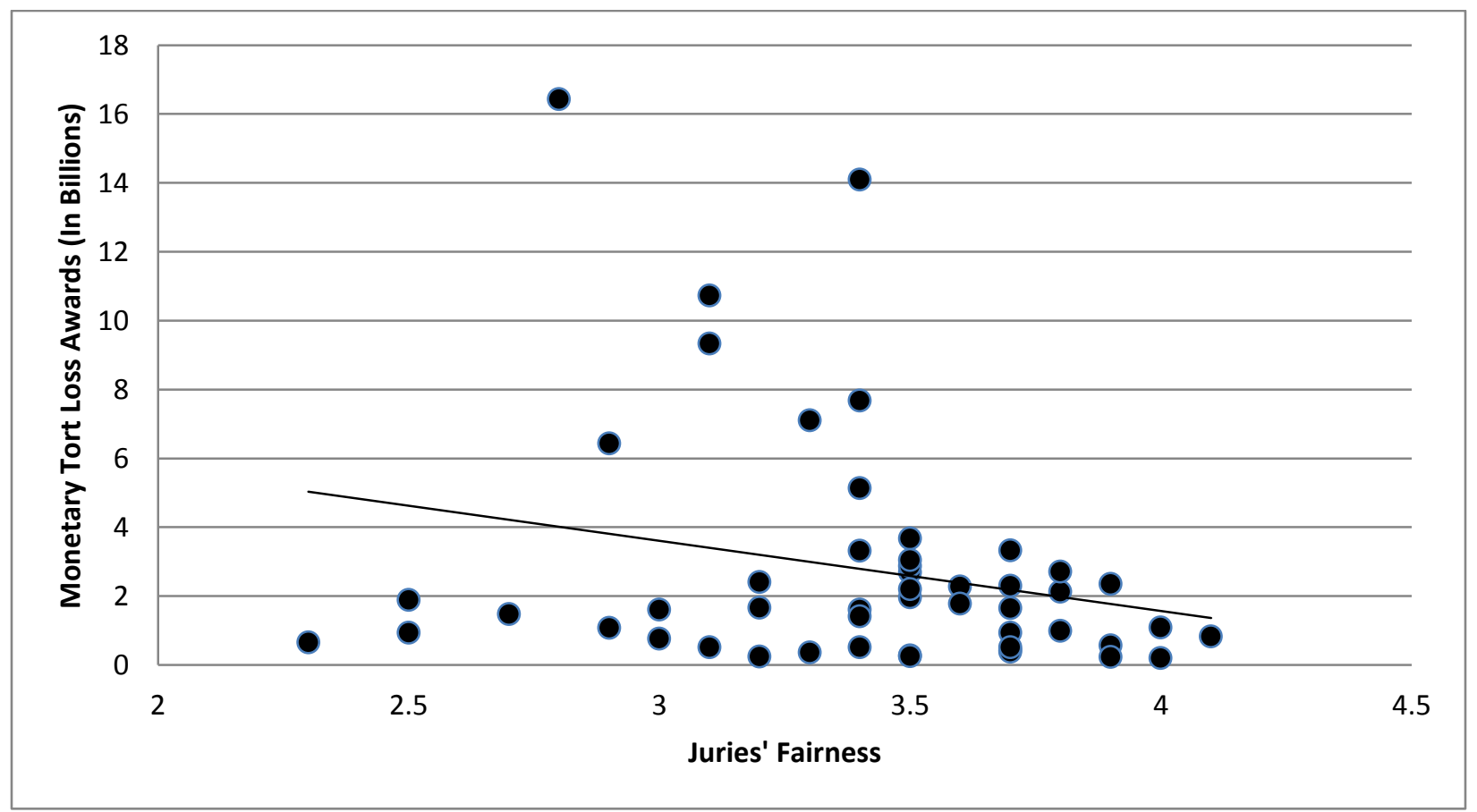


Figure 3.10: Correlation of Total Monetary Tort Losses and Juries' Predictability

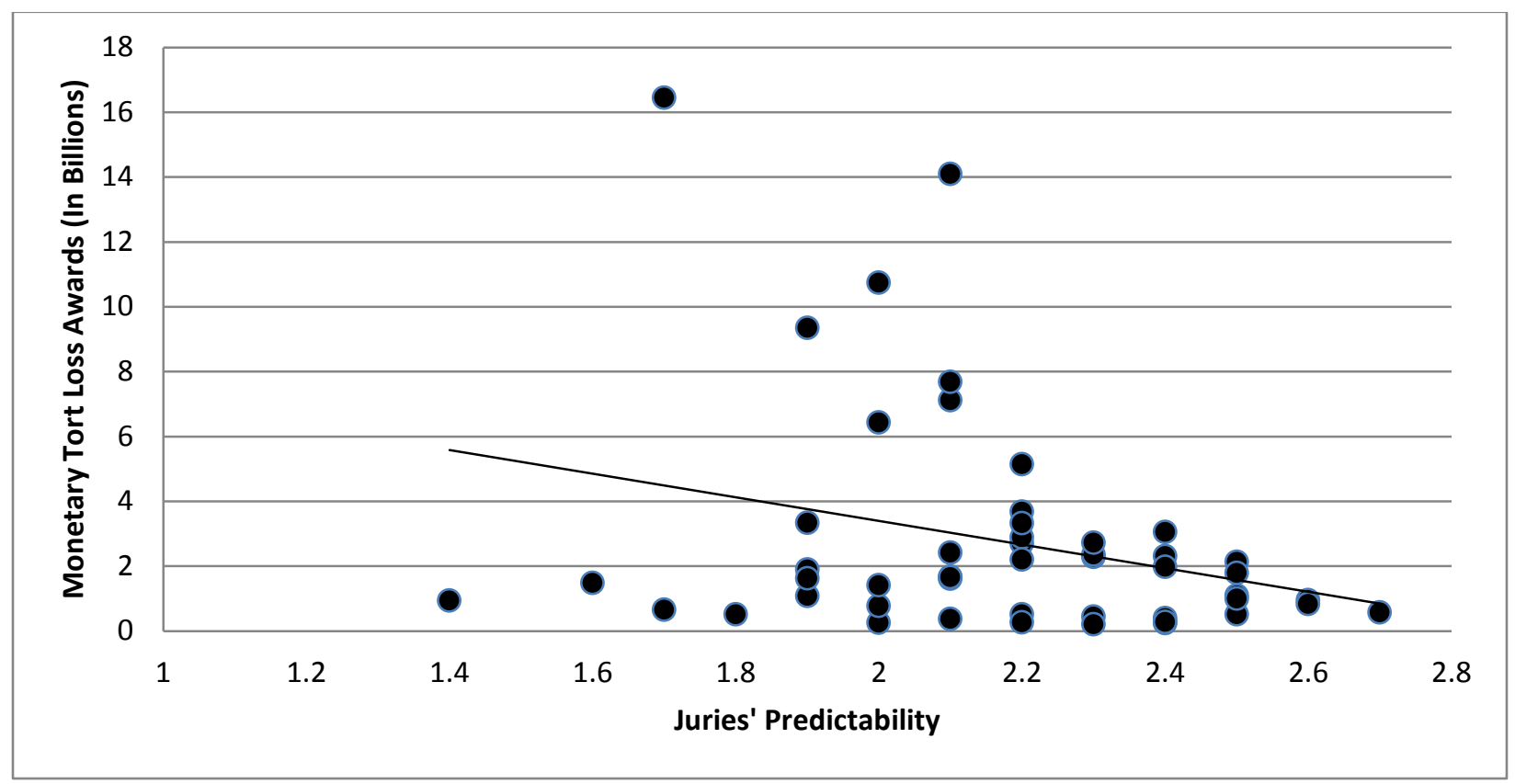

In order to more formally test our conjecture about the impact that legal regimes may have on entrepreneurial and business decisions we ran a set of negative binomial regressions, using the number of Fortune 500 companies incorporated in each state as our dependent variable. The model takes the following form:

$$
\ln L=\ln \left(\frac{e^{-\lambda_{i} u_{i}}\left(\lambda_{i} u_{i}\right)^{y_{i}}}{y_{i} !}\right)
$$

Where $y_{i}$ is the number of Fortune 500 companies incorporated within state $i$ represented as $y_{i}=$ $0,1,2,3, \ldots$, and $\lambda_{i}$ is the number of occurrences within the given space. Here $\lambda_{i}$ takes the form

$$
\lambda_{i}=x_{i}^{\prime} \beta
$$

We include a set of six of the subcomponents that we believe most convey dynamic legal predictability, and also a set of socioeconomic control variables.

We perform regressions using the overall liability system grade and the grades for each of the subcategories we believe best capture what could constitute legal predictability for entrepreneurial activities, along with our control variables for other economic and demographic 
factors that would influence the underlying rate of entrepreneurial and business activity. Our estimates are reported in Table 3.1.

\section{Table 3.1: Number of Fortune 500 Companies Incorporated in State, Negative Binomial Regression Results}

\begin{tabular}{|c|c|}
\hline $\begin{array}{c}\text { Harris Score Area (each } \\
\text { from separate regression, } \\
\text { see Appendix IV for full } \\
\text { regression results) }\end{array}$ & $\begin{array}{c}\text { Impact of One Unit Increase in } \\
\text { Harris Score on the Number of } \\
\text { Fortune 500 Companies } \\
\text { Incorporated in State }\end{array}$ \\
\hline Overall Grade & $7.28^{* *}$ \\
Discovery & $9.82^{* * *}$ \\
Scientific and Technical & $10.24^{* * *}$ \\
Evidence & $7.37^{* *}$ \\
Judges' Impartiality & $7.81^{* *}$ \\
Judges' Competence & $9.16^{* *}$ \\
Juries' Predictability & $6.12^{*}$ \\
\hline Juries' Fairness &
\end{tabular}

Notes: Table presents the estimated marginal effects of only the legal variable coefficients. Statistical significance indicated as follows: $* * *=1 \% ; * *=5 \% ; *=10 \%$.

For both the overall grade (row 1) and each of the subsequent subcategories the results are all positive and statistically significant. The marginal effects for the overall grade suggest that a one-point increase in a state's score leads to an increase of more than seven incorporations within that state. The two subcategories that have the largest impact on incorporations appear to be "discovery" (row 2) and "scientific and technical evidence" (row 3). Both of these suggest that with a one point increase in a state's grade for each of these subcategories, the number of incorporations increases by 9.82 and 10.24 respectively. Further, rows 4 and 5 both refer to the importance of a judges' predictability. Specifically, row 4, judges' impartiality suggests that a one-point increase in that categories' grade increases the number of incorporations by 7.37 while column 5, judges' competence, increases the number of incorporations by 7.81. Most notable, 
rows 6 and 7, juries' predictability and juries' fairness, suggest that a one-point increase in each categories' grade increases the number of incorporations by 9.16 and 6.12 respectively.

These final two distinctions would generally seem to help draw out the distinction we are attempting to make and also the importance of risk and uncertainty (Knight 1921[2005]). Specifically, greater jury predictability would reduce the overall variance associated with judicial predictability and would thus increase, ex-ante, the predictability of future judicial outcomes. Overall, this would reduce future uncertainty regarding judicial precedent and outcomes. Thus, compared to a juries' fairness, predictability within our empirical analysis has the much larger impact, which helps to corroborate what we initially suggested.

Overall, our results give rise to some very important implications. The location of a firm seems to ultimately be driven by the importance of being able to fairly present and use scientific and technical evidence and discovery procedures within the courtroom of a given state. This would seem to comport with our conjecture about the ultimate importance of Schumpeterian entrepreneurial and legal creative destruction. In other words, as we suggested, a firm has any number of legal risks that may be unavoidable. However, the most important for a firm to avoid are those most damaging to a new and never before known technology or technological discovery. Thus, when faced with a legal challenge concerning such an innovation a firm will look to that location which will be most willing to accept the necessary and highly technical evidence derived from these entrepreneurial discoveries. Therefore, it will be those jurisdictions most willing to push the process of Schumpeterian legal creative destruction that will be the ones to see a rise in the number of firms located within that jurisdiction.

Each of the remaining categories give strong evidence that the predictability associated with legal issues and the creation of legal precedent derived from legal action do in some way 
appear to impact the incorporation decision of a firm. More stringent rules of discovery minimize the risk of previously unknown evidence from entering the trial as it progresses. Further, the judge as agenda setter plays a vital role as to how a case actually progresses. Given that, knowing how and why a judge will proceed increases the ability to predict how this dynamic legal creative destruction may play out. Lastly, the jury as the ultimate fact finder will be the body to determine the outcome. Thus, knowing how this may play out also increases the ability for an entrepreneur to predict the direction that any newly derived legal precedent may go.

\subsection{Legal Systems and the Allocation of Entrepreneurial Efforts - Baumol's Productive and Unproductive Entrepreneurship}

Based on the work of Baumol (1990), modern economic literature acknowledges that not all entrepreneurial activities are wealth-enhancing for a society. Creative individuals may spend their time and talents earning wealth for themselves either by producing goods and services for others voluntarily (productive entrepreneurship), or by attempting to secure wealth transfers through the political and legal process (unproductive entrepreneurship). The allocation of entrepreneurship across these two alternatives is driven by the relative payoff or personal reward, which in turn is a function of the incentives created by legal systems. Put simply, an entrepreneurial individual located in one state may have started a cutting edge engineering company, while had she located in another state may have instead started a new personal injury law firm or lobbying firm, depending on the relative profitability of these industries in each state.

From this it is possible to understand that it is the quality of the legal institutions found within a state that will have the greatest impact on the type of entrepreneurship that will develop. When legal systems create a system of economic predation, the prevalence of unproductive 
entrepreneurship will increase (Buchanan 1975; Frye and Shleifer 1997). Thus, it is the quality of the legal institutions and the ability of those institutions to constrain the ability for individuals to undertake such unproductive behavior that plays a crucial role in economic growth, development and wellbeing.

To this point our analysis has applied to all types of entrepreneurship, whether productive or unproductive. In other words, unproductive entrepreneurs also face a bundle of legal risks that must constantly be managed. Further, the same process of creative destruction also occurs within these areas, requiring changes in both the law and legal precedent. Therefore, just as productive entrepreneurs seek out those locations that provide legal predictably, so too do unproductive entrepreneurs. However, this also brings out the importance of horizontal legal federalism, in that through competition the results of unproductive entrepreneurship may over time be minimized.

In this context, areas that provide legal predictability that rewards or encourages unproductive entrepreneurship and economic predation will see declines in overall economic wellbeing and outmigration, or exit, in accordance with Tiebout (1956). If one jurisdiction has legal rules that are detrimental to prosperity, it simultaneously has the unintended consequence of increasing the competitiveness and well-being of entrepreneurs in neighboring states (Weingast 1995). Therefore, under legal federalism there is an automatic check on the extent to which unproductive entrepreneurship might emerge (becoming increasingly strong as the ability to exit occurs), in contrast to a centralized legal system.

In the context of our current work we attempt to understand how exactly changes in a state's liability index score may impact not only economic outcomes, but also the type of entrepreneurship that individuals pursue. In order to do this we consider how a state's liability 
score (the overall score for each state), impacts three key economic indicators for each state. As a first approximation of each, we plot the individual liability rankings against (1) Sobel (2008)'s measure of the ratio of productive to unproductive entrepreneurship in each state (we term this the "Baumol ratio"), (2) the establishment birth rate for large firms in each state, and (3) the number of patents produced in each state. Figures 3.11,3.12, and 3.13 show each respectively.

Figure 3.11: Comparison of Baumol Ratio against State Liability Index

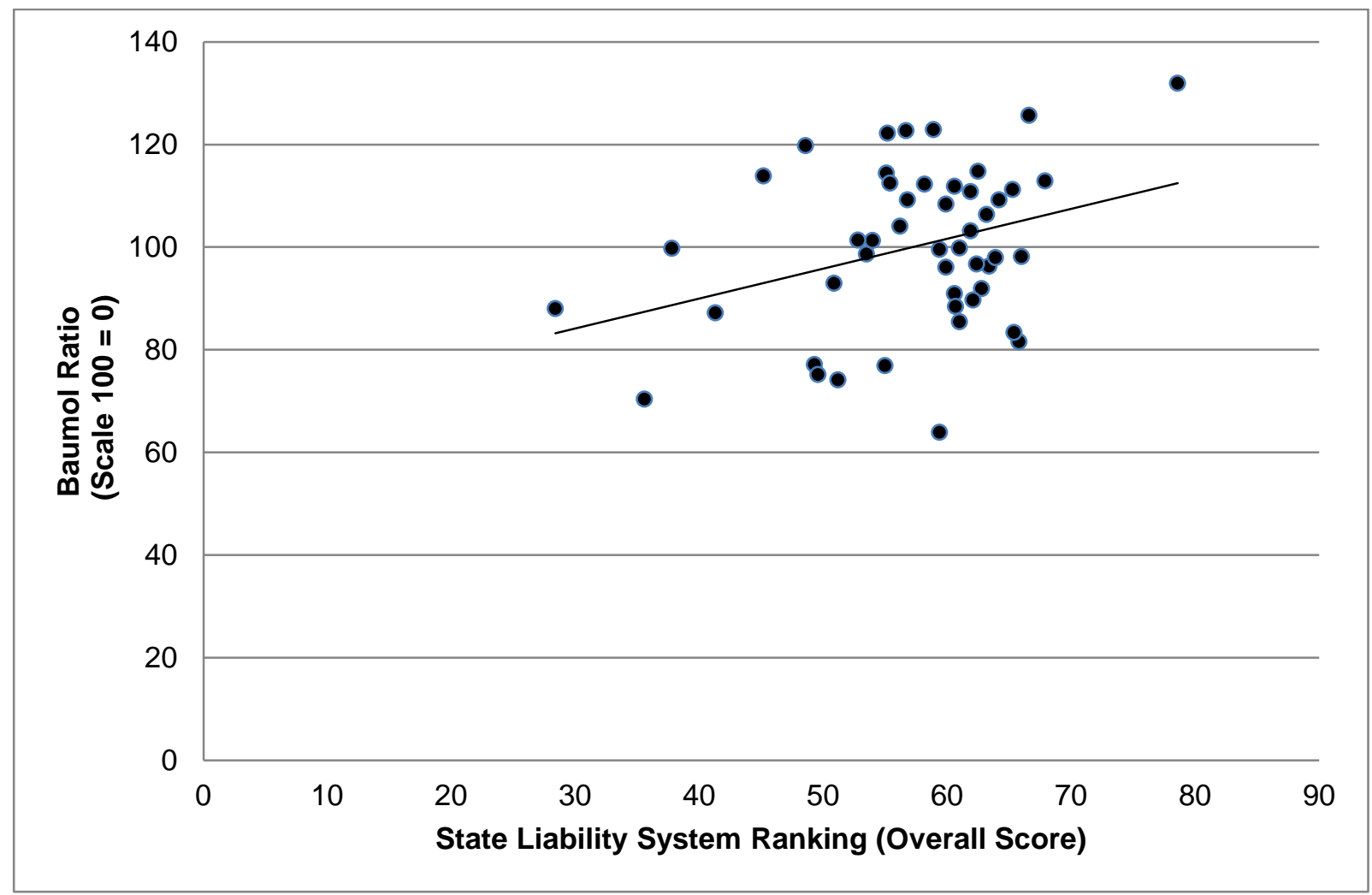

In the figures, there appears to be a strong, positive correlation between a state's legal climate as measured by its liability system rank and the three variables measuring innovation and productive entrepreneurship. Overall, these indicators suggest that states with sounder legal institutions have a larger establishment birth rate for large firms, a larger number of patents produced, and a significantly larger number of productive relative to unproductive entrepreneurs. 
Figure 3.12: Comparison of Large Establishment Birth Rate and State Liability Index

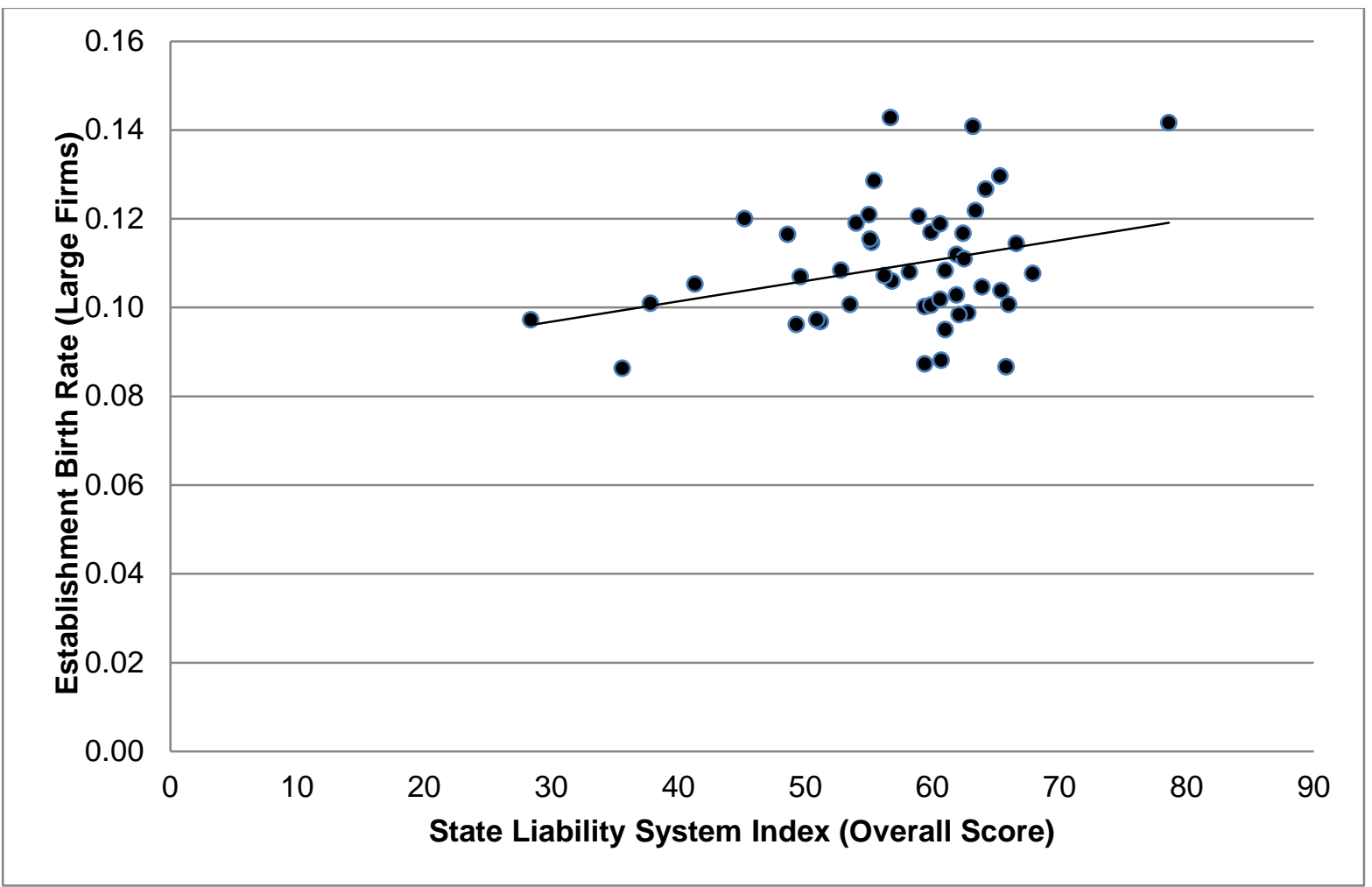

Figure 3.13: Comparison of Patens per Capita and State Liability Index

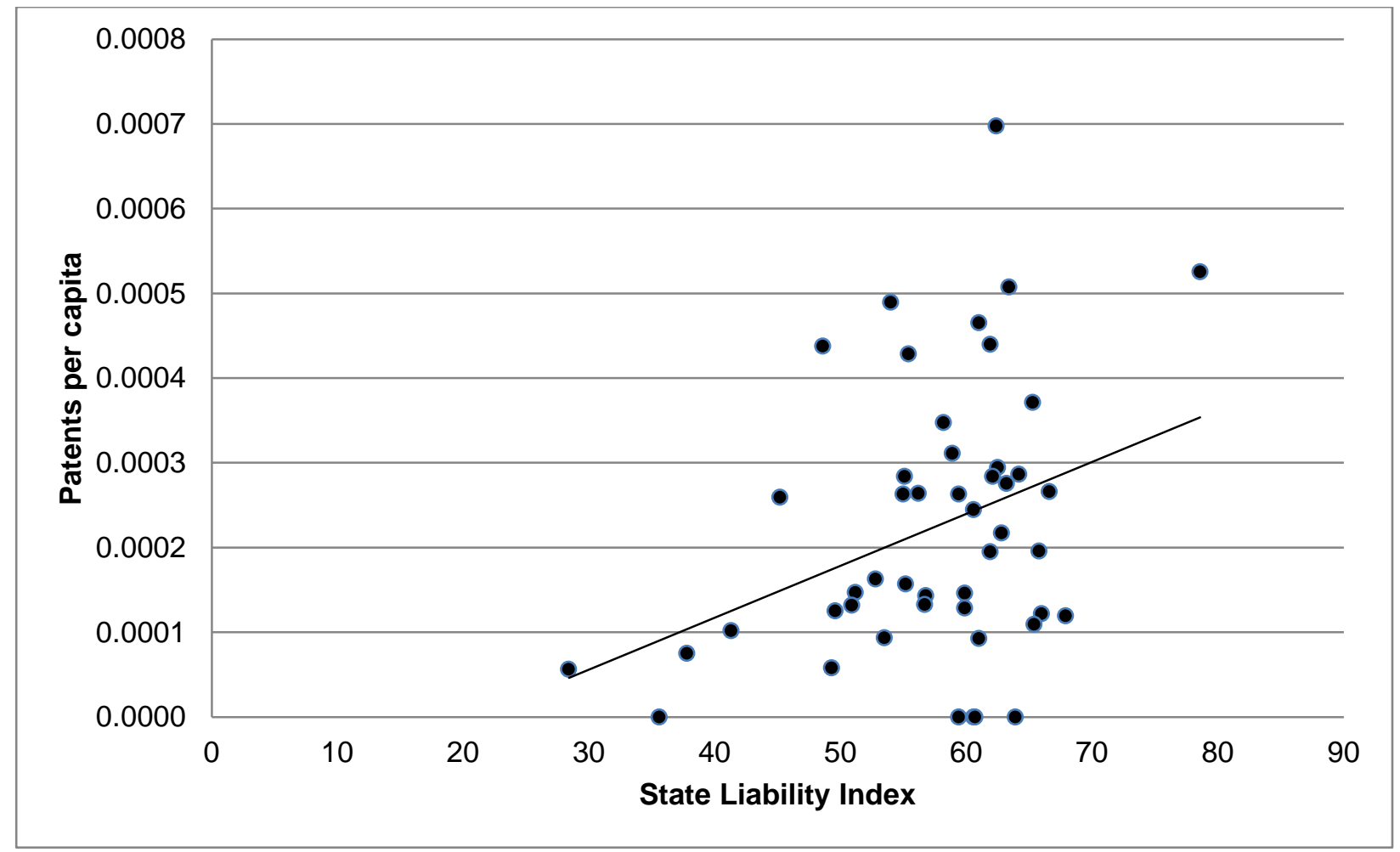


Regression lines fit to these relationships all show positive and significant correlations as is shown in Table 3.2. These results strongly suggest that a sounder legal system in each state appears to reduce the ability for unproductive entrepreneurship to arise, thus leading to greater wealth enhancing activities by individuals and firms.

Table 3.2: Productive Entrepreneurship Measures by State, Regression Results

\begin{tabular}{|l|ccc|}
\hline \multirow{4}{*}{ Independent Variables } & \multicolumn{3}{|c|}{ Dependent Variables } \\
\cline { 2 - 4 } Constant & Baumol & Patents per & Large Firm Establishment \\
& Ratio & 100,000 & Birth Rate (per 100) \\
State Liability Index & 30.51 & 5.96 & $44.62^{* *}$ \\
Median Age & $(0.15)$ & $(0.02)$ & $(2.34)$ \\
& $0.4672^{* *}$ & $4.22^{*}$ & $0.9153^{* *}$ \\
Median Household Income & $(2.04)$ & $(1.59)$ & $(2.04)$ \\
& $-5.77^{* * *}$ & -1.52 & $-0.3560^{* *}$ \\
Per capita Income & $(3.81)$ & $(0.92)$ & $(2.52)$ \\
& $-0.0035^{* *}$ & 0.0001 & $0.0001^{*}$ \\
Population Density & $(2.53)$ & $(0.05)$ & $(1.53)$ \\
& $0.0118^{* * *}$ & 0.0018 & $0.0005^{*}$ \\
Percent College Degree & $(3.98)$ & $(0.57)$ & $(1.88)$ \\
& -0.0165 & 0.0012 & $0.0027^{* *}$ \\
Percent Male & $(1.36)$ & $(0.94)$ & $(2.45)$ \\
& -0.8623 & 0.0266 & -0.0654 \\
& $(1.22)$ & $(0.30)$ & $(0.94)$ \\
& 1.4249 & 0.0177 & $-0.4894^{*}$ \\
R-Squared & $(0.37)$ & $(0.01)$ & $(1.38)$ \\
Observations & & & 0.4000 \\
\hline
\end{tabular}

Notes: Absolute t-statistics in parenthesis. Statistical significance indicated as follows: $* * *=1 \% ; * *=5 \% ; *=10 \%$.

\subsection{Conclusion}

This chapter has attempted to add to the literature on legal federalism by examining the impact that it has on innovation and entrepreneurship. Business firms face different bundles of legal risks that they must manage, some heavily depending on their location some not. This 
proportion will vary widely across different types of businesses, and thus variations in state legal systems will have disproportionate impacts on some types of firms relative to others.

Most importantly, this chapter has tried to bring attention to the idea that the predictability of the evolution and application of law into new areas in a state is a very important determinant of the environment created for entrepreneurial endeavors. Because the Schumpeterian process of creative destruction creates new goods and services to which existing law must be extended, it is a driver of legal evolution. A substantial upfront investment by an entrepreneur in a location will critically depend on how well he or she can forecast the future application of local law onto the new good or service being produced.

Through entrepreneurial creative destruction entirely new bodies of laws must be developed in order to deal with what are entirely new and previously unknown innovations and discoveries. Therefore, we contend that each state competes over these new bodies of law and eventually through the evolutionary process of trial-and-error come to discover certain areas of comparative advantages in which they specialize. This in turn drives entrepreneurs to naturally select into those states that are most conducive to not only Schumpeterian entrepreneurial discover, but also are those best able to cope with potentially uncertain legal contingencies that may emerge due to this process. The returns to entrepreneurial discovery in that field will also be higher in those areas, causing the state's existing resources to naturally flow into those activities in the spirit of Baumol (1990).

As entrepreneurs drive change, legal systems must evolve. A system of decentralized legal federalism is the system best able to cope with this process of the discovery of how to apply existing law into new areas. With multiple jurisdictions attempting to apply law into new areas, those with existing comparative advantages and the best and most efficient systems for dynamic 
legal evolution will succeed and prosper. In turn, this helps to create (or explain) the geographic clustering of entrepreneurial enterprises in certain legal jurisdictions. 


\section{Chapter 4}

\section{Credible Commitments and Constitutional Constraints: State Debt Repudiation and Default in nineteenth Century America}

\subsection{Introduction}

The recent events that have unfolded within the financial sector have increasingly led to significant economic difficulties for the public sector both internationally and domestically. In the United States this has created a depressed situation for many junior and state level governments. Specifically, the financial crisis has resulted in a precarious situation for state budgets and fiscal positions. Most telling of this the online prediction market, In-Trade, has set up markets in the event that the states of California, Illinois and New York would default on their own sovereign debt obligations. ${ }^{13}$

These events have also played out within the federal government through the intense debates and last minute vote involving the debt ceiling and the subsequent downgrade of the U.S. sovereign debt by the rating agency Standard and Poor's. These debates also brought forth discussion of a possible balanced budget amendment to the U.S. Constitution, which has followed in the wake of Spain's recent constitutional balanced budget amendment meant to cope with its increasing sovereign debt problems.

Although neither a state government nor the federal government has defaulted yet, this nevertheless brings to light the relevance and importance of credibly committing a government to pursue time-consistent policy into the future in order to avoid such an outcome (Kydland and Prescott 1977; North and Weingast 1989). In light of the recent financial events and their impact on sovereign governments, this study is an attempt to examine the significance of constitutional

\footnotetext{
${ }^{13}$ Information is freely available at www.Intrade.com.
} 
change and entrenchment as a means for a post-default sovereign state to demonstrate a credible commitment. I do this by analyzing the issue from a historical context when, between 1839 and 1842, the U.S. states suffered through an acute debt crisis resulting in eight states and one territory defaulting on their sovereign debt obligations. Five of these outright repudiated all or part of their outstanding debts. This led to massive upheaval within state governments, resulting in thirteen states drastically amending or adopting entirely new constitutions by 1850 , with another seven states creating explicit constitutional provisions in regard to sovereign debt by 1857. Most of these changes dealt specifically with the issue of sovereign debt, and provided a set of binding constraints which, I argue, conveyed a credible commitment to creditors of a state's willingness to repay all post-default debt obligations.

I examine the impact that numerous constitutional amendments had in the aftermath of state default and repudiation through historical evidence as well as from difference-in-averages and cross-sectional pooled OLS regression analysis using data from the New York Stock Exchange between 1850 and 1860. Overall, I find strong evidence to suggest that those states that adopted a set of constitutional amendments requiring strict limits on the amount and type of debt as well as strict procedural safeguards for the issuance of debt saw a significant increase in their average bond prices relative to those states that did not implement similar constitutional constraints. The results hold for both defaulting and non-defaulting states.

These constitutional limitations seem to have created the necessary commitment for states to again obtain external credit and financing as these constraints, although they did not always totally remove the ability for states to issue debt, made it both extremely difficult to do so and also set strict requirements pertaining to the repayment of that debt. The evidence would suggest that instead of simply statutorily mandating the changes contained within the 
constitutional amendments, states instead undertook the timely and costly process of amending their constitutions, suggesting that it was meant as a means to convey an "over-commitment" to future policy (Rodrick 1989). Finally, I consider these constitutional amendments in the context of today, providing a discussion of the seeming constitutional erosion that has occurred over time within the states of New York, California and Illinois (those states considered the most prone to potential default by In-Trade) and its potential impact on sovereign debt policy in general.

The remainder of the paper is structured as follows: Section 4.2 provides a brief review of the relevant literature. Section 4.3 lays out an historical overview of early American debt history, before and up through the state debt crisis of the early 1840s. It then carries the analysis further by considering the constitutional changes that occurred after the crisis regarding public indebtedness through the late 1840 s and 1850s. This section spells out how these changes may have conveyed a credible commitment regarding future debt obligations. Section 4.4 lays out the empirical examination, results and an interpretation of those results. It also provides an analysis of the current situation faced by sovereign governments as well as potential policy implications. Section 4.5 concludes.

\subsection{A Brief Review of the Relevant Literature}

How to credibly commit a government to a given set of pre-specified policy goals through time has been a frequently considered concept in the literature. Protecting and enforcing property rights, rather than expropriating property, has been one of the most important issues explored (North and Weingast 1989; North 1991; Weingast 1993, 1995; Frye and Schleifer 1997; Frye 2004). Specifically, the problem becomes one of setting up an institutional framework that minimizes the risk of expropriation by a government or sovereign. In other words, a government 
must find a way to convey a specific commitment to individuals that it will protect rather than confiscate private property.

In general, two means have been suggested by which a government may actually commit itself to a given policy into the future: (1) through precedent, by conveying its commitment to the policy based on adherence to it in the past; and (2) through a set of binding constraints or rules making it impermissible to violate the given commitment (North and Weingast 1989). Although reputational effects created by the first policy can theoretically convey a credible commitment (Barro and Gordon 1983; Diamond 1989), it has been suggested that in reality, as erosion of political constraints emerges, it makes breaching the commitment inevitable, or at least far less costly (North and Weingast 1989).

This suggests that some set of binding constraints must be erected that force a sovereign or government to credibly commit to the desired policy. Scholars have suggested that by establishing institutional constraints through some type of higher or constitutional law, and thus divorcing general debate over the proposed commitment from the everyday political marketplace, a country more rapidly reaps the fruit of economic growth (Elkins, Ginsburg and Melton 2009). As the commitment moves to this higher order, constitutional law, it increases the probability that it will become both binding and self-enforcing, as it may create a set of incentives necessary for political actors to better respect the constraint moving into the future (Weingast 1995).

In a similar vein, Kydland and Prescott (1977) argue that binding rules are necessary in order to credibly commit governments to long-term, time consistent policies. Specifically, the issue becomes one of creating an environment in which economic actors are able to formulate expectations about future policy outcomes. Overall, this requires political actors to announce an 
initial set of credible policy goals, which allows individual actors to set up the necessary expectations to carry forward into the future, thus leading to sustainable and predictable outcomes.

A further path to creating credible commitments is to find the means by which to create a set of incentives that provide the necessary foundation for political leaders to build long-term reputations (Myerson 2007). In this manner, it has been suggested that a system of federalism creates the very incentive for both reputation building and also for the creation of time consistent policies (Weingast 1995; Wibbels 2003). Essentially, the discipline created by interjurisdictional competition checks governments and political leaders from deviating or breaching previously agreed upon promises, as doing so could provide neighboring jurisdictions a competitive advantage and may cause citizens to simply "vote with their feet" and exit the jurisdiction (Tiebout 1956; Inman and Rubinfeld 1997).

A more serious concern is how to recommit to a given policy or goal once a government reneges on its prior arrangements. One feasible means to return to a steady-state equilibrium is for a government to "over-commit," or overshoot future policy goals (Rodrick 1989). In this way, a government signals to economic actors its willingness to bind itself even further than might be necessary, as opposed to a government that would prefer to again renege on its prespecified agreements. Thus, over-commitment by a government after defection may send the necessary signal of its credibility to individuals within the marketplace.

It is within this context that we observe the situation of the American states during the debt crisis between 1839 and 1842. Many had defaulted or outright repudiated and were heavily penalized for that decision either through no access to capital markets or access at extremely high prices. However, the necessary incentives were also in place to push these states to bind 
themselves in a much more forceful fashion than had been previously needed. As such, these states quickly self-imposed new constitutional constraints in order to rebuild their reputations and to send the necessary signal of credibility to both foreign and domestic capital markets that those very governments again would adhere to long-term, time consistent policy. The next section provides an historical overview and examination of the credibility issues at hand.

\subsection{A Brief History and Constitutional Analysis}

Unprecedented economic growth began in the latter half of the 1820s and continued well into the 1830s in the United States. Over this period, there was also a large influx of public aid that poured into the economy from various state governments. Much of this public assistance came as a direct result of the initial success with New York's foray into the construction of the Erie Canal. This success led many state governments to provide massive public support for both internal improvements (generally railroad and canal projects) and banking institutions, the latter again driven by the success of New York's investments in many of its own banks. For instance, by the 1820 s New York was earning more than $\$ 100,000$ a year from the dividends paid out by the banks in which it had invested (Wallis, Sylla and Grinath 2004). This encouraged many other states to pursue a similar course, most notably in the South, as bank investment was considered a relatively low-risk investment that provided a potentially large return. For example, when Louisiana chartered the Union Bank in 1832, the British financial firm, Barings, purchased the entire state bond issue at a large premium, with the expectation that the bank would net a handsome return (Wallis, Sylla and Grinath 2004).

Generally, it was the southern states that would invest in banks, while northern states largely targeted funding toward internal improvements (Ratchford 1941). In order to finance 
these undertakings states began implementing systems of "taxless finance" whereby instead of resorting to direct taxation (most states at this time had no direct taxes levied on citizens), states would issue large amounts of debt. The proceeds of these sales, if sold at a premium, would be used to cover interest payments as they came due, or would simply issue more debt in order to cover interest payments otherwise (McGrane 1933; Ratchford 1941; Wallis 2000). In this manner, state governments hoped to avoid the need to tax citizens in order to finance these projects and to then wait for the completion of those projects to become profitable, thereby paying down the debt incurred with those proceeds (Ratchford 1941). Further, ever-rising land values throughout the 1830s also increased the desire for debt funded investments in internal improvements and banking institutions as, in the extreme, it was believed that states had a more readily available taxable base, real property, in the event that difficulties arose in meeting debt obligations (Wallis, Sylla and Grinath 2004). Overall, between 1830 and 1840 total indebtedness of the states incurred to finance banking institutions and internal improvements had increased by almost \$178,500,000 (Porter 1880).

Most telling of this growth in public indebtedness, of the nine states that eventually fell into the most dire financial situations, for eight of them, Pennsylvania, Maryland, Indiana, Illinois, Michigan, Arkansas, Florida and Mississippi, total indebtedness in 1830 was just under $\$ 7,000,000$, ballooning to almost $\$ 95,000,000$ by 1840 (Curtis 1844 ). Although for a time this system of "taxless finance" remained sustainable, the first signs of what was to come began with the onset of the panic of 1837 , when many states, especially those in the West, had just begun passing legislation to finance their own internal improvements.

Newer states in the West and South had invested large sums in state-sponsored endeavors and were placing large bond issues into the market. During the first half of the 1830s westward 
expansion and increases in economic activity had led to ever increasing land values, with the value of real estate rising by $150 \%$ between 1830 and 1837 (McGrane 1965). However, this increase in land values was slowed first in July of 1836 with the passage of President Andrew Jackson's Specie Circular, which required payment in specie for all public land sales. This legislation was coupled with a tighter credit policy adopted by the Bank of England and a downturn in cotton prices in the United States which culminated in the panic of 1837 . The result was a general suspension of specie payments by banks throughout the country for nearly a year (McGrane 1965). Overall, the panic by-and-large did not exclude states from external credit sources; however, it did require that many times they accept discounts on the bonds they did issue. $^{14}$

Although the panic of 1837 created a small setback and should have sent a warning signal to state legislatures, it was short-lived. By 1838 the economy had begun to rebound and states continued to pour debt funded aid into the economy. Specifically, between 1837 and 1841 well over half of the nearly $\$ 200$ million in outstanding state debt was incurred (Kim and Wallis 2005). Unfortunately, a much more severe depression beset the country in 1839 , lasting into 1842.

Whereas the panic of 1837 disproportionately affected banks within New Orleans and the Northeast, the crisis of 1839 was more focused within the banking industries of the southern and western states (Wallis 2001). Unfortunately, it was states in these regions that were relatively heavily invested in their banking institutions as compared to the rest of the country. Thus, whereas the panic of 1837 had a much smaller effect on state fiscal positions, the crisis of 1839

\footnotetext{
${ }^{14}$ Although the causes and consequences of the panic are still debated today and would require work well beyond the scope of this paper to fully explain them, it is known that most of the sovereign borrowing that did occur through this period happened between 1837 and 1841. Thus, this would suggest the Panic of 1837 affected banking much more so than sovereign debt. In fact, it appears that Maryland, which placed an $\$ 8$ million loan on the market in the middle of the panic, was the only state unable to find a ready buyer for its bonds.
} 
proved otherwise. With western and southern banks financially constrained, state fiscal positions became much tighter, which rapidly led to a downward spiral as bank failures led to sovereign debt problems.

It was over this period that many states found themselves in financially precarious positions or, for a number, became financially insolvent. By 1842, most states had halted all internal improvement projects, realizing they were either unprofitable or unobtainable. Many of the state banks, whose capital was backed by the credit of their respective state, became insolvent and subsequently dissolved, leaving those states directly liable for all outstanding debts that had been incurred.

As a result of these events, by 1842 eight states and one territory defaulted on their interest payments, with five partially or outright repudiating their debt obligations. These events unfolded in 1841 first when Pennsylvania delayed interest payments, followed by Indiana, Florida and Mississippi all defaulting. This led to serious concerns within the sovereign debt market and a subsequent domino effect as Arkansas and then Illinois, Maryland, Michigan, Louisiana and finally Pennsylvania fell into complete default (Ratchford 1941). Of those states, Florida, Mississippi, Arkansas, Michigan and Louisiana either totally or partially repudiated their debts. The states that remained solvent were only able to do so by curtailing state subsidization of their internal improvement projects, by imposing new taxes on their populous, by placing new debt issues on the market at heavy discount, or through some combination of the three (Wallis 2005). For example, in 1842 New York passed its "stop-and-tax" legislation which indefinitely halted all internal improvement construction in the state and also placed a one percent tax on all taxable property. 
Over the next several years states were forced to take drastic action and abandon many of the projects they had initially started in the 1830s; sell off large portions of those projects to private interests (as in the case of Michigan and Indiana); attempt to restructure their outstanding debts with creditors (Indiana and Illinois); and/or impose new statutory tax laws on the populous within those states, generally through increased property or poll taxes, in order to fund their external debt obligations (Wallis 2000).

The direct result in the aftermath of this debacle was a complete revulsion against internal improvements in many states (Goodrich 1950). This led to calls for new constitutional measures to deal directly with the issue of state indebtedness. In effect, these became the first set of constitutional debt limitations that states imposed on themselves in American history. Many prominent figures within the states made reference to the importance of restricting state debt through constitutional and legislative change. For example, then Democratic governor of Indiana, James Whitcomb, in his message to the legislature of 1848 suggested:

It is also to be desired that the constitution should be amended, as to prohibit the creation of any public debt, except under restrictions as to amount, and object. Years of prosperity may cause the severe lesson we have been taught on this subject to be forgotten, and we cannot too strongly guard against a recurrence of similar improvidence.

Akin to this, in principle and policy, would be an amendment requiring, for the passage of every bill granting money from the treasury, or public property to individuals, a majority of two-thirds, in each house, of all the members elected. (House Journal 1849).

This was also echoed by the Democratic party platform in the state, when on January 8 , 1849 the first resolution passed by the party was a complete prohibition on the contracting of debt, unless full appropriations were to be made simultaneously in order to pay down both interest and principal, and only after the proposal was met with the approval of the citizens of the state (House Journal 1849). These proposals were not just partisan issues at the time; the state's Whig platform echoed that of the Democratic Party. The Whig position was a complete 
prohibition on the state from ever contracting debt, unless it met the approval of a majority of the citizens of the state (House Journal 1849).

Not only were calls for such measures found across parties, they also cut across states in regard to both the debt issue and constitutional change. In Maryland, as early as 1840 calls were made to rein in spending and find ways to pay down the outstanding debt. For example, then Democratic governor William Grason in his annual messages stated:

I do not perceive how [the redemption of the public debt] can be effected, without resisting the further issue and hypothecation of State stock; reducing the public expenditures by a rigid system of economy, and increasing the revenue by a moderate tax on real and personal estate, till it is sufficient to pay the interest, and leave a small surplus to be applied to the principle of the debt. (House Journal 1840).

These measures were similarly called for within the state until the eventual constitutional changes that emerged.

Further, John J. Crittenden, the Whig governor of Kentucky and eventual Senator of the state, in his message of 1848 not only strongly supported a constitutional convention, but also suggested that measures be put in place that would carry forward efforts that had been implemented to extinguish the debt and grow the economy:

The course of legislation for the last few years indicates, clearly, the popular will that nothing should be done to diminish the power of the State to redeem, at maturity, her out-standing bonds, and to meet, with unwavering promptness, every payment of interest at the places and times when and where they may fall due... and [I] will not take it upon myself to recommend any measure that may hazard that sound principle - a principle as important for the good name of a State as of an individual. . . To your better judgments, however, such subjects may be more properly submitted, and it is not appropriate to my office to say any thing more than to promise my hearty co-operation in any measures that will promote the general interest without encroachment upon the resources that are necessary to extinguish liability already incurred. (Senate Journal 1848).

Finally, Silas Wright, former Democratic governor of New York and strong supporter of

the state's proposed constitutional amendments, suggested in his annual message that

The recent free use of the public credit, in over-hastening loans for State works, and in lending to irresponsible corporations, the embarrassed condition of our finances, and the consequent call for direct taxation to restore public confidence, have doubtless given rise to these proposed [constitutional] amendments. (Senate Journal 1845).

Indeed, it would appear that the issue of New York's indebtedness was a driving factor for the constitutional convention (Galie 1991). In fact, the state's constitution of 1846 had twenty-two 
provisions that specifically restricted the legislative powers over taxation, the appropriation of money and several other similar subjects (Galie 1991). Overall, this anecdotal evidence would at least suggest that constitutional change tied to public finance were major issues through the 1840s not only across state lines, but party lines as well. Further, the issue of state finances and debt, if it was not the primary reason was a major reason cited for the constitutional conventions of the 1840 s and 1850s.

In total, twenty states between 1840 and 1860 adopted some set of new constitutional constraints that had explicit measures dealing with public indebtedness. As suggested, I argue that these constitutional constraints conveyed the necessary credible commitment to creditors regarding a state's propensity to repay any future debt incurred post-crisis and post-default. This was especially important for those states that had defaulted or even repudiated some portion of their debt obligations.

Although the constitutional amendments that emerged varied slightly in degree and scope among states, four were relatively consistent. Specifically, the first amendment was a constraint on the lending of the individual state's credit to a private interest or corporation. As noted, many states, especially those located in the South, had guaranteed the debt incurred by numerous banks and other corporate bodies. For example, in 1833 the then Territory of Florida chartered the Bank of Pensacola. As part of the charter, the bank was authorized to issue $\$ 500,000$ in bonds, which were subsequently endorsed and backed by the credit of Florida (Scott 1893). In return, the state received both mortgages as collateral in the event of liquidation as well as regular dividend payments. However, by 1843 , due to overinvestment in several railroad operations, the bank became insolvent and soon after was liquidated. This left the Territory of Florida fully responsible for the outstanding debt of the bank. Rather than pay the creditors of the bank, as 
stipulated in the original charter, the territory simply reneged on its agreement and repudiated the debt. This practice was also carried out by Mississippi, Arkansas and Louisiana when several of their respective banking institutions followed a similar path.

The second major constitutional change that numerous states adopted was a prohibition on the purchase of private, corporate stock. Many debt issuing states had originally stipulated that any bonds they placed on the market could not be sold below par. However, when market conditions prevented a sale at or above par, states would simply exchange those bonds at par for corporate stock or bonds of various internal improvement companies (Ratchford 1941). The logic being that as the internal improvements became profitable these states would be able to tap those firms as a self-sustaining revenue source (much as the Erie Canal had done for the state of New York) and from this pay off any remaining outstanding debt. Unfortunately, as those corporate bodies failed during the crisis and the internal improvements never materialized, it left many states with no revenue source to pay down the outstanding debt.

The third major constitutional change that I consider is whether a state implemented a specific voting procedure before it could issue debt. Prior to the crisis most states only required a simple majority of both houses of their respective legislatures to vote in the affirmative along with a gubernatorial signature in order to issue debt. However, after the crisis many states implemented radically different voting procedures, which mandated a supermajority of both houses of a state's legislature, a majority vote of the general population, or both before a state could issue debt. This radically altered the ability to issue debt by making it much more difficult and politically costly to do so. For instance, Illinois' Constitution not only required a two-thirds vote of both houses of the legislature in order to issue any debt, the total debt that could be issued 
in one year could not exceed $\$ 50,000$ unless it was for war purposes or if, at a general election, a majority of the state's citizens voted to authorize a larger issue.

The final constitutional amendment I consider is whether a state imposed a time limit on the repayment of debt. Prior to the crisis no state had a statutory limit on the time to repay its debt, although the majority of debt issued over the period was generally payable after twenty, thirty, or forty years depending on the issue and the state (Ratchford 1941). However, these amendments severely restricted how long a debt could remain outstanding, which greatly reduced the uncertainty inherent in longer-term debt issues. For example, Maryland stipulated that both interest and principal were to be repaid within fifteen years, whereas prior to that the state had no repayment requirements.

Table 4.1 provides a list of each of the states that imposed some or all of these constitutional restrictions at some point between 1840 and 1860. As can be seen from the table, thirteen states had adopted a combination of these amendments on or before 1850, with the remaining states doing so at some point after. Thus, a large number of states actually adopted many of these amendments at a time when, although they may not have been under a state of default, several other states (including Illinois, Indiana and Maryland) were. From this it would appear that signaling credibility to both foreign and domestic credit markets may have been a main concern for many of these states. Overall, I conjecture that if these constitutional amendments did in fact provide the necessary credible commitment to potential creditors into the future, then they would have a clear positive impact on a state's bond prices. Therefore, I next test this conjecture under a number of specifications to see the impact that these constitutional amendments may have had on state debt and bond prices. 
Table 4.1: Constitutional changes imposed by state and year between 1840 and 1860.

\begin{tabular}{|c|c|c|c|c|c|c|}
\hline \multirow[b]{2}{*}{ State } & \multicolumn{6}{|c|}{ Amendment } \\
\hline & $\begin{array}{c}\text { No Lending } \\
\text { Credit }\end{array}$ & $\begin{array}{c}\text { No Purchasing } \\
\text { Stock }\end{array}$ & $\begin{array}{l}\text { State Debt } \\
\text { Limits - } \\
\text { Voting } \\
\text { Procedure }\end{array}$ & $\begin{array}{c}\text { State Debt Limits - } \\
\text { Time Limits on } \\
\text { Repayment }\end{array}$ & Default & Repudiate \\
\hline Michigan & 1850 & 1850 & 1843 & & $\mathrm{Y}$ & $\mathrm{Y}$ \\
\hline Louisiana & 1845 & 1845 & 1845 & & $\mathrm{Y}$ & $\mathrm{Y}$ \\
\hline New York & 1846 & & 1846 & 1846 & $\mathrm{~N}$ & $\mathrm{~N}$ \\
\hline Illinois & 1848 & & 1848 & & $\mathrm{Y}$ & $\mathrm{N}$ \\
\hline California & 1849 & 1849 & 1849 & 1849 & $\mathrm{Y}$ & $\mathrm{N}$ \\
\hline Kentucky & 1850 & & 1850 & 1850 & $\mathrm{~N}$ & $\mathrm{~N}$ \\
\hline Virginia & 1850 & & & 1850 & $\mathrm{~N}$ & $\mathrm{~N}$ \\
\hline Maryland & 1851 & 1851 & & 1851 & $\mathrm{Y}$ & $\mathrm{N}$ \\
\hline Indiana & 1851 & 1851 & & & $\mathrm{Y}$ & $\mathrm{N}$ \\
\hline Ohio & 1851 & 1851 & & & $\mathrm{~N}$ & $\mathrm{~N}$ \\
\hline Pennsylvania & 1857 & 1857 & & & Y & $\mathrm{N}$ \\
\hline New Jersey & 1844 & & 1844 & 1844 & $\mathrm{~N}$ & $\mathrm{~N}$ \\
\hline Rhode Island & 1842 & & 1842 & & $\mathrm{~N}$ & $\mathrm{~N}$ \\
\hline Texas & 1845 & 1845 & 1845 & & $\mathrm{~N}$ & $\mathrm{~N}$ \\
\hline Iowa & 1846 & 1846 & 1846 & 1846 & $\mathrm{~N}$ & $\mathrm{~N}$ \\
\hline Wisconsin & 1848 & & & & $\mathrm{~N}$ & $\mathrm{~N}$ \\
\hline Maine & 1848 & & & & $\mathrm{~N}$ & $\mathrm{~N}$ \\
\hline Kansas & 1855 & 1857 & 1855 & 1855 & $\mathrm{~N}$ & $\mathrm{~N}$ \\
\hline Minnesota & 1857 & & & & $\mathrm{~N}$ & $\mathrm{~N}$ \\
\hline Oregon & & 1857 & & & $\mathrm{~N}$ & $\mathrm{~N}$ \\
\hline
\end{tabular}




\subsection{Data, Methodology and Analysis}

\subsubsection{Data and Model Specification}

In order to further analyze the impact that these constitutional amendments may have had I have compiled bond price data from a number of sources between 1850 and 1860 . The first comes from Sylla, Wilson and Wright (2006). ${ }^{15}$ These data provide comprehensive price quotations for the largest domestic markets of the time. Specifically, their work compiles bond price quotations from a number of primary sources for various state bonds on a daily, weekly, or monthly basis, depending on the frequency with which those bonds traded within the various markets. ${ }^{16}$ This current work employs data from the New York market, as domestic bonds of the time were traded relatively heavily in New York. A second dataset has been incorporated from Dwyer, Hafer and Weber (1999). This database gives weekly bond price data as traded in New York City between 1855 and 1865 for all major states available.

Additionally, to fill in as much missing data as possible after incorporating the two datasets above, I have compiled bond price observations for the New York market between 1850 and 1855. This comes from a number of sources, including The New York Tribune, The New York Times, The Bankers' magazine and Statistical Register and Hunt's Merchants' Magazine and Commercial Review. In all, this current dataset should provide the most comprehensive list of bond prices as they traded in New York between 1850 and 1860.

To investigate the impact that the various state constitutional amendments may have had on a state's bond price, I first analyze the difference-in-averages for three separate cross sectional years in intervals of five years, looking at states that adopted each of the constitutional amendments mentioned above against those states that did not for the years 1850, 1855 and

\footnotetext{
${ }^{15}$ This data is freely available at http://eh.net/databases/early-us-securities-prices.

${ }^{16}$ All bonds traded during this time had a par value of $\$ 100$.
} 
1860. I also include the results for states that defaulted in the sample versus states that did not.

For each of those years I base the dependent variable on the maturity rate for each state's bonds that traded on the New York Stock Exchange for the month of October. ${ }^{17}$ I chose the month of October for a number of reasons. First, all constitutional amendments adopted in 1850 were done so prior to October of that year. Second, for the three cross-sections analyzed, the month of October provides the largest number of data points. Third, over the period from which I pull the data there is very little fluctuation in the price for bonds that were regularly traded; thus I am able to incorporate several relatively less heavily traded state bonds. Table 4.2 provides the results.

Here the results indicate that for those states that adopted a specific constitutional amendment, the average bond price was, indeed, higher than for those states that did not (except for the prohibition on the purchase of stock in 1855 which was only slightly negative, and a time limit on the repayment of a state's debt), averaging from a low of $\$ 1.34$ for states that prohibited the purchase of private stock in 1850 to a high of $\$ 14.12$ for states that restricted the lending of credit in 1850 . Further, states that were able to avoid default generally also saw much higher average bond prices. This result holds for each of the years analyzed, 1850, 1855 and 1860, though the statistical significance seems to dissipate over time. However, the low statistical significance may be a function of low sample size, and thus is still suggestive of economic significance. Specifically, with only twenty-one observations in 1855 representing eleven states and twenty-three observations in 1860 representing seventeen states, this still provides

\footnotetext{
${ }^{17}$ By breaking down each bond by the maturity this allows me to increase what is a relatively low sample size, as some states issued multiple bonds which matured at different times. This also allows me to better account for the inherent risk associated with different bonds as, ceteris paribus, a bond maturing at a later date will be relatively more risky which will thus affect its price. For robustness I will later change this assumption.
} 
Table 4.2: Difference In Averages Results between those states that had imposed or had not imposed the listed constitutional amendments.

\begin{tabular}{|c|c|c|c|c|c|c|}
\hline Year & Amendment & $\begin{array}{c}\text { No Lending } \\
\text { Credit }\end{array}$ & $\begin{array}{c}\text { No Purchasing } \\
\text { Stock } \\
\end{array}$ & $\begin{array}{l}\text { State debt } \\
\text { limits -- } \\
\text { Voting } \\
\text { Procedure } \\
\end{array}$ & $\begin{array}{l}\text { state debt } \\
\text { limits -- time } \\
\text { limits on } \\
\text { repayment }\end{array}$ & Default \\
\hline \multirow{3}{*}{1850} & Average Bond Price for States with the Constitutional Amendment & 102.95 & 101.12 & 107.91 & 105.23 & 88.79 \\
\hline & Average Bond Price for States without the Constitutional Amendment & 89.83 & 99.78 & 96.84 & 96.64 & 104.31 \\
\hline & Difference & $\begin{array}{c}14.12 * * * \\
(2.98) \\
\end{array}$ & $\begin{array}{c}1.34 \\
(0.28) \\
\end{array}$ & $\begin{array}{c}11.06 * * \\
(2.39) \\
\end{array}$ & $\begin{array}{l}8.59^{*} \\
(1.93) \\
\end{array}$ & $\begin{array}{c}-15.51 * * * \\
(3.38) \\
\end{array}$ \\
\hline \multirow{3}{*}{1855} & Average Bond Price for States with the Constitutional Amendment & 102.32 & 99.49 & 102.99 & 104.16 & 95.14 \\
\hline & Average Bond Price for States without the Constitutional Amendment & 93.38 & 100.41 & 97.12 & 94.90 & 102.22 \\
\hline & Difference & $\begin{array}{c}8.94 * * \\
(2.13) \\
\end{array}$ & $\begin{array}{l}-0.92 \\
(0.20) \\
\end{array}$ & $\begin{array}{c}5.87 \\
(1.57) \\
\end{array}$ & $\begin{array}{l}9.26 * * \\
(2.72) \\
\end{array}$ & $\begin{array}{l}-7.07 * \\
(1.73) \\
\end{array}$ \\
\hline \multirow{3}{*}{1860} & Average Bond Price for States with the Constitutional Amendment & 97.73 & 98.04 & 98.67 & 93.45 & 97.64 \\
\hline & Average Bond Price for States without the Constitutional Amendment & 90.81 & 92.69 & 93.73 & 99.48 & 93.62 \\
\hline & Difference & $\begin{array}{l}6.92 * \\
(1.97)\end{array}$ & $\begin{array}{c}5.35 \\
(1.50)\end{array}$ & $\begin{array}{c}4.94 \\
(1.20)\end{array}$ & $\begin{array}{c}-6.03 \\
(1.49)\end{array}$ & $\begin{array}{c}4.02 \\
(0.77)\end{array}$ \\
\hline
\end{tabular}

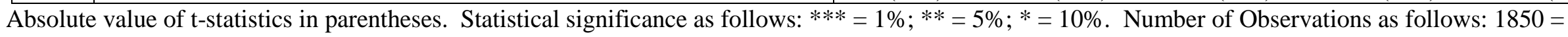
$35 ; 1855=21 ; 1860=23$. 
observations for $54 \%$ and $65 \%$ of all of the states which had any outstanding debt during each of these years respectively. ${ }^{18}$

Given this, as a means to overcome the low sample size problem, I also report a number of cross-sectional pooled OLS regression estimates. The baseline model takes the form:

$$
\text { BondPrice }_{i t}=\alpha+X_{i t}^{\prime} \beta+Z_{i t}^{\prime} \delta+\varphi_{t}+\varepsilon_{i t}
$$

$\mathrm{t}=1850,1855,1860$.

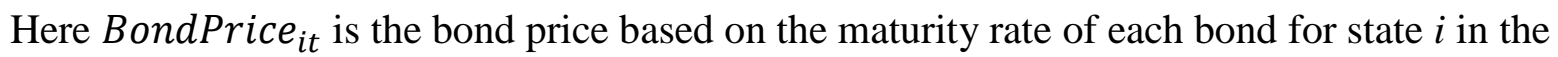
associated year $t$. $X_{i t}^{\prime}$ is a vector of the five explanatory variables discussed above, four of which are the specific constitutional amendments adopted (coded as a 1 if a state had the constitutional amendment and 0 otherwise), while the fifth explanatory variable is whether or not a state defaulted on its debt obligations (again denoted with a 1 if the state defaulted and a 0 otherwise). $Z_{i t}^{\prime}$ is a set of five control variables, to be discussed below, while $\varphi_{t}$ is a time trend dummy variable for each of the years meant to capture any unobserved differences that may emerge between the years under consideration.

One potential issue involved with this analysis is the possibility that the bond price found within the dependent variable may be endogenous to the equation, and thus may actually be explaining some of the independent variables employed. The first best means to overcome this potential problem is through the use of an instrumental variable (IV) and two-stage least squares approach. Unfortunately, the lack of data availability would render a legitimate IV almost impossible to find. However, the historical record suggests that the possibility of any simultaneity bias to be remote for a number of reasons. First, the last state to default was

\footnotetext{
${ }^{18}$ In 1855 there were only 31 states in the Union, growing to 33 by 1860 . Along with this, in 1855 the states of New Hampshire and Wisconsin had negligible debts of $\$ 75,000$ and $\$ 100,000$ respectively making the effective number of states with any substantial debt at 22. In 1860 New Hampshire still only had a negligible debt of \$50,000, leaving the effective number of states with any substantial debt in that year at 25 .
} 
Louisiana in early 1843, while the last state to fully resume payment was Maryland in the summer of 1848. Therefore, although at the time that a state defaulted, it may be the case that a change in bond price may have impacted the probability of defaulting, given that data for the first year employed in this analysis is from 1850, there would, in all likelihood, be no influence. This would also be the case for each of the variables employed for the constitutional amendments. Almost all of the states that passed constitutional amendments did so prior to 1850. For those that did not the only state that may pose some problem would be Pennsylvania (which did not pass any amendments until 1857). For the remaining states, only Kentucky, Virginia, Maryland, Indiana and Ohio had data available for 1850, when any simultaneity issues may be present. However, the historical records show that for four of those states (Kentucky, Maryland, Indiana, and Ohio) both the general vote for a constitutional convention as well as the convention itself happened prior to $1850 .{ }^{19}$ Therefore, given all of this evidence it would appear that the potential for any simultaneity bias is extremely low.

To further minimize the impact that any potential simultaneity bias may create, I have also included a set of five control variables, represented by the vector $Z_{i t}^{\prime}$, which I believe would directly impact the demand for a given state's bonds. First, I control for the number of years left until each bond matures. ${ }^{20}$ As suggested earlier, as the length of time increases before a bond

\footnotetext{
${ }^{19}$ Popular agitation in Maryland began in the early 1840's and was echoed by subsequent governors in their annual messages. Although a constitutional convention wasn't held until 1850, it was largely due to a long-standing debate over the procedural technicalities stipulated in the state's original constitution regarding the amendment process (Harry 1902). Citizens in Indiana voted in favor of a convention in 1848, which received strong support from Governor James Whitcomb in his annual message to the legislature of that year (House Journal of 1848). In Kentucky voters approved a proposed constitutional convention in 1847, which met in October of 1849 and convened in December of that year (Kentucky Legislative Commission 2003). Finally, Ohio voters also voted for a convention in October of 1849 (Smith 1851).

${ }^{20}$ For 9 of the 79 observations there was no distinguishable maturity rate given. Therefore, I assume that each of these bonds matured after 10 years from the first date that data is obtained. For instance, if a state has an unknown maturity on a bond in 1855, I assume a maturity rate of 10 years in 1855 and 5 years in 1860. Although not reported, I considered several other maturity rates for unknown bonds, but found little material change in the results.
} 
matures, the inherent risk associated with that bond should increase. Therefore, I would expect this variable to have a negative impact on a state's bond price.

The second control I include is the coupon or interest rate attached to a bond. Obviously, a bond with an interest rate of $5 \%$ will, ceteris paribus, have a lower price than a bond paying $6 \%$. Therefore, as the interest payment attached to a bond increases so too will its price.

The third control is whether or not a state had a free banking law. This variable is included to proxy for the demand that might be generated by a state's banking industry. As Hunts Merchant's Magazine and Statistical Register reported on March 1, 1848 in regard to New York's free banking law, "The influence of the free banking law, in producing a demand for New York stocks and a consequent rise in prices, has been considerable." Many times states required that before a bank could obtain a charter (whether it be through the legislative process or a free banking law), it had to have a certain amount of collateral on hand in the form of government bonds. Thus, I conjecture that a state with a free banking law would lead to an increase in the demand for bonds, resulting in higher bond prices.

The fourth control variable that I have incorporated is per capita debt. As the amount of debt issued by a state increased, many times it became much more difficult to find ready buyers. This further compounded the ability to readily raise enough revenue through taxation in the event that a state's finances fell upon difficult times. Therefore, I posit that as per capita debt increases it should lead to a decrease in the demand for a state's bonds, resulting in a lower bond price.

Finally, I also include a variable representing the number of years that each of the given states had been a full member of the Union. This variable is meant to proxy for gross state product, as no reliable GSP data exists for the period. I use this because, presumably, the longer 
the state had been a member of the Union, the more developed its economy would have been. Overall, I would expect this variable to have a positive impact on bond prices.

A second model specification that I also consider follows the form

$$
\begin{aligned}
\text { Bondprice }_{i t}= & \alpha+\beta_{1 t} \text { Amendment }_{i t}+\beta_{2 t} \text { Default }_{i t}+\beta_{3 t} \text { Amendment }_{i t} * \text { Default }_{i t} \\
& +Z_{i t}^{\prime} \delta+\varphi_{t}+\varepsilon_{i t}
\end{aligned}
$$

Where, $\beta_{1 t}$ Amendment ${ }_{i t}$ represents each of the amendment variables, $\beta_{2 t}$ De $_{\text {fault }}$ again represents whether a state defaulted and $\beta_{3 t}$ Amendment $_{i t} *$ Default $_{i t}$ is an interaction term between each of the amendment variables. As suggested earlier, I conjecture that for those states that previously defaulted, by constitutionally constraining themselves they correspondingly were able to reenter capital markets more rapidly than otherwise and thus these states benefited relatively more from these amendments than did non-defaulting states. Thus, by including an interaction term, it should pick up whether defaulting states did in fact benefit relatively more in comparison to non-defaulting or non-amending states.

Finally, I also incorporate a set of regressions based on the following equation

$$
\text { Bondprice }_{i t}=\alpha+\beta_{1 t} \text { StringencyIndex }_{i t}+\beta_{2 t} \text { Defualt }_{i t}+Z_{i t}^{\prime} \delta+\varphi_{t}+\varepsilon_{i t}
$$

where the variable StringencyIndex $x_{i t}$ is a variable representing how stringent each of the new constitutional measures that the states adopted was in total. In other words, with this variable each constitutional amendment adopted is given an equal weight of 1 , then to create the index I sum each of those. For example, Kentucky passed three out of four of the constitutional amendments considered in this analysis; therefore the state receives a three on the stringency index (out of a total possible score of four). This final variable may help to capture the 
importance and impact that the aggregate constitutional framework adopted may have had on a state.

\subsubsection{Results and Interpretation}

The pooled OLS regression results also provide striking evidence of the impact that the several constitutional amendments had on bond prices across time. Table 4.3 shows the results assuming a bond's maturity for each state as the dependent variable. Columns 1 through 5 show the results that each individual variable has when run separately against the dependent variable, while column 6 provides the results when all variables are run together. As seen, each of the constitutional amendment variables is positive and highly significant when run separately, suggesting that each amendment increased a state's average bond price by a low of $\$ 5.12$ for strict voting procedures and a high of $\$ 9.80$ for a prohibition on the lending of a state's credit to a private interest, while the default variable has a negative sign coefficient. Further, column 6 again provides the same expected sign predictions (except for the no lending of credit variable, which is negative but statistically insignificant), and also suggests that the two most influential constitutional amendments are restrictions on the purchase of private stock and strict procedural safeguards on issuing debt, increasing bond prices by $\$ 13.91$ and $\$ 9.64$ respectively.

This latter result seems especially relevant, as it acts almost as a two-tiered check on a state's ability to issue debt. In other words, the procedural requirements to change a constitutional amendment are much more costly and time-consuming, generally also requiring a greater than simple majority and majority vote by citizens. Therefore, state legislatures were ex post much more constrained not only in their ability to change the rule allowing them to issue more debt, but also in their ability to issue debt through the everyday political process afterward. Thus, this seems to be the most binding constraint that could be placed, short of an outright 
Table 4.3: Pooled-OLS regression analysis using the average maturity date for each bond by state as the dependent variable.

\begin{tabular}{|c|c|c|c|c|c|c|}
\hline \multirow{2}{*}{$\begin{array}{r}\text { Independent Variable } \\
\text { Constant }\end{array}$} & \multicolumn{6}{|c|}{ Pooled OLS -- Average Maturity Rates as the Dependent Variable } \\
\hline & $33.78 * * *$ & $29.68 * *$ & $36.10 * * *$ & $38.77 * * *$ & $35.42 * * *$ & $34.93 * * *$ \\
\hline \multirow{2}{*}{ No Lending Credit } & $9.80 * * *$ & & & & & -2.13 \\
\hline & $(4.88)$ & & & & & $(0.47)$ \\
\hline No Purchasing Stock & & $8.33 * * *$ & & & & $13.91 * * *$ \\
\hline & & $(3.78)$ & & & & $(3.39)$ \\
\hline \multirow[t]{2}{*}{ State Debt Limits -- Voting Procedure } & & & $5.12 * *$ & & & $9.64 * *$ \\
\hline & & & $(2.18)$ & & & $(2.40)$ \\
\hline \multirow[t]{2}{*}{ State Debt Limits -- Time Limits on Repayment } & & & & $6.54 * * *$ & & 1.41 \\
\hline & & & & $(2.85)$ & & $(0.36)$ \\
\hline \multirow[t]{2}{*}{ Default } & & & & & -0.29 & $-5.12 * *$ \\
\hline & & & & & $(0.10)$ & $(2.04)$ \\
\hline \multirow[t]{2}{*}{ Number of Years Since Achieving Statehood } & $0.44 * * *$ & $0.55 * * *$ & $0.44 * * *$ & $0.36 * * *$ & $0.45^{* * *}$ & $0.49 * * *$ \\
\hline & $(6.68)$ & $(7.46)$ & $(5.83)$ & $(4.46)$ & $(5.44)$ & $(6.08)$ \\
\hline \multirow[t]{2}{*}{ Free Banking Law } & $4.34 * *$ & $4.10 *$ & $5.46^{* *}$ & $7.17 * * *$ & $5.72 * *$ & 3.33 \\
\hline & (2.19) & (1.94) & $(2.48)$ & $(3.25)$ & $(2.52)$ & $(1.52)$ \\
\hline \multirow[t]{2}{*}{ Per Capita Debt } & $-0.49 * * *$ & $-0.66 * * *$ & $-0.31 *$ & $-0.43 * * *$ & $-0.40 *$ & $-0.41 * *$ \\
\hline & $(3.40)$ & $(4.00)$ & (1.85) & $(2.74)$ & (1.97) & $(2.21)$ \\
\hline \multirow[t]{2}{*}{ Years to Maturity } & 0.06 & -0.01 & 0.03 & -0.03 & -0.05 & 0.13 \\
\hline & $(0.60)$ & $(0.14)$ & $(0.26)$ & $(0.23)$ & $(0.45)$ & $(1.18)$ \\
\hline \multirow[t]{2}{*}{ Coupon Rate } & $6.05 * * *$ & $6.88 * * *$ & $6.23 * * *$ & $6.54 * * *$ & $6.85^{* * *}$ & $5.28^{* * *}$ \\
\hline & $(3.57)$ & $(1.78)$ & $(3.26)$ & $(3.53)$ & $(3.47)$ & $(3.19)$ \\
\hline R-Squared & 0.538 & 0.453 & 0.416 & 0.467 & 0.378 & 0.585 \\
\hline Observations & 79 & 79 & 79 & 79 & 79 & 79 \\
\hline Time Fixed Effects & $\mathrm{Y}$ & $\mathrm{Y}$ & $\mathrm{Y}$ & Y & $\mathrm{Y}$ & $\mathrm{Y}$ \\
\hline
\end{tabular}

Absolute value of t-statistics in parentheses. Statistical significance as follows: $* * *=1 \%$; $* *=5 \%$; $*$ $10 \%$.

prohibition on any debt issue, and therefore potentially one of the most credible for markets.

This is especially true given that most state legislatures were simultaneously required to pass appropriations bills meant to raise the necessary revenue to pay off the principal once the debt was incurred. Overall, the results are fairly clearly indicating that each constitutional restriction increased a state's average bond price once passed.

Next, I analyze the results from equation (2), found in table 4.4. Here again, the results do by-and-large suggest that defaulting states that subsequently constitutionally constrained 
themselves did benefit more than non-defaulting states. Except for a restriction on stock ownership, all of the other interaction terms are positive, with a low of $\$ 3.00$ for a restriction on the lending of credit to private interests and a high of $\$ 17.08$ for strict requirements on the repayment of debt. This again suggests that amendments regarding procedural restraints on the legislature and also on the ability to issue debt allowed previously defaulting states to more rapidly obtain favorable credit and bond prices. These results also help to support those in table 3, and suggest that more rigorous and costly voting procedures not only limited the ability to issue debt, but also sent the necessary signal of credibility to potential creditors.

Next, for robustness I analyze the data from several other perspectives. The first takes as the dependent variable the average bond price based on the interest paid for each bond. For example, a state may have placed three separate bonds on the market, two paying $5 \%$ interest and one paying $6 \%$ issued in 1850 , which due to the differing interest payments would have led to a different bond price. Thus, following my new procedure I would have two observations for that state, one for the $6 \%$ issue and one for the average price of the $5 \%$ issue. $^{21}$ The results are provided in table 4.5. As can be seen these results are extremely similar to those found initially in table 4.3. For each individual variable, the constitutional amendments are all positive and significant, with a low of $\$ 7.51$ for the prohibition on the purchase of stock and a high of $\$ 9.43$ for the restriction on the lending of a state's credit to private interests. When run together, as in column 6 , the results again are strikingly similar to those of table 4.3 , with both the restriction on the purchase of stock and strict voting procedures as having the greatest impact, increasing a state's bond price by $\$ 12.34$ and $\$ 11.99$ respectively.

\footnotetext{
${ }^{21}$ Obviously manipulating the dependent variable in this manner would require a similar manipulation of the variables for length to maturity and the coupon rate. Therefore, when multiple bond prices are averaged together I simultaneously average the years to maturity and coupon rate for those observations.
} 
Table 4.4: Pooled-OLS interaction regression analysis using the average maturity date for each bond by state as the dependent variable.

\begin{tabular}{|c|c|c|c|c|}
\hline Independent Variables & \multicolumn{4}{|c|}{ Pooled OLS -- Average Maturity Rates as the Dependent Variable } \\
\hline Constant & $\begin{array}{c}35.29 * * * \\
(3.04)\end{array}$ & $\begin{array}{c}33.49 * * * \\
(2.75)\end{array}$ & $\begin{array}{c}37.08 * * * \\
(2.94)\end{array}$ & $\begin{array}{c}41.93 * * * \\
(3.59)\end{array}$ \\
\hline No Lending Credit & $\begin{array}{c}9.17 * * * \\
(3.80)\end{array}$ & & & \\
\hline No Lending Credit x Default & $\begin{array}{c}3.00 \\
(0.68)\end{array}$ & & & \\
\hline No Purchasing Stock & & $\begin{array}{c}10.05 * * * \\
(3.44)\end{array}$ & & \\
\hline No Purchasing Stock x Default & & $\begin{array}{l}-2.28 \\
(0.49)\end{array}$ & & \\
\hline State Debt Limits -- Voting Procedure & & & $\begin{array}{c}2.35 \\
(0.89)\end{array}$ & \\
\hline State Debt Limits -- Voting Procedure x Default & & & $\begin{array}{c}13.27 * * \\
(2.18)\end{array}$ & \\
\hline State Debt Limits -- Time Limits on Repayment & & & & $\begin{array}{c}2.38 \\
(1.00)\end{array}$ \\
\hline State Debt Limits -- Time Limits on Repayment x Default & & & & $\begin{array}{c}17.08 * * * \\
(3.77)\end{array}$ \\
\hline Default & $\begin{array}{l}-4.00 \\
(1.04)\end{array}$ & $\begin{array}{l}-2.23 \\
(0.64)\end{array}$ & $\begin{array}{l}-2.85 \\
(1.00)\end{array}$ & $\begin{array}{l}-4.38^{*} \\
(1.63)\end{array}$ \\
\hline Number of Years Since Achieving Statehood & $\begin{array}{c}0.43^{* * *} \\
(5.75)\end{array}$ & $\begin{array}{c}0.53 * * * \\
(6.70)\end{array}$ & $\begin{array}{c}0.53 * * * \\
(5.70)\end{array}$ & $\begin{array}{c}0.37 * * * \\
(4.65)\end{array}$ \\
\hline Free Banking Law & $\begin{array}{c}4.52 * * \\
(2.26)\end{array}$ & $\begin{array}{l}3.80 * \\
(1.74)\end{array}$ & $\begin{array}{l}5.07 * * \\
(2.34)\end{array}$ & $\begin{array}{c}8.70 * * * \\
(4.19)\end{array}$ \\
\hline Per Capita Debt & $\begin{array}{c}-0.41 * * \\
(2.33)\end{array}$ & $\begin{array}{c}-0.55 * * * \\
(2.92)\end{array}$ & $\begin{array}{l}-0.29 \\
(1.45)\end{array}$ & $\begin{array}{c}-0.66^{* * *} \\
(3.52)\end{array}$ \\
\hline Years to Maturity & $\begin{array}{c}0.04 \\
(0.40)\end{array}$ & $\begin{array}{l}-0.01 \\
(0.11)\end{array}$ & $\begin{array}{c}0.02 \\
(0.19)\end{array}$ & $\begin{array}{l}-0.07 \\
(0.66)\end{array}$ \\
\hline Coupon Rate & $\begin{array}{c}5.99 * * * \\
(3.44)\end{array}$ & $\begin{array}{c}6.39 * * * \\
(3.49) \\
\end{array}$ & $\begin{array}{c}5.32 * * * \\
(2.75) \\
\end{array}$ & $\begin{array}{c}6.45^{* * *} \\
(3.74) \\
\end{array}$ \\
\hline R-Squared & 0.544 & 0.476 & 0.407 & 0.550 \\
\hline Observations & 79 & 79 & 79 & 79 \\
\hline Time Fixed Effects & $\mathrm{Y}$ & $\mathrm{Y}$ & $\mathrm{Y}$ & $\mathrm{Y}$ \\
\hline
\end{tabular}

Absolute value of t-statistics in parentheses. Statistical significance as follows: $* * *=1 \%$; $* *=5 \%$; $*$ $10 \%$.

I also provide the results from Equation (2) for the interaction terms using this new independent variable as well, found in table 4.6. As with table 4.4, the results presented here are 
Table 4.5: Pooled-OLS regression analysis using the average interest rates paid on each bond by state as the dependent variable.

\begin{tabular}{|c|c|c|c|c|c|c|}
\hline Independent Variable & \multicolumn{6}{|c|}{ Pooled OLS -- Average Interest Rate as the Dependent Variable } \\
\hline Constant & $\begin{array}{c}37.21 * * \\
(2.51)\end{array}$ & $\begin{array}{c}37.04 * * \\
(2.34)\end{array}$ & $\begin{array}{c}37.69^{* *} \\
(2.39)\end{array}$ & $\begin{array}{c}40.89 * * \\
(2.60)\end{array}$ & $\begin{array}{c}36.04 * * \\
(2.03)\end{array}$ & $\begin{array}{c}44.52 * * * \\
(2.93)\end{array}$ \\
\hline No Lending Credit & $\begin{array}{c}9.43 * * * \\
(3.61)\end{array}$ & & & & & $\begin{array}{l}-0.55 \\
(0.10)\end{array}$ \\
\hline No Purchasing Stock & & $\begin{array}{l}7.51 * * \\
(2.42)\end{array}$ & & & & $\begin{array}{c}12.34 * * \\
(2.42)\end{array}$ \\
\hline State Debt Limits -- Voting Procedure & & & $\begin{array}{c}8.09 * * \\
(2.54)\end{array}$ & & & $\begin{array}{c}11.99 * * \\
(2.29)\end{array}$ \\
\hline State Debt Limits -- Time Limits on Repayment & & & & $\begin{array}{l}8.17 * * \\
(2.66)\end{array}$ & & $\begin{array}{l}-0.61 \\
(0.12)\end{array}$ \\
\hline Default & & & & & $\begin{array}{c}1.03 \\
(0.29)\end{array}$ & $\begin{array}{l}-5.16 \\
(1.48)\end{array}$ \\
\hline Number of Years Since Achieving Statehood & $\begin{array}{c}0.40 * * * \\
(5.03)\end{array}$ & $\begin{array}{c}0.48 * * * \\
(5.34)\end{array}$ & $\begin{array}{c}0.41 * * * \\
(4.78)\end{array}$ & $\begin{array}{c}0.32 * * * \\
(3.48)\end{array}$ & $\begin{array}{c}0.43 * * * \\
(4.20)\end{array}$ & $\begin{array}{c}0.45 * * * \\
(4.56)\end{array}$ \\
\hline Free Banking Law & $\begin{array}{l}5.03 * \\
(1.93)\end{array}$ & $\begin{array}{c}4.41 \\
(1.54)\end{array}$ & $\begin{array}{c}5.89 * * \\
(2.14)\end{array}$ & $\begin{array}{c}8.14 * * * \\
(2.87)\end{array}$ & $\begin{array}{l}6.06^{* * *} \\
(2.04)\end{array}$ & $\begin{array}{c}3.34 \\
(1.12)\end{array}$ \\
\hline Per Capita Debt & $\begin{array}{c}-0.48 * * \\
(2.47)\end{array}$ & $\begin{array}{c}-0.55^{* *} \\
(2.50)\end{array}$ & $\begin{array}{l}-0.27 \\
(1.34)\end{array}$ & $\begin{array}{l}0.39 * \\
(1.96)\end{array}$ & $\begin{array}{l}-0.39 \\
(1.53)\end{array}$ & $\begin{array}{l}-0.36 \\
(1.62)\end{array}$ \\
\hline Years to Maturity & $\begin{array}{c}0.11 \\
(0.75)\end{array}$ & $\begin{array}{c}0.03 \\
(0.20)\end{array}$ & $\begin{array}{c}0.15 \\
(0.85)\end{array}$ & $\begin{array}{l}-0.01 \\
(0.10)\end{array}$ & $\begin{array}{l}-0.02 \\
(0.15)\end{array}$ & $\begin{array}{l}0.30^{*} \\
-1.65\end{array}$ \\
\hline Coupon Rate & $\begin{array}{l}5.36^{* *} \\
(2.29)\end{array}$ & $\begin{array}{l}5.69 * * \\
(2.27)\end{array}$ & $\begin{array}{c}5.31 * * \\
(2.11)\end{array}$ & $\begin{array}{l}5.95 * * \\
(2.41)\end{array}$ & $\begin{array}{l}6.43 * * \\
(2.37)\end{array}$ & $\begin{array}{c}3.19 \\
(1.30)\end{array}$ \\
\hline R-Squared & 0.537 & 0.460 & 0.473 & 0.486 & 0.395 & 0.601 \\
\hline Observations & 53 & 53 & 53 & 53 & 53 & 53 \\
\hline Time Fixed Effects & $\mathrm{Y}$ & $\mathrm{Y}$ & $\mathrm{Y}$ & $\mathrm{Y}$ & $\mathrm{Y}$ & $\mathrm{Y}$ \\
\hline
\end{tabular}

Absolute value of t-statistics in parentheses. Statistical significance as follows: $* * *=1 \%$; $* *=5 \%$; $*$ $10 \%$.

almost identical. Further, it would again appear that both a strict voting procedure and a strict timeframe on the repayment of debt were the most significant restrictions on a previously defaulting state in a post-default world, both having the largest impact on a state's recovery after such a default as opposed to those states that did not impose similar restrictions.

As a final cut of the data I also take the overall average bond price for each state. Under this assumption I end up with one observation for each of the states in each of the given years. ${ }^{22}$

\footnotetext{
${ }^{22}$ Again I average both the coupon and maturity rate variables in a fashion to reflect this change in the dependent variable.
} 
Table 4.6: Pooled-OLS interaction regression analysis using the average interest rates paid on each bond by state as the dependent variable.

\begin{tabular}{|c|c|c|c|c|}
\hline Independent Variables & \multicolumn{4}{|c|}{ Pooled OLS -- Average Interest Rate as the Dependent Variable } \\
\hline \multirow{2}{*}{ Constant } & $38.31 * *$ & $42.99 * *$ & $37.84 * *$ & $44.13 * * *$ \\
\hline & $(2.40)$ & $(2.51)$ & $(2.32)$ & $(2.80)$ \\
\hline \multirow[t]{2}{*}{ No Lending Credit } & $8.52 * *$ & & & \\
\hline & $(2.68)$ & & & \\
\hline \multirow[t]{2}{*}{ No Lending Credit x Default } & 3.99 & & & \\
\hline & $(0.73)$ & & & \\
\hline \multirow[t]{2}{*}{ No Purchasing Stock } & & $11.23 * *$ & & \\
\hline & & $(2.37)$ & & \\
\hline \multirow[t]{2}{*}{ No Purchasing Stock x Default } & & -5.14 & & \\
\hline & & $(0.82)$ & & \\
\hline \multirow[t]{2}{*}{ State Debt Limits -- Voting Procedure } & & & 4.31 & \\
\hline & & & $(1.16)$ & \\
\hline \multirow[t]{2}{*}{ State Debt Limits -- Voting Procedure x Default } & & & $12.74 *$ & \\
\hline & & & $(1.87)$ & \\
\hline \multirow[t]{2}{*}{ State Debt Limits -- Time Limits on Repayment } & & & & 3.96 \\
\hline & & & & $(1.19)$ \\
\hline \multirow[t]{2}{*}{ State Debt Limits -- Time Limits on Repayment x Default } & & & & $15.20 * *$ \\
\hline & & & & $(2.60)$ \\
\hline \multirow[t]{2}{*}{ Default } & -4.08 & -0.74 & -1.90 & -2.86 \\
\hline & $(0.85)$ & $(0.17)$ & $(0.54)$ & $(0.82)$ \\
\hline \multirow[t]{2}{*}{ Number of Years Since Achieving Statehood } & $0.40 * * *$ & $0.46^{* * *}$ & $0.51 * * *$ & $0.34 * * *$ \\
\hline & $(4.25)$ & $(4.68)$ & $(4.76)$ & $(3.56)$ \\
\hline \multirow[t]{2}{*}{ Free Banking Law } & $5.20 *$ & 3.84 & $5.29 *$ & $8.69 * * *$ \\
\hline & $(1.96)$ & $(1.29)$ & $(1.93)$ & $(3.20)$ \\
\hline \multirow[t]{2}{*}{ Per Capita Debt } & $-0.41 *$ & $-0.50 * *$ & -0.30 & $-0.55 * *$ \\
\hline & $(1.83)$ & $(2.04)$ & $(1.27)$ & $(2.44)$ \\
\hline \multirow[t]{2}{*}{ Years to Maturity } & 0.08 & 0.07 & 0.10 & -0.07 \\
\hline & $(0.50)$ & $(0.40)$ & $(0.60)$ & $(0.45)$ \\
\hline \multirow[t]{2}{*}{ Coupon Rate } & $5.35^{* *}$ & $4.77 *$ & $4.66^{*}$ & $5.75 * *$ \\
\hline & $(2.17)$ & $(1.79)$ & $(1.83)$ & $(2.41)$ \\
\hline R-Squared & 0.542 & 0.478 & 0.492 & 0.554 \\
\hline Observations & 53 & 53 & 53 & 53 \\
\hline Time Fixed Effects & $\mathrm{Y}$ & $\mathrm{Y}$ & $\mathrm{Y}$ & $\mathrm{Y}$ \\
\hline
\end{tabular}

Absolute value of t-statistics in parentheses. Statistical significance as follows: $* * *=1 \%$; $* *=5 \%$; $=$ $10 \%$.

As can be seen, when compared with both table 3 and 5, these results are extremely similar and support those previously found. Each of the individual constitutional amendments has a positive and significant sign coefficient, with a low of $\$ 7.21$ for a voting procedure and a high of $\$ 9.71$ 
Table 4.7: Pooled-OLS regression analysis using the average bond price for each state as the dependent variable.

\begin{tabular}{|c|c|c|c|c|c|c|}
\hline Independent Variable & \multicolumn{6}{|c|}{ Pooled OLS -- Average Bond Prices as the Dependent Variable } \\
\hline \multirow[t]{2}{*}{ Constant } & $36.34 *$ & 32.45 & $42.42 * *$ & $41.30 *$ & 31.46 & $56.11 * *$ \\
\hline & $(1.97)$ & $(1.58)$ & $(2.10)$ & $(2.04)$ & $(1.32)$ & $(2.73)$ \\
\hline \multirow[t]{2}{*}{ No Lending Credit } & $9.79 * * *$ & & & & & 3.12 \\
\hline & $(3.71)$ & & & & & $(0.59)$ \\
\hline \multirow[t]{2}{*}{ No Purchasing Stock } & & $7.21 * *$ & & & & $9.62 *$ \\
\hline & & $(2.15)$ & & & & $(1.93)$ \\
\hline \multirow[t]{2}{*}{ State Debt Limits -- Voting Procedure } & & & $9.43 * *$ & & & $10.93 *$ \\
\hline & & & $(2.64)$ & & & $(1.94)$ \\
\hline \multirow[t]{2}{*}{ State Debt Limits -- Time Limits on Repayment } & & & & $8.49^{* *}$ & & -2.06 \\
\hline & & & & $(2.56)$ & & $(0.39)$ \\
\hline \multirow[t]{2}{*}{ Default } & & & & & 0.95 & -6.51 \\
\hline & & & & & $(0.818)$ & $(1.65)$ \\
\hline \multirow[t]{2}{*}{ Number of Years Since Achieving Statehood } & $0.41 * * *$ & $0.46 * * *$ & $0.41 * * *$ & $0.33 * * *$ & $0.42 * * *$ & $0.43 * * *$ \\
\hline & $(5.12)$ & $(4.98)$ & $(4.78)$ & $(3.56)$ & $(3.84)$ & $(4.25)$ \\
\hline \multirow[t]{2}{*}{ Free Banking Law } & 4.01 & 3.89 & $5.10 *$ & $7.68 * *$ & $5.88 *$ & 1.91 \\
\hline & $(1.51)$ & $(1.27)$ & $(1.79)$ & $(2.64)$ & $(1.86)$ & $(0.60)$ \\
\hline \multirow[t]{2}{*}{ Per Capita Debt } & $-0.58 * * *$ & $-0.60 * *$ & $-0.38^{*}$ & $-0.50 * *$ & $-0.47 *$ & $-0.40^{*}$ \\
\hline & $(3.02)$ & $(2.68)$ & $(1.84)$ & $(2.42)$ & $(1.76)$ & $(1.80)$ \\
\hline \multirow[t]{2}{*}{ Years to Maturity } & -0.01 & -0.07 & 0.18 & -0.14 & -0.08 & 0.18 \\
\hline & $(0.07)$ & $(0.37)$ & $(0.81)$ & $(0.70)$ & $(0.35)$ & $(0.76)$ \\
\hline \multirow[t]{2}{*}{ Coupon Rate } & $6.26 * *$ & $7.23 * *$ & 4.71 & $6.57 *$ & $7.79 * *$ & 2.09 \\
\hline & $(2.09)$ & $(2.18)$ & $(1.39)$ & $(2.02)$ & $(2.12)$ & $(0.61)$ \\
\hline \multirow{2}{*}{ R-Squared } & 0.617 & 0.523 & 0.551 & 0.537 & 0.452 & 0.683 \\
\hline & 41 & 41 & 41 & 41 & 41 & 41 \\
\hline $\begin{array}{r}\text { Observations } \\
\text { Time Fixed Effects }\end{array}$ & $\mathrm{Y}$ & $\mathrm{Y}$ & $\mathrm{Y}$ & $\mathrm{Y}$ & $\mathrm{Y}$ & $\mathrm{Y}$ \\
\hline
\end{tabular}

Absolute value of t-statistics in parentheses. Statistical significance as follows: $* * *=1 \%$; $* *=5 \%$; $*$ $10 \%$.

for a restriction on the lending of credit to private interests. As before, when regressed together, the two most significant variables are a restriction on the purchase of private stock and a voting procedural safeguard, each increasing average bond prices by $\$ 9.62$ and $\$ 10.93$ respectively.

Again, I also run a set of regressions using this new dependent variable with the interaction terms listed in Equation (2). These results are found in table 4.8. As before, these results conform to those found in tables 4 and 6 . Overall, all of the results taken together would suggest that these constitutional amendments almost across the board increased each state's bond 
prices after they were enacted. Each seems to have had a significant impact, greatly improving a state's overall debt and thus a state's fiscal position. What's more, defaulting states that enacted strict voting procedures as well as time limits on the repayment of interest and principal were able to recover more rapidly relative to those states that did not.

Finally, table 4.9 provides the results from equation (3). Columns 1 and 2 provide the results when the dependent variable is based on the maturity rate for the bonds of each state. Columns 3 and 4 assume the dependent variable is the average interest payment on each bond by state, while columns 5 and 6 assume the total average bond price for each state as the dependent variable. Overall, the results are all positive and significant. Specifically, based on the dependent variable used, with each additional constitutional constraint imposed by a state its bond price increases anywhere from a low of $\$ 3.78$ to a high of $\$ 4.20$. Thus, a state with all four constitutional constraints can expect a bond price that is roughly $\$ 16$ higher than a state that did not adopt any of the constraints. Further, the interaction term also suggests that as previously defaulted states adopted more constitutional constraints, their circumstances improve relatively more rapidly as compared to non-defaulting states and states that did not impose similar constraints.

Given everything observed within the empirical analysis, it would suggest that constitutional constraints imposed by both defaulting and non-defaulting states may have in fact acted as credible commitments to bondholders going into the future. Given all of this evidence presented it would appear that bondholders took as most credible those constitutional constraints that limited stock ownership and imposed strict voting procedures on legislative bodies that were required to issue debt. Further, defaulting states, post-default, saw the most rapid increase in their bond prices as a result of imposing strict voting safeguards and also limiting the maturity 
Table 4.8: Pooled-OLS interaction regression analysis using the average bond price for each state as the dependent variable.

\begin{tabular}{|c|c|c|c|c|}
\hline Independent Variables & \multicolumn{4}{|c|}{ Pooled OLS -- Average Bond Prices } \\
\hline \multirow[t]{2}{*}{ Constant } & $40.12 *$ & $43.27 *$ & $45.80 * *$ & $46.44 * *$ \\
\hline & (1.99) & $(1.86)$ & $(2.11)$ & $(2.15)$ \\
\hline \multirow[t]{2}{*}{ No Lending Credit } & $8.48^{* * *}$ & & & \\
\hline & $(2.73)$ & & & \\
\hline \multirow[t]{2}{*}{ No Lending Credit x Default } & 7.50 & & & \\
\hline & $(1.41)$ & & & \\
\hline \multirow[t]{2}{*}{ No Purchasing Stock } & & $11.04 * *$ & & \\
\hline & & $(2.06)$ & & \\
\hline \multirow[t]{2}{*}{ No Purchasing Stock x Default } & & -3.82 & & \\
\hline & & $(0.57)$ & & \\
\hline \multirow[t]{2}{*}{ State Debt Limits -- Voting Procedure } & & & 5.55 & \\
\hline & & & $(1.35)$ & \\
\hline \multirow[t]{2}{*}{ State Debt Limits -- Voting Procedure x Default } & & & $12.08^{*}$ & \\
\hline & & & $(1.82)$ & \\
\hline \multirow[t]{2}{*}{ State Debt Limits -- Time Limits on Repayment } & & & & 4.88 \\
\hline & & & & $(1.32)$ \\
\hline \multirow{2}{*}{ State Debt Limits -- Time Limits on Repayment x Default } & & & & $12.46^{*}$ \\
\hline & & & & $(2.00)$ \\
\hline \multirow[t]{2}{*}{ Default } & -8.06 & -2.65 & -2.41 & -3.82 \\
\hline & $(1.63)$ & $(0.52)$ & $(0.62)$ & $(0.92)$ \\
\hline \multirow[t]{2}{*}{ Number of Years Since Achieving Statehood } & $0.39 * * *$ & $0.43^{* * *}$ & $0.49 * * *$ & $0.23 * * *$ \\
\hline & $(4.22)$ & $(4.14)$ & $(4.64)$ & $(3.17)$ \\
\hline \multirow[t]{2}{*}{ Free Banking Law } & 4.2 & 3.42 & 4.48 & $8.11 * * *$ \\
\hline & (1.59) & $(1.07)$ & (1.58) & $(2.82)$ \\
\hline \multirow[t]{2}{*}{ Per Capita Debt } & $-0.46^{* *}$ & $-0.52 * *$ & -0.38 & $-0.54 * *$ \\
\hline & $(2.10)$ & $(2.05)$ & $(1.60)$ & $(2.29)$ \\
\hline \multirow[t]{2}{*}{ Years to Maturity } & -0.11 & -0.10 & 0.14 & -0.23 \\
\hline & $(0.60)$ & $(0.43)$ & $(0.61)$ & $(1.10)$ \\
\hline \multirow[t]{2}{*}{ Coupon Rate } & $6.12 *$ & 5.76 & 3.63 & $6.23 *$ \\
\hline & $(1.95)$ & $(1.59)$ & $(1.03)$ & $(1.89)$ \\
\hline R-Squared & 0.651 & 0.539 & 0.594 & 0.592 \\
\hline Observations & 41 & 41 & 41 & 41 \\
\hline Time Fixed Effects & $\mathrm{Y}$ & $\mathrm{Y}$ & $\mathrm{Y}$ & $\mathrm{Y}$ \\
\hline
\end{tabular}

Absolute value of t-statistics in parentheses. Statistical significance as follows: $* * *=1 \% ; * *=5 \%$; $*$ $10 \%$.

period on outstanding debt. This latter amendment would presumably reduce the inherent risk associated with longer-term debt, and thus provide a more reasonable timeframe for creditors to assess the potential risk associated with sovereign default. 
Table 4.9: Pooled-OLS regression analysis using the constitutional stringency index.

\begin{tabular}{|c|c|c|c|c|c|c|}
\hline Independent Variable & \multicolumn{2}{|c|}{ Average Maturity } & \multicolumn{2}{|c|}{ Average Interest } & \multicolumn{2}{|c|}{ Average Price } \\
\hline Constant & $\begin{array}{c}37.68 * * * \\
(3.32)\end{array}$ & $\begin{array}{c}36.58 * * * \\
(3.28)\end{array}$ & $\begin{array}{c}41.85^{* * *} \\
(2.75)\end{array}$ & $\begin{array}{c}41.25 * * * \\
(2.76)\end{array}$ & $\begin{array}{c}50.64 * * \\
(2.54)\end{array}$ & $\begin{array}{c}50.41 * * \\
(2.64)\end{array}$ \\
\hline Stringency Index & $\begin{array}{c}3.78 * * * \\
(5.22)\end{array}$ & $\begin{array}{c}2.84 * * * \\
(3.29)\end{array}$ & $\begin{array}{c}3.98^{* * *} \\
(4.14)\end{array}$ & $\begin{array}{l}3.00^{* *} \\
(2.63)\end{array}$ & $\begin{array}{c}4.20^{* * *} \\
(4.16)\end{array}$ & $\begin{array}{c}3.10^{* * * *} \\
(2.77)\end{array}$ \\
\hline Stringency Index Interaction & & $\begin{array}{l}3.01 * \\
(1.94)\end{array}$ & & $\begin{array}{c}2.95 \\
(1.56)\end{array}$ & & $\begin{array}{l}3.52 * \\
(1.94)\end{array}$ \\
\hline Default & $\begin{array}{l}-2.32 \\
(0.96)\end{array}$ & $\begin{array}{c}-7.10^{* *} \\
(2.08)\end{array}$ & $\begin{array}{l}-2.00 \\
(0.64)\end{array}$ & $\begin{array}{l}-6.54 \\
(1.55)\end{array}$ & $\begin{array}{l}-3.86 \\
(1.10)\end{array}$ & $\begin{array}{c}-9.67^{* *} \\
(2.15)\end{array}$ \\
\hline Years Since Achieving Statehood & $\begin{array}{c}0.39 * * * \\
(5.44)\end{array}$ & $\begin{array}{c}0.43 * * * \\
(5.86)\end{array}$ & $\begin{array}{c}0.37 * * * \\
(4.19)\end{array}$ & $\begin{array}{c}0.41 * * * \\
(4.52)\end{array}$ & $\begin{array}{c}0.36 * * * \\
(3.98)\end{array}$ & $\begin{array}{c}0.39 * * * \\
(4.46)\end{array}$ \\
\hline Free Bank & $\begin{array}{c}5.18^{* * * *} \\
(2.67)\end{array}$ & $\begin{array}{c}5.79 * * * \\
(3.01)\end{array}$ & $\begin{array}{l}5.79 * * \\
(2.29)\end{array}$ & $\begin{array}{c}6.04 * * \\
(2.42)\end{array}$ & $\begin{array}{l}4.83 * \\
(1.87)\end{array}$ & $\begin{array}{l}4.99 * \\
(2.02)\end{array}$ \\
\hline Per Capita Debt & $\begin{array}{c}-0.39 * * \\
(2.29)\end{array}$ & $\begin{array}{c}-0.44 * * \\
(2.59)\end{array}$ & $\begin{array}{l}-0.42 * \\
(1.95)\end{array}$ & $\begin{array}{c}-0.43^{* *} \\
(2.03)\end{array}$ & $\begin{array}{c}-0.47 * * \\
(2.20)\end{array}$ & $\begin{array}{c}-0.47 * * \\
(2.26)\end{array}$ \\
\hline Years to Maturity & $\begin{array}{c}0.08 \\
(0.75)\end{array}$ & $\begin{array}{c}0.03 \\
(0.30)\end{array}$ & $\begin{array}{c}0.15 \\
(0.98)\end{array}$ & $\begin{array}{c}0.08 \\
(0.50)\end{array}$ & $\begin{array}{l}-0.01 \\
(0.04)\end{array}$ & $\begin{array}{l}-0.11 \\
(0.60)\end{array}$ \\
\hline Coupon Rate & $\begin{array}{c}5.66^{* * * *} \\
(3.34) \\
\end{array}$ & $\begin{array}{c}5.87 * * * \\
(3.52)\end{array}$ & $\begin{array}{l}4.65^{*} \\
(1.98) \\
\end{array}$ & $\begin{array}{c}4.79 * * \\
(2.07) \\
\end{array}$ & $\begin{array}{c}4.13 \\
(1.32) \\
\end{array}$ & $\begin{array}{c}4.32 \\
(1.45) \\
\end{array}$ \\
\hline R-Squared & 0.563 & 0.563 & 0.573 & 0.587 & 0.649 & 0.689 \\
\hline Observations & 79 & 79 & 53 & 53 & 41 & 41 \\
\hline Time Fixed Effects & $\mathrm{Y}$ & $\mathrm{Y}$ & $\mathrm{Y}$ & $\mathrm{Y}$ & $\mathrm{Y}$ & $\mathrm{Y}$ \\
\hline
\end{tabular}

Absolute value of t-statistics in parentheses. Statistical significance as follows: $* * *=1 \%$; $* *=5 \%$; $*$ $=10 \%$.

Along with this, those states willing to adopt additional constraints were able both to see more rapidly improved bond prices and to obtain higher bond prices relative to states that were either unwilling or unable to more strictly constrain themselves. Overall, this seems to have made it possible for states to resume the financing of public projects at more reasonable rates, lessening both the debt burden and obligations on those respective states and citizens. Further, it would appear that those constitutional constraints acted as an "over-commitment," meant to more strongly convey credibility into the future relative to those states that did not enact such constraints. Although states could have simply statutorily bound themselves, the response by creditors to those states that self imposed more rigorous constraints suggests this "overcommitment" did in fact have its desired effect. 
Finally, these results may provide an interesting analysis for the unfolding events that have emerged today both internationally and domestically. As noted, the prediction market InTrade has opened markets trading on the event that the states of New York, Illinois and California were to default. Interestingly, an analysis of each of these states shows they were some of the first to adopt not only several of the constitutional restrictions outlined above, but to also still have those amendments today. The question then becomes, how it is possible that even with these constitutional amendments intact today, these states have accrued as much debt as they have and have been deemed as risky as they are? An analysis of each of the current constitutional provisions suggests slow erosion of those original constitutional restrictions over time. Although a detailed analysis of each of these constitutions is beyond the scope of this current work, a simple word count is quite revealing.

For California the original amendments included in the state's constitution consumed 324 words; however the section of the state's current constitution dealing with public finance is now 1,644 words. For Illinois, the original constitution had 370 words devoted to public finance, but today that number stands at 568 words. Finally, the original amendments to New York's constitution in regard to public finance and debt contained 1,841 words, whereas today it is 2,395. Most significant, the majority of the changes appear to specifically amend the limits on and ability to incur debt.

Further, Spain in order to cope with its own fiscal problems passed a balanced budget amendment to its constitution and some similar discussion has recently emerged in the United States. Although neither sovereign has yet to default, the debts that both have incurred have become a major policy issue. If the previous results provide any potential implications for today, it may be the possible importance of stricter voting procedures as a means to limit and constrain 
a sovereign from overextending credit. Some type of increased legislative majority and/or popular vote would increase the political cost associated with increasing a sovereign nation's debt and thus potentially may slow the accumulation of debt and help to improve sovereign fiscal positions. Although many of these current issues are beyond the scope of this work, they may provide areas of future research.

\subsection{Conclusion}

The U.S. state debt crisis of the early 1840s was an extremely acute episode. Though painful, it was relatively short-lived. After the smoke had settled, eight states and one territory had defaulted, several others came extremely close to defaulting, and five states either entirely or partially repudiated their debts. Shortly after this episode, many states passed constitutional amendments or adopted completely new constitutions, all of which had numerous clauses pertaining specifically to state credit.

This study has attempted to understand why this may have been the case. Specifically, I have argued that these amendments were a means by which states attempted to send a signal of future credibility to capital markets and thus to reenter those markets on more favorable terms. Given the results that I have obtained, there is strong evidence to suggest that these binding constraints did have a positive impact on creditors' perceptions of the individual state governments. States that constitutionally constrained themselves to specific rules regarding the issuing and financing of public debt saw significant increases in their average bond prices. However, it would also appear that although eventually all defaulting and repudiating states were able to reenter capital markets, for those without constitutional changes (even once repayment on 
portions of outstanding debt began), it was much more difficult and costly for them to either reenter credit markets or issue new debt.

Although this episode in American economic history has been studied at length from various aspects, few have considered this as a potential explanation for the state response that emerged. As such, this work has suggested an entirely new reason that states may have selfimposed the constitutional constraints that they did: as a means to convey a credible commitment to the future repayment of all debt obligations in a post-default world and simultaneously to constrain all future governments from overextending credit. 


\section{Chapter 5}

\section{Conclusion}

\subsection{Concluding Remarks and Areas of Future Research}

This dissertation has attempted to study a number of components within the legal framework under the U.S. system of federalism. Specifically it has analyzed differences within the law between the states, with two chapters devoted to differences at the sub-constitutional level and the final chapter looking at differences within the constitutional framework. Each of these chapters have shown the importance that the law and legal institutions play in economic outcomes and also how even minor differences in these institutions can lead to radically different economic outcomes across the states.

The analysis from chapter 2 shows how the incentives created by state antitrust law lead to a certain set of outcomes from the state officials responsible with enforcing those laws: the state attorney general (AG). In particular, the findings suggest that there has been a marked changed between the relative costs and benefits of not only undertaking antitrust enforcement actions over time, but also of running for the office of state AG and higher office as well. Given this, the chapter provided empirical evidence showing exactly the type of impact this change in the costs and benefits have been.

Overall, the estimates suggest that state AGs will be less likely to undertake in-state antitrust actions during elections, but will be much more likely to participate in multistate actions during those same elections. Further, state AGs with parens patriae authority are also far more likely to initiate antitrust actions that eventually become multistate cases as well. These results have real implications for both policy and possible future research. 
Specifically, these results suggest that state antitrust enforcement may be much more politically motivated than it is based on the criteria of economic efficiency. This has an important effect: it directly conflicts with federal antitrust enforcement, and the guidelines by which federal agencies (the Department of Justice and Federal Trade Commission) pursue antitrust action. Whereas these two agencies pursue enforcement actions that will enhance economic and allocative efficiency in order to enhance national economic growth, state antitrust enforcement by-and-large pursues policy geared toward much narrower interests. Given that one of the most important tenants of the rule of law is predictability in its enforcement, such conflicting policy goals between state and federal antitrust enforcement create greater uncertainty throughout the economy and potentially discourage growth and investment.

Given this outcome there may be room to develop a much more coherent antitrust policy which better defines the proper scope that each governmental unit (state or federal) should play in enforcing antitrust law. Here the implications seem clear, either state or federal policy needs to be realigned and a more coherent set of guidelines must be created, or enforcement should be left largely to the federal authorities. As enforcement stands it creates the incentive for overenforcement (especially with the potential spillover effects it creates between states), and thus an inefficiently large number of antitrust actions being pursued. Further, given the political incentives involved, state AGs have a much stronger incentive to pursue actions that may be politically beneficial rather than economically relevant.

Within this framework, there is also opportunity to pursue further research in order to better understand some of the state-level issues at hand. For instance, little work has been done to study the economic impact that parens patriae has. Although the evidence I find suggests that parens patriae does impact the decision to pursue some antitrust actions, it is surprising that the 
results are as ambiguous as they are. Thus, a more systematic study of that specific power may net more interesting and robust conclusions regarding its actual importance in political decision making. Further, there is also room for research to study how state antitrust enforcement impacts specific industries within a state or across the country. This may better help to understand to what extent state enforcement may actually be based on economic and allocative efficiency versus some other type of non-economic motivation.

The third chapter provided an entirely new area within which to apply the process of entrepreneurial creative destruction. I suggest that through entrepreneurial creative destruction a process of legal creative destruction is set in motion as a result. This is due to the fact that entrepreneurs both desire and require new laws and legal precedent in order to account for the new entrepreneurial activities that they pursue and create. In this light, through a system of horizontal federalism, states compete with one another and as a result create comparative advantages within specific niches of the legal market.

In this framework, entrepreneurs will, at the margin, attempt to shed as much legal risk as they can and will locate to those jurisdictions in which the process of legal creative destruction will emerge and evolve in the most predictable manner through time. Numerous examples of the phenomena exist including Florida regarding maritime law and Delaware regarding corporate law, just to name two.

Again, this research provides both a number of policy implications and potential avenues to pursue future research. In regard to policy, this chapter suggests that interjurisdictional competition creates an incentive for states to create these legal markets, and that it will simultaneously minimize the amount of unproductive entrepreneurship which emerges within a state. Thus, contrary to a large amount of rhetoric, simply driving rulemaking decisions up a 
level (to the federal government) and leaving the creation of law in the hands of a single governmental unit may be suboptimal. This may be the case as with only a single governmental unit creating law in this manner, it increases the potential for suboptimal path dependence which will actually reduce economic well-being and will lead to more rigid legal institutions that are more difficult to abolish once it is discovered that they truly are suboptimal in this respect. Thus, providing greater autonomy to junior level governments increases legal competition and helps to foster this process of legal creative destruction.

One significant area of future research worth pursuing is how this process affects both productive and unproductive entrepreneurship. Although the issue is addressed briefly in the chapter, it is by no means exhaustive of the possible avenues to pursue. One specific area is to better understand exactly the mechanism by which unproductive entrepreneurship will be minimized while productive maximized. An interesting question to address is to what extent unproductive entrepreneurship is actually minimized. Another potentially interesting avenue is to examine how this process of legal creative destruction may differ within a country or jurisdiction that does not operate under a system of federalism in order to better draw out the implications I have suggested.

Finally, chapter 4 provided an empirical investigation of the response to the sovereign debt crisis of 1839-1842. After a series of sovereign defaults and repudiations a number of U.S. states passed constitutional amendments meant to constrain those same state governments from pursuing similar behavior in the future. Simultaneously, they were meant to signal a credible recommitment to credit markets that state governments would again pursue time-consistent public policy. The results of this analysis were clear: states that constitutionally constrained themselves from overextending debt burdens and from avoiding investments in a number of private projects 
were able to reenter capital markets more rapidly than states that did not, and were also able to obtain credit at much more favorable rates.

Overall, the policy implications are clear for both domestic and international governments, especially today in the wake of the recent financial crisis. Specifically, a set of binding, constitutional rules may be what is most needed in order to quiet markets and to return sovereign governments to fiscal stability and soundness. Thus, a binding balanced budget amendment to the constitution of not just the U.S. but also sovereign states (such as Greece) may set the necessary course for future stability resulting in growth and economic expansion. It may also help to reduce both sovereign debt and deficit through time and avoid what may eventually emerge as a more severe shock to the economy, especially in the event that a sovereign state like the U.S. were to default. 


\section{References}

Acemoglu, Daron and Johnson, Simon. (2005). "Unbundling Institutions." Journal of Political Economy. 113(5): 949-994.

Acemoglu, Daron; Johnson, Simon; and Robinson, James. (2001). "The ColonialOrigins of Comparative Development: An Empirical Investigation.” American Economic Review. 91(5): 1369-1401.

Acemoglu, Daron; Johnson, Simon; and Robinson, James. (2002). "Reversal of Fortune: Geography and Institutions in the Making of the Modern World income Distribution." Quarterly Journal of Economics. 117(4): 1231-1294.

The Bankers' Magazine and Statistical Register. Various Issues.

Barro, Robert and Gordon, D.B. (1983). “A Positive Theory of Monetary Policy in a Natural-Rate Model.” Journal of Political Economy. 91(4), 589-610.

Baumol, William J. (1990). “Entrepreneurship: Productive, Unproductive, and Destructive.” The Journal of Political Economy. 98(5): 893-921.

Bebchuk, Lucian. (1992). "Federalism and the Corporation: The Desirable Limits on State Competition in Corporate Law." Harvard Law Review. 105(7): 1435-1510.

Bebchuk, Lucian and Cohen, Alma. (2003). “Firm’s Decisions when to Incorporate.” Journal Of Law and Economics. 46(2): 383-425.

Bebchuk, Lucian; Cohen, Alma and Ferrell, Allen. (2002). "Does the Evidence Favor Sate Competition in Corporate Law?” California Law Review. 90(6): 1775-1821.

Bender, Bruce and Lott, John R. Jr. (1996). "Legislative Voting and Shirking: A Critical Review of the Literature." Public Choice. 87(1-2): 67-100.

Beyle, Thad and Jensen, Jennifer M. Gubernatorial Campaign Expenditures Database. 
Various Years.

Bratton, William A. and McCahery, Joseph A. (1997). “The New Economics of Jurisdictional Competition: Devolutionary Federalism in a Second-Best World.” Georgetown Law Journal. 86(2): 201-278.

Buchanan, James M. (1975). The Limits of Liberty: Between Anarchy and Leviathan. University of Chicago Press.

Butler, Henry and Macey, Jonathan. (1988). "The Myth of Competition in the Dual Banking System.” Cornell Law Review. 73(4): 677-713.

Cary, William L. (1974). “Federalism and Corporate Law: Reflections upon Delaware.” Yale Law Journal. 83(4): 663-705.

Clayton, Cornell (1994). "Law, Politics and the New Federalism: State Attorneys General as National Policy Makers.” The Review of Politics. 56(3): 525-553.

Council of State Governments. The Book of the States (Lexington, KY). Various Years.

Curtis, B.A. (1844). "Debts of the States.” The North American Review. 58(122), 109157.

Diamond, Doug. (1989). "Reputation Acquisition in Debt Markets.” The Journal of Political Economy. 97(4), 828-862.

DeBow, Michael. (2004). "State Antitrust Enforcement: Empirical Evidence and a Modest Reform Proposal." In Competition Laws in Conflict: Antitrust Jurisdiction in the Global Economy. Ed. Richard A. Epstein. AEI Press.

Djankov, Simeon; La Porta, Rafael; Lopez-de-Silanes, Florencio and Shleifer, Andrei. (2003). “Courts.” Quarterly Journal of Economics. 118(2): 453-517.

Dwyer, Gerald P. Jr.; Hafer, R.W. and Weber, Warren E. (1999). "Weekly U.S. and State Bond Prices, 1855-1865." Historical Methods. 32(1), 37-42. 
Easterbrook, Frank H. (1983). "Antitrust and the Economics of Federalism." Journal of Law and Economics. 26(1): 23-50.

Elkins, Zachary; Ginsburg, Tom and Melton, James. (2009). The Endurance of National Constitutions. New York: Cambridge University Press.

Farmer, Susan Beth. (1999). "More Lessons from the Laboratories: Cy Pres Distributions in Parens Patriae Antitrust Actions Brought by State Attorneys General.” Fordham Law Review. 68(2): 361-406.

Flexner, Donald L. and Racanelli, Mark A. (1993-1994). "State and Federal Antitrust Enforcement in the United States: Collision or Harmony?" Connecticut Journal Of International Law. Vol. 9, pg. 501-534.

Frye, Timothy. (2004). “Credible Commitments and Property Rights: Evidence from Russia." The American Political Science Review. 98(3), 453-466.

Frye, Timothy and Shleifer, Timothy. (1997). "The Invisible Hand and the Grabbing Hand." The American Economic Review. 87(2): 354-358.

Galie, Peter J. (1991). The New York State Constitution: A Reference Guide. Westport CT: Greenwood Publishing Group.

Garten, Helen A. (1996). "Devolution and Deregulation: The Paradox of Financial Reform.” Yale Law and Policy Review. 14(1): 65-97.

Gifford, Donald G. (2008). "Impersonating the Legislature: State Attorneys General and Parens Patriae Product Litigation.” Boston College Law Review. 49(4): 913-969. Glaeser, Edward and Shleifer, Andrei. (2002). "Legal Origins.” Quarterly Journal of Economics. 117(4): 1193-1229. 
Goodrich, Carter. (1950). “The Revulsion Against Internal Improvements.” The Journal of Economic History, 10(2), 145-169.

Greve, Michael S. (2005). “Cartel Federalism? Antitrust Enforcement by State

Attorneys General.” The University of Chicago Law Review. 72(1): 99-122.

Harmon, Robert B. (1991). State Attorneys General: A Bibliography and Survey.

Vance Bibliographies: Public Administration Series.

Harry, James Warner. (1902). “The Maryland Constitution of 1851.” In J.M. Vincent, J.H.

Hollander And W.W. Willough (Ed.),_Johns Hopkins University Studies in Historical and Political Science (pp. 387-464). Baltimore: The Johns Hopkins Press.

Hayek, Friedrich. (1945). "The Use of Knowledge in Society." The American Economic Review. 35(4): 519-530.

Hayek, Friedrich. (1960). The Constitution of Liberty. The University of Chicago Press.

Herrick, Rebekah and Moore, Michael K. (1993). “Political Ambition's Effect on Legislative Behavior: Schlesinger's Typology Reconsidered and Revisited." Journal of Politics. 55(3): 765-776.

Hunt's Merchants' Magazine and Commercial Review. Various Issues.

Ieyoub, Richard P. and Eisenberg, Theodore. (2000). "State Attorney General Actions, The Tobacco Litigation, and the Doctrine of Parens Patriae." Tulane Law Review. 74(5-6), 1847-1858.

Inman, Robert P. and Rubinfeld, Daniel L. (1997). "Rethinking Federalism.” Journal of Economic Perspectives. 11(4): 43-64.

Journal of the House of Representatives of the State of Indiana. Various Years. Indianapolis, Indiana: John D. Defrees. 
Journal of the Senate of the Commonwealth of Kentucky. (1848). Frankfort, Kentucky: A.G. Hodges and Company.

Journal of Proceedings of the House of Delegates of the State of Maryland. (1840).

Annapolis, Maryland: George T. Melvin.

Journal of the Senate of the State of New York. (1846). Albany, New York: E. Mack.

Kentucky Legislative Research Commission (2003). Constitutional Background. Kentucky Government Informational Bulletin, No. 137 (Revised).

http://www.Irc.ky.gov/lrcpubs/IB137.pdf. Accessed September 1, 2011.

Kim, Namsuk and Wallis, John Joseph. (2005). “ The Market for American State Government Bonds in Britain and the United States, 1830-43." Economic History Review. 58(4), 736-764.

Kirzner, Israel M. (1978). Competition and Entrepreneurship. The University of Chicago Press: Chicago.

Kirzner, Israel M.. (1997). “Entrepreneurial Discovery and the Competitive Market Process: An Austrian Approach.” Journal of Economic Literature. 35(1): 60-85.

Knight, Frank H. (1921[2005]). Risk, Uncertainty and Profit. Cosino Inc. New York, New York.

Konisky, David M. (2007). "Regulatory Competition and Environmental Enforcement: Is there A Race to the Bottom?" American Journal of Political Science. 51(4): 853-872.

Konisky, David M.. (2010). "Public Preferences for Environmental Policy Responsibility.” Publius: The Journal of Federalism. 41(1): 76-100.

Konisky, David M. and Woods, Neil D. (2009). “Exporting Air Pollution? Regulatory 
Enforcement and Environmental Free Riding in the United States.” Political Research Quarterly. 63(4): 771-782.

Kubik, Jeffrey D. and Moran, John R. (2003). "Lethal Elections: Gubernatorial Politics And the Timing of Executions." Journal of Law and Economics. 46(1): 1-25. Kydland, Finn E. and Prescott, Edward C. (1977). "Rules Rather than Discretion: The Inconsistency of Optimal Plans.” The Journal of Political Economy, 85(3), 473- 492.

La Porta, Rafael; Lopez-de-Silanes; Pop-Eleches, Cristian and Shleifer, Andrei. (2004). “Judicial Checks and Balances.” Journal of Political Economy. 112(2): 445-470.

La Porta, Rafael; Lopez-de-Silanes, Florencio; Shleifer, Andre and Vishney, Robert. (1999). "The Quality of Government." Journal of Law, Economics and Organization. 15(1): 222-279.

Lemos, Margaret H. (2011). “State Enforcement of Federal Law.” New York University Law Review. Forthcoming.

Lynch, Jason. (2001). “Federalism, Separation of Powers, and the Role of State Attorneys General in Multi-state Litigation.” Columbia Law Review. 101(8): 1998-2032.

Marshall, William P. (2006). "Break up the Presidency? Governors, State Attorneys General, and Lessons from the Divided Executive." The Yale Law Journal. 115(9): 2446-2479.

McGrane, Reginald C. (1933). "Some Aspects of American State Debts in the Forties." The American Historical Review, 38(4), 673-686.

McGrane, Reginald C. (1965). The Panic of 1837. New York: Russell and Russell Inc. 
McQuillan, Lawrence J. and Abramyan, Hovannes. (2010). U.S. Tort Liability Index: 2010 Report. Pacific Research Institute. San Francisco, California.

Morris, Thomas. (1986). "States before the U.S. Supreme Court: State Attorneys General as amicus curiae." Judicature. 70: 298-305.

Myers, Emily and Ross, Lynne ed. (2008). State Attorneys General Powers and

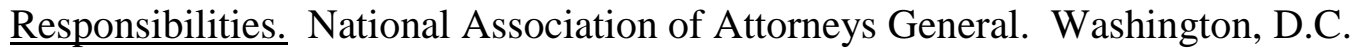
Second Edition.

Myerson, R.B. (2007). "Foundations of the State in Theory and Practice: Reading Bremer and The Counterinsurgency Field Manual.” Mimeo, Department of Economics: University of Chicago.

The New York Times. Various Issues

The New York Tribune. Various Issues

North, Douglass C. (1990). Institutions, Institutional Change and Economic Performance. Cambridge University Press.

North, Douglass C. (1991). "Institutions." The Journal of Economic Perspectives. 5(1),97112.

North, Douglass C., and Weingast, Barry R. (1989). “Constitutions and Commitment: The Evolution of Institutions Governing Public Choice in Seventeenth Century England.” Journal of Economic History, 49(4), 803-832.

Oates, Wallace E. (2001). “A Reconsideration of Environmental Federalism.” Resources for The Future Discussion Paper 01-54.

Posner, Richard. (2004). "Federalism and the Enforcement of Antitrust Laws by State Attorneys General.” The Georgetown Journal of Law \& Public Policy. 2(5): 5-16. 
Porter, Robert P. (1880). "State Debts and Repudiation.” The International Review, 9(1), 556604.

Priest, George L. (1977). “The Common Law Process and the Selection of Efficient Rules." The Journal of Legal Studies. 6(1): 65-82.

Provost, Colin. (2003). "State Attorneys General, Entrepreneurship, and Consumer Protection in the New Federalism." Publius: The Journal of Federalism. 33(2): 37-53.

Provost, Colin. (2006). “The Politics of Consumer Protection: Explaining State Attorney General Participation in Multi-State Lawsuits." Political Research Quarterly. 59(4): 609-618.

Provost, Colin. (2010). "When is AG Short for Aspiring Governor? Institutional Structure, Policy Making Dynamics and Ambition in the Office of State Attorney General.” Publius: The Journal of Federalism. 40(4): 569-596.

Ratchford, B.U. (1941). American State Debts. Durham: Duke University Press. Ray, Leonard and Spill, Rorie. (2002). “The States in Federal Appellate Court: Litigation Trends Over Time.” The Justice System Journal. 23(1): 97.

Revesz, Richard L. (1996). "Federalism and interstate Environmental Externalities." University of Pennsylvania Law Review. 144(6): 2341-2416.

Revesz, Richard L. (1997). "Federalism and Environmental Regulation. A Normative Critique." In John Ferejohn and Barry R. Weingast, eds. The New Federalism: Can the

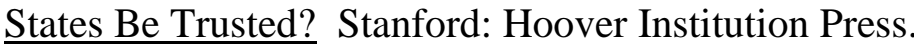

Rodrick, Dani. (1989). “Promises, Promises: Credible Policy Reform via Signaling.” The Economic Journal. 99(397), 756-772. 
Romano, Roberta. (1985). "Law as Product: Some pieces of the Incorporation Puzzle." Journal of Law, Economics and Organization. 1(2): 225-283.

Scott, Kenneth E. (1977). “The Dual Banking System: A Model of Competition in Regulation.” Stanford Law Review. 30(1): 1-50.

Scott, William A. (1893). The Repudiation of State Debt. Thomas Y. Crowell \& Company: New York.

Schumpeter, Joseph A. (1934[2007]). The Theory of Economic Development. Transaction Publishers. New Brunswick, New Jersey.

Schumpeter, Joseph A. (1942[2003]). Capitalism, Socialism and Democracy. George Allen and Unwin Ltd.

Smith, J.V. (1851). Report of the Debates and Proceedings of the Convention for the Revision Of the Constitution of the State of Ohio. Columbus, Ohio: S. Medary.

Smith, Joseph and Tiller, Emerson. (2002). "The Strategy of Judging: Evidence from Administrative Law." Journal of Legal Studies. 31(1): 61-82.

Sobel, Russell S. (2008). “Testing Baumol: Institutional Quality and the Productivity of Entrepreneurship." Journal of Business Venturing. 23(6): 641-655.

Spill, Rorie; Licari, Michael; and Ray, Leonard. (2001). "Taking on Tobacco: Policy Entrepreneurship and the Tobacco Litigation.” Political Research Quarterly 54(3): 605622

Stuart, Richard B. (1977a). "The Development of Administrative and Quasi-Constitutional Law in Judicial Review of Environmental Decisionmaking: Lessons from the Clean Air Act.” Iowa Law Review. 62(3): 713-769. 
Stuart, Richard B. (1977b). "Pyramids of Sacrifice? Problems of Federalism in Mandating State Implementation of National Environmental Policy." Yale Law Journal. 86(6): 1196-1272.

Sylla, Richard E.; Wilson, Jack and Wright, Robert E. (2006). "Price Quotations in Early U.S. Securities Markets, 1790-1860.” http://eh.net/databases/early-us-securities-prices. Accessed September 1, 2011

Tiebout, Charles M. (1956). “A Pure Theory of Local Expenditures.” The Journal of Political Economy. 64(5): 416-424.

Wallis, John Joseph. (2000). “American Government Finance in the Long Run: 1790 to 1990.” The Journal of Economic Perspectives. 14(1), 61-82.

Wallis, John Joseph. (2001). "What Caused the Crisis of 1839?” NBER Historical Paper No. 133.

Wallis, John Joseph. (2005). “Constitutions, Corporations, and Corruption: American States and Constitutional Change, 1842 to 1852." The Journal of Economic History. 65(1), 211-256.

Wallis, John Joseph; Sylla, Richard E.; and Grinath, Arthur. (2004). "Sovereign Debt and Repudiation: The Emerging Market Debt Crisis in the U.S. States, 1839-1843.” NBER Working Papers Series, W-10753.

Waltenburg, Eric and Swinford, Bill. (1999). “The Supreme Court as a Policy Arena: The Strategies and Tactics of State Attorneys General.” Policy Studies Journal. 27(2): 242259. 
Weingast, Barry R. (1993). “Constitutions as Governance Structures: The Political Foundations of Secure Markets.” Journal of Institutional and Theoretical Economics. 149(1), 286311.

Weingast, Berry R. (1995). “The Economic Role of Political Institutions: MarketPreserving Federalism and Economic Development." Journal of Law, Economics and Organization. 11(1): 1-31.

Wibbels, Erik. (2003). "Bailouts, Budget Constraints, and Leviathans: Comparative Federalism and Lessons from the Early United States.” Comparative Political Studies. 36(5), 475508.

Zimmerman, Joseph F. (1998). "Interstate Cooperation: The Roles of the State Attorneys General." Publius: The Journal of Federalism. 28(1): 71-89.

Zunnernabm Joseph F. (1999). "Why State Attorneys General Should have a Limited Role in Enforcing the Federal Antitrust Law of Mergers." Emory Law Journal. 39(1): 305336.

Zupan, Mark A. (1990). “The Last Period Problem in Politics: Do Congressional Representatives not Subject to a Reelection Constraint Alter Their Voting Behavior?" Public Choice. 65(1-2): 167-180. 